\title{
Site U1421
}

\author{
J.M. Jaeger, S.P.S. Gulick, L.J. LeVay, H. Asahi, H. Bahlburg, C.L. Belanger, G.B.B. Berbel, L.B. Childress, \\ E.A. Cowan, L. Drab, M. Forwick, A. Fukumura, S. Ge, S.M. Gupta, A. Kioka, \\ S. Konno, C.E. März, K.M. Matsuzaki, E.L. McClymont, A.C. Mix, C.M. Moy, J. Müller, A. Nakamura, \\ T. Ojima, K.D. Ridgway, F. Rodrigues Ribeiro, O.E. Romero, A.L. Slagle, J.S. Stoner, \\ G. St-Onge, I. Suto, M.H. Walczak, and L.L. Worthington ${ }^{2}$
}

\section{Chapter contents}

Background and objectives........... 1

Operations.....................

Lithostratigraphy.................

Paleontology and biostratigraphy .......6

Stratigraphic correlation............ 7

Geochemistry ............... 8

Physical properties ............. 11

Paleomagnetism ................ 14

Downhole logging . . . . . . . . . . 14

Core-log-seismic integration. . . . . . . . . . 17

References...................... 18

Figures.................... 21

Tables....................63

1Jaeger, J.M., Gulick, S.P.S., LeVay, L.J., Asahi, H., Bahlburg, H., Belanger, C.L., Berbel, G.B.B., Childress, L.B., Cowan, E.A., Drab, L., Forwick, M., Fukumura, A., Ge, S., Gupta, S.M., Kioka, A., Konno, S., März, C.E., Matsuzaki, K.M., McClymont, E.L., Mix, A.C., Moy, C.M., Müller, J., Nakamura, A., Ojima, T., Ridgway, K.D., Rodrigues Ribeiro, F., Romero, O.E., Slagle, A.L.,Stoner, J.S., St-Onge, G., Suto, I., Walczak, M.H., and Worthington, L.L., 2014. Site U1421. In Jaeger, J.M., Gulick, S.P.S., LeVay, L.J., and the Expedition 341 Scientists, Proc. IODP, 341: College Station, TX (Integrated Ocean Drilling Program). doi:10.2204/iodp.proc.341.107.2014

'Expedition 341 Scientists' addresses.

\section{Background and objectives}

A primary objective of Expedition 341 was to examine the impact of changing Neogene sedimentation rates on actively deforming orogenic structures. Whereas Site U1420 targeted strata above an inactive thrust fault, Site U1421 was positioned to sample correlative strata on the limb of an actively deforming structure, where more deeply buried seismic sequences on the shelf are observed slightly closer to the seafloor. Site U1421 is located downslope of the Bering Trough above the youngest two thrusts of the Pamplona Zone where they cut obliquely across the slope (Fig. F1B). The slope sediments trapped behind these folds are seismically reflective, and sequences within them are mappable onto the shelf. These sequences appear to aggrade through Horizon H1 roughly parallel with the modern slope surface and include thinned distal extents of shelf sedimentary sequences, as well as slope sequences that are correlative with sequences truncated by unconformity Horizon H1 (Fig. F2). Shallower than Horizon H1, the slope sequence is more uniform in thickness and includes higher amplitude reflections that may represent the formation of a glacial trough mouth fan associated with the arrival of glacier termini at the shelf edge during glacial maxima, which is suggested to have initiated during the mid-Pleistocene transition (Fig. F2) (Berger et al., 2008).

At the southeastern end of the STEEP09 seismic profile (Fig. F1A), two active faults (BT1 and BT2) are present at the continental slope, exhibiting less burial than the structures on the shelf. Scarps $\sim 750$ and $\sim 300 \mathrm{~m}$ high associated with the active slope structures are visible on high-resolution bathymetry of the continental slope (Worthington et al., 2008). Site U1421 is located just landward of Fault BT2, which may have initiated after the Pliocene-Pleistocene transition (Worthington et al., 2010), given the lack of growth strata observed below Horizon H3 (Fig. F1). The presence of two distinct sedimentary packages on Fault BT2 is indicative of either a decrease in slope sedimentation or an increase in deformation rate across Fault BT2. Between Horizons H1 and $\mathrm{H} 2$, the angle of the observed growth strata becomes less pronounced, indicating a gradual decrease in fault growth rate during the early-Middle Pleistocene (Worthington et al., 2010) or an increase in accumulation rate. Shallower than Horizon H1, sediments are truncated by the anticline and are very slightly tilted toward the shelf, indicating either minimal deformation on 
Fault BT2 since Horizon H1 or high accumulation rates.

The target depth at this site was designed to penetrate Reflector H2 (expected to lie at $\sim 1 \mathrm{~km}$ ), which is mapped from the shelf where it marks the latest growth strata associated with a now inactive thrust fault (Figs. F1A, F2). Determining the age of this reflector (hypothesized to be younger than the Pliocene/Pleistocene boundary) will allow us to infer the timing of when loading by increasing sediment accumulation forced accommodation of collisional stresses to be shifted elsewhere in the orogen (Worthington et al., 2010). Crossing the slope equivalent of the angular unconformity Horizon $\mathrm{H} 1$ will occur while drilling to the depth of Horizon $\mathrm{H} 2$, allowing for a second opportunity beyond Site U1420 to constrain the timing of its formation. Potential lithofacies are alternating diamict (ice-rafted debris and debris flow deposits), turbidites, and hemipelagic mud (Fig. F3). This site is expected to provide a proximal provenance record of sediment supply from the Bering Glacier, which can be used to locate the temporal and spatial loci of glacial erosion in the St. Elias orogen.

\section{Operations}

\section{Transit to Site U1421}

After an $11.9 \mathrm{nmi}$ transit from Site U1420 averaging $7.9 \mathrm{kt}$, the vessel arrived at the final expedition site. The vessel stabilized over Site U1421 at $0235 \mathrm{~h}$ (UTC $-8 \mathrm{~h}$ ) on 22 July 2013, and the positioning beacon was deployed at $0245 \mathrm{~h}$.

\section{Site U1421}

Site U1421 consists of three holes (Table T1). Hole U1421A was cored to $702.7 \mathrm{~m}$ drilling depth below seafloor (DSF) using a combination of the advanced piston corer (APC) and extended core barrel (XCB) systems. Hole U1421B was cored to $6.2 \mathrm{~m}$ DSF. Hole U1421C was cored to $38.2 \mathrm{~m}$ DSF. Total time spent on Site U1421 was 154.25 h (6.43 days).

A total of 92 cores were recorded for the site. The APC system was deployed 26 times. The XCB system was deployed 66 times. A total of 26 APC cores were collected over $140.8 \mathrm{~m}$, with $114.47 \mathrm{~m}$ recovered $(81 \%)$. A total of $66 \mathrm{XCB}$ cores were drilled over $606.3 \mathrm{~m}$, with $61.54 \mathrm{~m}$ recovered (10\%). The overall recovery for Site U1421 was 23.6\% (Fig. F4).

\section{Hole U1421A}

Hole U1421A was spudded at $0730 \mathrm{~h}$ on 22 July 2013. The mudline core recovered $6.82 \mathrm{~m}$ of sedi- ment, and the seafloor was calculated to be at 718.5 meters below sea level (mbsl). All piston cores were tide corrected at the drill down before each core was shot. Nonmagnetic core barrels and the APC system were used for Cores 341-U1421A-1H through $8 \mathrm{H}$, and FlexIT orientation was performed on Cores $2 \mathrm{H}$ through $8 \mathrm{H}$. Cores $9 \mathrm{H}$ through $19 \mathrm{H}$ were recovered using the half APC coring system with steel core barrels. Partial APC strokes were recorded on Cores $6 \mathrm{H}$, $8 \mathrm{H}$ through $10 \mathrm{H}, 13 \mathrm{H}$ through $16 \mathrm{H}, 18 \mathrm{H}$, and $19 \mathrm{H}$. The APC cores were affected by frequently encountered large clasts, several of which prevented recovery. The XCB system was deployed with a soft-formation cutting shoe for Cores 20X through 64X. On Core $65 \mathrm{X}$, the cutting shoe was changed to the hardformation carbide-tipped shoe. Coring continued through Core 85X (702.7 m DSF). Total depth was reached at $1825 \mathrm{~h}$ on 26 July.

A total of $360 \mathrm{bbl}$ of high-viscosity mud was used to clean the hole during coring operations. The hole was displaced with $50 \mathrm{bbl}$ of high-viscosity mud followed by $328 \mathrm{bbl}$ of $11.8 \mathrm{ppg}$ heavy mud for logging. After displacing the hole with heavy mud, the trip out of the hole was performed while fighting high rotational torque on the fifth single of drill pipe. Torque became minimal at $391.8 \mathrm{~m} \mathrm{DSF}$, and the top drive was set back. The drill string was then pulled back, and the end of the pipe was set at $96.6 \mathrm{~m}$ DSF. A modified logging tool string termed the Sonicinduction tool string, measuring gamma ray, borehole diameter, sonic velocity, and resistivity, was run to $699 \mathrm{~m} \mathrm{DSF}$, and two passes were made. The logging string was then pulled back to surface and rigged down at $0845 \mathrm{~h}$ on 27 July.

The Versatile Seismic Imager (VSI) tool string was rigged up and run into the hole. Protective Species Observation watches began at $0700 \mathrm{~h}$. No protected marine species were observed during this period within the $1410 \mathrm{~m}$ diameter exclusion zone for this site, so the seismic source (a parallel cluster of two 250 inch $^{3}$ Sercel G. Guns) was ramped up starting $1 \mathrm{~h}$ after the watches commenced. Watches continued throughout the VSI run, with guns fired manually as the tool string was run into the hole. Once the VSI tool string was in the hole, firing control was delivered to the Schlumberger engineer. After tagging bottom, the tool was positioned at the first station. Nine stations were attempted with successful measurements recorded at six stations (see "Downhole logging"). The tool was then pulled out of the hole to the surface and rigged down at $1630 \mathrm{~h}$ on 27 July. The guns were secured, and Protective Species Observation watches ceased after the last station was completed. At the conclusion of logging, the circulating head was removed, the knobbies were set back, and 
the drill string was pulled from the hole to just above the seafloor. The bit cleared the seafloor at $1715 \mathrm{~h}$ on 27 July, ending Hole U1421A.

A total of 19 APC cores were taken over a $96.4 \mathrm{~m}$ interval, with $79.18 \mathrm{~m}$ recovered $(82 \%)$. A total of 66 $\mathrm{XCB}$ cores were cut over a $606.3 \mathrm{~m}$ interval, with $61.54 \mathrm{~m}$ recovered (10\%). The overall core recovery for Hole U1421A was $140.72 \mathrm{~m}$ for the $702.7 \mathrm{~m}$ cored interval (20.0\%). Total time spent on Hole U1421A was $134.75 \mathrm{~h}$.

\section{Hole U1421B}

After clearing the seafloor, the vessel was moved 28.3 $\mathrm{m}$ southwest of Hole U1421A. Hole U1421B was spudded at $1925 \mathrm{~h}$ on 27 July 2013 . The mudline core recovered $6.23 \mathrm{~m}$ of sediment, and seafloor was calculated to be 722.7 mbsl. Coring in Hole U1421B was terminated at a total depth of $6.2 \mathrm{~m}$ DSF at 1925 h on 27 July, after the stratigraphic correlators confirmed that the piston core shoot depth was incorrect. One piston core was taken over a $6.2 \mathrm{~m}$ interval, with $6.23 \mathrm{~m}$ recovered (101\%). Total time spent on Hole U1421B was $2.25 \mathrm{~h}$.

\section{Hole U1421C}

After clearing the seafloor, the vessel was offset $20 \mathrm{~m}$ west of Hole U1421B. Hole U1421C was spudded at $2005 \mathrm{~h}$ on 27 July 2013 . The mudline core recovered $8.57 \mathrm{~m}$ of sediment, and the seafloor was calculated to be at $721.8 \mathrm{mbsl}$. All piston cores were tide corrected at the drill down before each core was shot. Nonmagnetic core barrels and the APC system were used for Cores $341-\mathrm{U} 1421 \mathrm{C}-1 \mathrm{H}$ through $4 \mathrm{H}$. Cores $5 \mathrm{H}$ and $6 \mathrm{H}$ were recovered using the half APC coring system to $38.2 \mathrm{~m}$ DSF. Temperature measurements were taken with the advanced piston corer temperature tool (APCT-3) on Cores $4 \mathrm{H}$ and $6 \mathrm{H}$. Coring in Hole U1421C was terminated when the core barrel for Core $6 \mathrm{H}$ became stuck in the bottom-hole assembly (BHA). After shearing off the core barrel, the sinker bars were retrieved and the drill string was tripped clear of the seafloor with the top drive installed. The top drive was then set back, and the drill string was tripped to surface. The BHA was set back in the derrick, and the core barrel was removed and laid out. The BHA was then tripped back into the hole, and each drill collar was pulled up and laid out in the forward drill collar racks. The rig floor was secured at $1230 \mathrm{~h}$ on 28 July. The thrusters were then raised, and the vessel began the transit to Valdez, Alaska (USA), at $1245 \mathrm{~h}$, ending Site U1421. A total of six APC cores were taken over a $38.2 \mathrm{~m}$ interval, with $29.06 \mathrm{~m}$ recovered $(76 \%)$. Total time spent on Hole U1421C was $18.0 \mathrm{~h}$.

\section{Lithostratigraphy}

Lithologic summaries of the three holes drilled at Site U1421 are shown in Figure F5. The sediment recovered at Site U1421 contains nine facies. Detailed facies descriptions, information about common marine microfossils, facies occurrence in lithostratigraphic units, and tentative interpretations about depositional environments are summarized in Table T2. The dominant facies (F1a, F1b, F4e, and F4f) are dark gray (N 4) to dark greenish gray (10Y 4/1) mud and diamict. They account for $>95 \%$ of the cores recovered. Photographs of the most common facies are shown in Figure F6. Based on characteristic facies associations, two lithostratigraphic units were defined (Table T3).

\section{Facies description}

Nine lithofacies were identified and are outlined in Table T2. All of these are included within the group of facies observed at other Expedition 341 sites. Facies numbering is based on those documented for all sites, but only facies documented at Site U1421 are discussed here. These include massive mud with lonestones (F1a), massive mud without lonestones (F1b), interbedded mud and diamict (F4d), clast-poor diamict (F4e), clast-rich diamict (F4f), diatom ooze (F5a), mud with diatoms/biosilica (F5b), calcareous/ carbonate-bearing mud (F5c), and mud and diamict with volcanic ash (F7).

The massive mud with lonestones of Facies F1a is mostly very dark gray ( $\mathrm{N} 3$ ) to dark greenish gray (10Y 4/1) and has bed thicknesses that range from 149 to $992 \mathrm{~cm}$ (Table T2; Fig. F6C). Clast abundance within the mud ranges from dispersed to abundant. Bioturbation is mostly absent. However, one interval is heavily bioturbated and contains traces of ash. Lonestones consist mainly of siltstone, sandstone, and basalt (Figs. F7A-F7I). This facies can occasionally be well consolidated (e.g., Sections 341-U1421A$7 \mathrm{H}-5$ through $8 \mathrm{H}-3$ ), and lamination occurs rarely. Facies F1b is composed of dark greenish gray (10Y 4/1) to dark gray (N 4) mud, comprising 5 to $595 \mathrm{~cm}$ thick intervals (Table T2; Fig. F6A-F6B). Bioturbation is mostly absent but is slight in one interval. Diatoms are relatively abundant, and shell fragments, foraminifers, and black mottles occur occasionally. Rare laminations are observed.

Dark gray (N 4) clast-poor diamict interbedded with laminae and up to $4 \mathrm{~cm}$ thick beds of mud composes Facies F4d (Table T2). The diamict contains granule and pebble clasts of siltstone, sandstone, granitoids, and greenstone. Bioturbation is absent, and shells are rare. Facies F4e is very dark gray (N 3) clast-poor 
diamict, most often with a silty or muddy matrix (Table T2; Fig. F6F). Beds are massive, and thicknesses range from 13 to $465 \mathrm{~cm}$. Common clast sizes are granule and pebble, with clasts being subangular to subrounded. Dominant clast lithologies are sandstone, siltstone, basalt, argillite, granitoid, rhyolite, and metasandstone (Fig. F7A-F7I). Bioturbation is absent, but some shell fragments are present. Facies F4f is very dark gray ( $\mathrm{N} \mathrm{3}$ ) to dark gray (N 4) clastrich diamict, typically with a muddy or silty matrix, often containing sand (Table T2; Fig. F6G). Shell fragments occur rarely, and bioturbation is absent. Bed thicknesses range from 3 to $344 \mathrm{~cm}$. Common clast sizes and lithologies are similar to those described for Facies F4e.

Facies F5a is composed of dark greenish gray (10Y 4/1) diatom ooze. It includes 12 to $142 \mathrm{~cm}$ thick intervals that are either laminated without bioturbation or that are massive and slightly or heavily bioturbated (Table T2; Figs. F6D, F7J). Lonestones are absent, and shell fragments occur occasionally (Fig. F7K). Facies F5b consists of 19 to $595 \mathrm{~cm}$ thick dark greenish gray (10Y 4/1) mud with absent to abundant clasts. This facies is most often diatom bearing and contains occasional sponge spicules (Table T2; Fig. F6H). Bioturbation is mostly absent or limited. Shell fragments, black mottles, and foraminifers occur occasionally. Trace amounts of volcanic ash are rare. Facies F5c contains grayish green (10Y 4/2) diatom-rich mud with foraminifers (Table T2). This facies is found in 15 to $18 \mathrm{~cm}$ thick intervals. Bioturbation is slight, and black mottles are present. Facies F7 is defined as dark gray ( $\mathrm{N} 4$ ) diamict and dark greenish gray (10Y 4/1) diatom-bearing mud with traces of volcanic ash (Table T2). Bioturbation is heavy in the mud but absent in the diamict. The thickness of this facies varies from 46 to $67 \mathrm{~cm}$.

\section{Lithostratigraphic units}

Based on facies associations observed in Holes U1421A-U1421C, two lithostratigraphic units are defined (Table T3). The contact between lithostratigraphic units at Site U1421 is gradational, and the criteria used to define units are discussed below.

\section{Unit I}

Intervals: $341-\mathrm{U} 1421 \mathrm{~A}-1 \mathrm{H}-1,0 \mathrm{~cm}$, to $7 \mathrm{H}-5,20 \mathrm{~cm}$; $341-\mathrm{U} 1421 \mathrm{~B}-1 \mathrm{H}-1,0 \mathrm{~cm}$, to $1 \mathrm{H}-\mathrm{CC}, 18 \mathrm{~cm} ; 341-$ $\mathrm{U} 1421 \mathrm{C}-1 \mathrm{H}-1,0 \mathrm{~cm}$, to $6 \mathrm{H}-\mathrm{CC}, 36 \mathrm{~cm}$

Depths: Hole U1421A $=0-57 \mathrm{~m}$ core depth below seafloor (CSF-A); Hole U1421B = 0-6.23 m CSFA; Hole U1421C = 0-38.22 m CSF-A

Age: Middle Pleistocene to Holocene
Very dark gray (N 3) to dark greenish gray (10Y 4/1) mud, diatom-bearing mud, and diatom-rich mud extends from 0 to $57 \mathrm{~m} \mathrm{CSF-A} \mathrm{in} \mathrm{Hole} \mathrm{U1421A.} \mathrm{The}$ amount of lonestones varies from dispersed to abundant deeper than $6.4 \mathrm{~m} \mathrm{CSF-A.} \mathrm{One} \mathrm{interval} \mathrm{of} \mathrm{olive}$ (5Y 5/3) laminated mud was deposited above the bed containing the uppermost lonestones (Fig. F6B). All recovery in Holes U1421B and U1421C is in Unit I.

\section{Unit II \\ Interval: $341-\mathrm{U} 1421 \mathrm{~A}-7 \mathrm{H}-5,20 \mathrm{~cm}$, to $85 \mathrm{X}-1,95$ $\mathrm{cm}$ \\ Depth: Hole U1421A = 57-702.7 m CSF-A \\ Age: Middle Pleistocene to Holocene}

Dark gray (N 4) to very dark gray (N 3) clast-poor and clast-rich diamict, as well as mud with abundant clasts, characterize this unit. Diamict beds contain subrounded to subangular, granule- to pebble-sized clasts. The clasts have diverse lithologies, including siltstone, sandstone, argillite, quartz, greenstone, granitoid, and diorite. The Unit I/II boundary corresponds with an increase in gamma ray attenuation (GRA) bulk density from 1.9 to $2.2 \mathrm{~g} / \mathrm{cm}^{3}$, where it remains throughout the clast-rich intervals within Unit II (Fig. F8). Biosilica-rich or diatom-rich mud occurs in Cores 341-U1421A-22X, 41X, and 55X through 57X. Diatom ooze occurs in Cores 61X through $63 \mathrm{X}$ and $75 \mathrm{X}$. Dark greenish gray (10Y 4/1) finely laminated diatom ooze occurs in Section 341U1421A-63X-1.

\section{Clast lithologies}

\section{Petrography}

The main lithologies of the diamict clasts and lonestones contained in Site U1421 sediment (Fig. F7AF7I) are, in order of decreasing abundance, sandstone, siltstone, basalt, argillite, granitoid, and rhyolite. The granitoid group includes intermediate and felsic intrusive rocks. Metasandstone, gneiss, metasiltstone, mudstone, and greywacke represent minor lithologies. The distribution of lithologies, according to the main lithology types, metamorphic (M), igneous (I), and sedimentary (S) (Fig. F9), reveals the predominance of sedimentary lithologies over igneous and metamorphic ones. The average clast ratio for Site U1421 is $\mathrm{M}_{12} \mathrm{I}_{33} \mathrm{~S}_{55}$ (Fig. F9).

\section{Bulk mineralogy}

X-ray diffraction (XRD) analyses were performed on 29 powdered bulk samples from Hole U1421A to characterize the bulk mineralogy and identify compositional trends with age or depth in the cores. The resulting diffraction patterns are shown in Figure 
F10, and the relative mineral diffraction peak intensities, as defined in "Lithostratigraphy" in the "Methods" chapter (Jaeger et al., 2014), are listed in Table T4. In general, the mineralogy was uniform downhole, although there are some variations in relative peak intensities, which may indicate slight variations in mineral content. Figure F10A shows the scans for five representative samples. The primary minerals identified include quartz, plagioclase (feldspar), mica (muscovite/illite and biotite), and chlorite and/or kaolinite. Quartz and plagioclase are the dominant peaks, with quartz generally the larger, and chlorite and/or kaolinite are present in all samples. Figure F10B shows the comparative XRD patterns from $4^{\circ}$ to $24^{\circ} 2 \theta$, where the scans were run before and after the samples had undergone a glycolization treatment (see "Lithostratigraphy" in the "Methods" chapter [Jaeger et al., 2014]). The scans suggest the presence of expandable clay minerals from $~ 95 \mathrm{~m}$ CSF-A downhole, with the exception of the sample at $295 \mathrm{~m}$ CSF-A. Our preliminary findings are similar to the results of Molnia and Hein (1982), which analyzed samples collected on the continental shelf of the Gulf of Alaska.

\section{Lithostratigraphy and depositional interpretations}

The distribution of primary sedimentary lithologies at Site U1421 is summarized in Figure F11. Unit I is characterized by the presence of very dark gray $(\mathrm{N} 3)$ to dark greenish gray (10Y 4/1) mud with varying clast concentrations (dispersed, common, and abundant). Dark greenish gray (10Y 4/1) diatom-rich mud and diatom-bearing mud is dominant in the upper $8.3 \mathrm{~m}$ and exhibits millimeter-scale laminations over a $10 \mathrm{~cm}$ thick interval centered at $6.1 \mathrm{~m}$ CSF-A. Unit II mostly consists of clast-rich and clast-poor diamict, with minor amounts of diatom ooze and diatom-rich mud. Bioturbation is heavy (intensity index $=3$ ) in some but not all of these biosiliceous intervals; laminated diatom-rich mud and diatom ooze are observed between 441 and 442 m CSF-A and 494 and $500 \mathrm{~m}$ CSF-A, respectively. Core recovery averages $24 \%$ within Unit II, and low-recovery cores $(<10 \%)$ contain washed pebbles, drilled rock, and $<0.5 \mathrm{~cm}$ thick intervals of clast-rich diamict. The low recovery interval between 25 and $36 \mathrm{~m}$ CSF-A was partly recovered in Hole U1421C (see "Stratigraphic correlation") and largely consists of mud with abundant and common clasts, which is the same lithology observed on Hole U1421A. Sediment cores from Hole U1421C contain mud with common and abundant clasts.

\section{Unit I}

Lithostratigraphic Unit I consists mainly of diatombearing and diatom-rich mud with lonestones and silty mud with dispersed to abundant clasts. Lonestones occur deeper than $6.4 \mathrm{~m}$ CSF-A in Hole U1421A. We interpret most of the mud as having been deposited through suspension settling from turbid meltwater plumes from tidewater glaciers. The diatom-rich intervals might be related to one or several processes:

- Increased biological productivity due to optimized oceanographic conditions (e.g., reduced sea ice cover, surface layer overturning, and/or mixing by gyres; Addison et al., 2012);

- Enhanced macro (N, P) and/or micro (Fe) nutrient supply from land (through volcanic ash, dust, etc.) leading to increased biological productivity (Addison et al., 2012; Davies et al., 2011; Hamme et al., 2010);

- Increased biological productivity in the water column in the vicinity of sea ice margins (Sakshaug, 2004; Smith et al., 1987);

- Seawater silica saturation, leading to a higher diatom productivity and preservation (e.g., Brzezinski et al., 1998; Dugdale et al., 1995); and/or

- Decreased input of terrigenous sediment (i.e., less dilution).

Thin laminations (Fig. F6B) observed in the diatombearing mud shallower than $6.4 \mathrm{~m}$ CSF-A in Hole U1421A (and also in the upper $8 \mathrm{~m}$ CSF-A at Site U1419) may point to hypoxic benthic conditions associated with enhanced sea-surface productivity as previously documented by Addison et al. (2012).

The lonestones are interpreted to have been rafted by icebergs calved from tidewater glaciers (Davies et al., 2011; Powell and Molnia, 1989). The sources for clasts documented in Unit I are interpreted to be the onshore St. Elias and Chugach Mountains located along the southern coast of Alaska. Siltstone and sandstone clasts, the most common clast types (Fig. F9), may have been derived from the Kulthieth, Poul Creek, and Yakataga Formations. The large number of volcanic clasts, especially the basaltic clasts, may have derived from the basaltic strata in the Poul Creek Formation (Plafker, 1987). The less common metasedimentary clast lithologies were probably derived from the Mesozoic accretionary prism strata and the metamorphic core complex rocks exposed in the Chugach and St. Elias Mountains (Plafker et al., 1994; Gasser et al., 2011). Felsic igneous clasts may have been derived from the Sanak-Baranoff plutons 
found dispersed along the southern Alaska margin (Sisson et al., 2003).

\section{Unit II}

Clast-rich and clast-poor diamict (Facies F4e and F4f) are the major lithologies of Unit II, suggesting a glacigenic origin for these deposits. The sedimentary processes leading to the deposition of the diamict facies include ice rafting and downslope transport of glacigenic sediment deposited at or beyond the grounding line in the vicinity of the shelf break.

Overconsolidation measured with the vane shear in Sections 341-U1421A-7H-5 through 8H-3 (Fig. F12A) suggests either deposition by a glacigenic debris flow or downslope transport of a coherent block of subglacial sediment (e.g., Vorren et al., 1998). Other evidence of downslope transport includes erosive lower boundaries of diamict and soft-sediment deformation in intervals of laminated diatom ooze within diamict (e.g., Core 341-U1421A-62X; Fig. F6J).

The main source of the reworked sediment is most likely the Bering Trough, located upslope from Site U1421, which may have acted as a pathway for an ice stream draining parts of the Cordilleran Ice Sheet into the Gulf of Alaska and transporting large amounts of sediment to the shelf break. Muddy intervals with biogenic silica and low clast abundance are suggested to reflect reduced ice rafting and/or increased productivity.

\section{Paleontology and biostratigraphy}

Microfossil abundances are generally low in Hole U1421A (Fig. F13). Based on radiolarian and diatom biostratigraphy, the bottom of the hole (near $700 \mathrm{~m}$ CSF-A) is younger than $300 \mathrm{ka}$ and older than $30 \mathrm{ka}$. Benthic and planktonic foraminifers are better preserved than the siliceous microfossils and occur throughout the record. Changes in the composition of the benthic foraminiferal fauna suggest changes in the degree of sediment transport from the shelf. Transport from the shelf is also supported by the presence of the neritic and coastal diatoms and neritic radiolarians.

\section{Diatoms}

In order to define the sediment depositional age and paleoenvironmental conditions, core catcher samples and samples from selected split core sections from Hole U1421A were investigated (Table T5). Of the 112 samples analyzed in Hole U1421A, 76 are barren of diatoms.
Zone NPD 12 (present-[0.3 \pm 0.1$] \mathrm{Ma}$ ) is recognized in most of the diatom-bearing samples from Hole U1421A. Although the base of Zone NPD 12 is defined by the last occurrence (LO) of Proboscia curvirostris (Jousé) Jordan et Priddle (D120; $0.3 \pm 0.1 \mathrm{Ma}$ ), this taxon is not observed. However, one specimen of Proboscia barboi (Brun) Jordan et Priddle is found in Sample 341-U1421A-62X-CC (495.76 m CSF-A); the LO of $P$. barboi is at $\sim 0.3 \mathrm{Ma}$ (following Yanagisawa and Akiba, 1998). Neither P. curvirostris nor $P$. barboi are found deeper than Sample 62X-CC. Therefore, we consider all of the retrieved sediment to be within Zone NPD 12. For a detailed description of diatom zonal scheme and taxonomy, see the "Methods" chapter (Jaeger et al., 2014).

Diatom valve preservation varies strongly throughout the sediment column of Hole U1421A (Table T5) from poor to good (Fig. F13). The diversity of the diatom assemblage is low and exclusively consists of Pleistocene to Holocene species. In intervals where we observe higher diversity (e.g., $>15$ species in Samples 341-U1421A-1H-4W, $100 \mathrm{~cm}$, and 56X-2W, 46 $\mathrm{cm})$, the assemblages are mainly composed of coldwater species, including Neodenticula seminae (Simonsen et Kanaya) Akiba et Yanagisawa, Actinocyclus curvatulus Janisch in Schmidt, and Thalassiosira gravida Cleve (Sancetta, 1982; Medlin and Priddle, 1990). The presence of coastal and benthic diatoms, including resting spores of Chaetoceros, Thalassionema nitzschioides var. nitzschioides (Grunow) Mereschkowsky, and the tycoplanktonic diatom Paralia spp. (Hasle and Syvertsen, 1996) suggest that coastal waters influenced Site U1421 (Table T5; Figs. F13, F14).

\section{Radiolarians}

Radiolarian abundance and preservation are variable at Site U1421. Of 83 studied samples, 66 were barren of radiolarians. Where radiolarians occur (17 samples), their abundances range from rare to common and preservation is mostly poor to moderate (Fig. F13). Radiolarian species diversity is relatively low, and only 23 radiolarian species are encountered at this site (Table T6). The radiolarian faunas are consistent with those found in the Botryrostrobus acquilonaris Zone (0-0.5 Ma). The LO of Lychnocanoma sakaii Morley and Nigrini is encountered between Samples 341-U1421A-45X-CC (334.11 m CSF-A) and 46X-CC (343.59 m CSF-A), suggesting that sediments below $343.59 \mathrm{~m}$ CSF-A are older than $30 \mathrm{ka}$. The LO of Stylacontharium acquilonium Hays is not encountered at this site, suggesting that the bottom of the core is younger than $400 \mathrm{ka}$.

The radiolarian assemblages are dominated by coldand surface-water (deeper than $200 \mathrm{~m}$ water depth) species in the uppermost $200 \mathrm{~m}$ CSF-A, suggesting a 
neritic glacial environment according to Boltovskoy et al. (2010) (Fig. F14). Although cold-water neritic species continue to be abundant deeper than $\sim 200 \mathrm{~m}$ CSF-A, the relative abundance of deepwater radiolarians (deeper than $500 \mathrm{~m}$ water depth) increases as well. This increase may indicate progressive environmental change or is caused by sediment transport from shallow-water environments to this continental slope site. Based on radiolarian and diatom biostratigraphy, the bottom of the core (near $700 \mathrm{~m}$ CSF-A) is between 30 and $300 \mathrm{ka}$.

\section{Foraminifers}

Core catcher and split core section samples from Hole U1421A were examined for planktonic foraminifers from the $>150 \mu \mathrm{m}$ size fraction in 44 samples (Table T7) and for benthic foraminifers from the $>150 \mu \mathrm{m}$ size fraction in 46 samples (Table T8). Unlike at other sites, the $63-150 \mu \mathrm{m}$ size was not examined for benthic foraminifers because the siliciclastic component overwhelms the foraminiferal component in that size fraction. Nearly all samples contain lithic clasts $>700 \mu \mathrm{m}$, and the $63-700 \mu \mathrm{m}$ fraction is typically dominated by nonbiogenic material. Exceptions are Samples 341-U1421A-22X-CC (114.68 m CSF-A), 55X-CC (432.84 $\mathrm{m}$ CSF-A), and 56X-CC (442.59 m CSF-A), where biogenic components (planktonic and benthic foraminifers and radiolarians) dominate the sand-silt fraction.

\section{Planktonic foraminifers}

Planktonic foraminifers are present in 39 of the 44 samples examined from Hole U1421A. Group abundances of planktonic foraminifers are generally present, except for one sample where group abundance is dominant (Table T7; Fig. F13). Planktonic foraminiferal preservation is generally good, except for one sample where preservation is moderate.

The planktonic foraminiferal assemblages are dominated by polar-subpolar species including Neogloboquadrina pachyderma (sinistral), Globigerina bulloides, and Globigerina umbilicata (Table T7), suggesting a cold-water environment (Fig. F14). N. pachyderma (dextral) is also present at this site, but its presence is sporadic and this taxon is generally $<10 \%$ of the total fauna (ranked as few).

Planktonic foraminifers examined in Samples 341U1421A-75X-CC and 77X-CC contain specimens that resemble Neogloboquadrina inglei (LO $0.7 \pm 0.1$ $\mathrm{Ma})$. The morphological features of these specimens agree with the original description of $N$. inglei (Kucera and Kennett, 2000), except for the coiling direction. In the California margin, $N$. inglei is exclusively dextral, whereas all specimens found at Site
U1421 are sinistral. Moreover, the $N$. inglei datum event disagrees with the biostratigraphy provided by diatoms and radiolarians, if we assume the LO of sinistral form of $N$. inglei is the same as that of dextral form reported from the California margin (Kucera and Kennett, 2000). The validity of this bioevent needs to be tested by additional morphological investigation and further chronostratigraphic control.

\section{Benthic foraminifers}

Benthic foraminifers are present in 44 of the 46 samples examined. Abundances are generally low because of the dominance of siliciclastic material, but benthic foraminifers are dominant to abundant in six samples (Table T8). Preservation is generally poor to moderate; however, when benthic foraminiferal abundances are high, preservation is good to very good (Fig. F13).

Elphidium spp. is abundant to dominant in $~ 80 \%$ of the samples (Fig. F14; Table T8), suggesting that much of the sediment originated in littoral to inner neritic environments ( $<100 \mathrm{~m}$ water depth). Other samples are dominated by Cassidulina cushmani, Eubuliminella exilis, Epistominella pacifica, or Islandiella norcrossi, which is consistent with sediments from middle neritic to middle bathyal ( 100-1500 m) water depths in the Gulf of Alaska (Bergen and O'Neil, 1979). When these taxa dominate, Elphidium spp. is often rare to absent, preservation is generally better, and abundances are generally higher. Specimens of Elphidium spp. are also more frequently fragmented than those of other taxa, but further research is necessary to quantify differences in preservation among taxa. Changes in the foraminiferal faunas and their preservation may reflect changes in sediment transport from shallower waters to Site U1421, with samples dominated by poorly preserved Elphidium spp. reflecting intervals of higher sedimentary input from the shelf. Alternatively, changes in faunal composition could partially reflect changes in water depth at the site.

\section{Stratigraphic correlation}

The composite depth scale at Site U1421 was constructed from 0.0 to $695.72 \mathrm{~m}$ core composite depth below seafloor (CCSF-A). The splice consists of one complete and continuous interval from the mudline to $33.21 \mathrm{~m}$ core composite depth below seafloor (CCSF-D). The CCSF-A and CCSF-D depth scales are defined in "Stratigraphic correlation" in the "Methods" chapter (Jaeger et al., 2014).

The splice ranges from the top of Core 341-U1421C$1 \mathrm{H}$ (the mudline) to the base of Core 5H (Tables T9, 
T10). Because only three holes were cored at Site U1421 (and Hole U1421B consisted of a single disturbed core), the splice only includes cores from Holes U1421A and U1421C and contains two "appended" intervals that are not strictly continuous with adjacent intervals.

Weather was calm and ship heave was negligible while coring Site U1421, but the lonestone- and sand-rich lithologies proved challenging for core recovery and for interhole correlation. Coring was terminated when the APC system was damaged by hitting an impenetrable layer; Core 341-U1421C-6H was recovered by tripping the pipe. Intervals of core disturbance, incomplete recovery, and use of the half APC coring system all presented complications in the development of composite depths and a spliced record. In particular, we observed many instances of flow-in and other coring disturbance. We urge caution in using the splice from Site U1421.

Correlations between holes were accomplished using Integrated Ocean Drilling Program Correlator software (version 1.695), and all the splice tie points were checked with digital line-scan images using Corelyzer (version 2.0.2), linked to Correlator. During coring, real-time development of composite depths and guidance for coring operations relied on Special Task Multisensor Logger (STMSL) GRA bulk density and magnetic susceptibility data. The final composite depth scale (CCSF-A) and the splice scale (CCSF-D) are based primarily on the stratigraphic correlation of magnetic susceptibility and GRA density from the Whole-Round Multisensor Logger (WRMSL) (Figs. F15, F16), as well as whole-round natural gamma radiation (NGR) and reflectance spectroscopy color data from the Section Half Multisensor Logger (SHMSL). Of these variables, magnetic susceptibility offered the most reliable tool for correlation at Site U1421; the other variables served primarily as verification data and were generally much noisier. Anomalously low GRA density was used primarily as an indicator of core disturbance. Magnetic susceptibility from the loop sensors was checked with point-sensor data, although the presence of small lonestones in intervals of diamict made those data relatively noisy.

The CCSF-A and CCSF-D depth scales were constructed by assuming that the uppermost sediment (the "mudline") in Core 341-U1421C-1H represented the sediment/water interface. An approximate mudline was also recovered in Core 341-U1421A-1H, confirming the fidelity of the top of the recovered interval. Core 341-U1421C-1H serves as the "anchor" in the composite depth scale and is the only core with depths that are the same on the CCSF-A and CCSF-D scales. From this anchor we worked downhole, matching the variations in core logging data on a core-by-core basis using Correlator.

The splice includes two append points. The base of Section 341-U1421A-2H-7 was appended to the top of Section 341-U1421A-3H-1 at 15.9 m CCSF-A. Additionally, the base of Section 341-U1421C-3H-7 was appended to Section 341-U1421A-4H-1 at $27.44 \mathrm{~m}$ CCSF-A. The splice is not strictly continuous at append points. Some disturbed material exists in the splice in Sections 341-U1421A-3H-1 and 341U1421C-4H-1; nevertheless, we considered these intervals sufficiently continuous to warrant inclusion in the splice.

Within the splice, the CCSF-A depth scale is (by definition) identical to the CCSF-D depth scale. Note that CCSF-D rigorously applies only to the spliced interval. Intervals outside the splice, although available with CCSF-A composite depth assignments, should not be expected to correlate precisely with fine-scale details within the splice or with other holes because of normal variation in the relative spacing of features in the recovered intervals from different holes. Such apparent depth differences may reflect coring artifacts or fine-scale spatial variations in sediment accumulation and preservation at and below the seafloor.

Given the short length of the splice and difficulties during coring, we did not calculate an affine growth factor at Site U1421. We also did not calculate a compressed depth scale (CCSF-B, see "Stratigraphic correlation" in the "Methods" chapter (Jaeger et al., 2014).

\section{Initial age model}

Shipboard paleomagnetic and biostratigraphic age datums are insufficient for the construction of a detailed initial shipboard age model (see "Paleomagnetism" and "Paleontology and Biostratigraphy"). Based on radiolarian and diatom biostratigraphy, the bottom of the hole (near $700 \mathrm{~m} \mathrm{CSF-A)}$ is younger than $300 \mathrm{ka}$ and older than $30 \mathrm{ka}$. Paleomagnetic measurements were all representative of normal magnetic polarity. We can conclude that the entire sedimentary sequence recovered at Site U1421 is younger than $0.781 \mathrm{Ma}$ and likely less than $0.3 \mathrm{Ma}$.

\section{Geochemistry Interstitial water chemistry}

Interstitial water (IW) samples were taken in Hole U1421A. A total of 26 IW samples were taken, with a resolution of two samples per core in Cores 341$\mathrm{U} 1421 \mathrm{~A}-1 \mathrm{H}$ and $6 \mathrm{H}$, three samples per core in Cores $2 \mathrm{H}$ and $3 \mathrm{H}$, and one sample per core from Core $7 \mathrm{H}$ 
to the bottom of the hole. Because of limited core recovery, the sampling resolution was low and irregular deeper than Core 341-U1421A-13H. Whole rounds for IW analysis were $5 \mathrm{~cm}$ long in Cores 341U1421A-1H through $7 \mathrm{H}$ and $10 \mathrm{~cm}$ long in Core $8 \mathrm{H}$ and deeper cores. Samples from Hole U1421A were collected from APC cores (0-94.7 m CSF-A) and XCB cores (94.7-607.8 m CSF-A), and the results below refer to the combined APC and XCB sample record. The applied squeezing pressures ranged from 8,000 to $32,000 \mathrm{psi}$, and the volumes of IW extracted ranged between 10 and $40 \mathrm{~mL}$. Splits of the IW samples were taken and processed following methods outlined in "Geochemistry" in the "Methods" chapter (Jaeger et al., 2014) using shipboard analyses or were preserved for shore-based analysis of dissolved trace metals, oxygen/sulfur/calcium/strontium isotopes, dissolved inorganic carbon, and silica.

\section{Alkalinity, pH, chloride, and salinity}

Alkalinity increases from $9.2 \mathrm{mM}$ (3.0 m CSF-A) to a maximum of $18.5 \mathrm{mM}$ at $47.8 \mathrm{~m}$ CSF-A (Fig. F17A). Following a decrease to $11.6 \mathrm{mM}$ by $68.5 \mathrm{~m}$ CSF-A, alkalinity remains around $11.5 \mathrm{mM}$ to $114.1 \mathrm{~m} \mathrm{CSF}-$ A. An isolated alkalinity maximum of $33.7 \mathrm{mM}$ occurs at $440.7 \mathrm{~m}$ CSF-A, followed by another decrease to $6.2 \mathrm{mM}$ at $626.5 \mathrm{~m}$ CSF-A. The corresponding $\mathrm{pH}$ values at Site U1421 range between 7.4 and 7.8 in the uppermost $63 \mathrm{~m}$ CSF-A and between 7.6 and 7.8 at greater depths (Fig. F17B).

The chloride concentration profile at Site U1421 continuously decreases from $528.8 \mathrm{mM}$ (3.0 m CSFA) to $361.0 \mathrm{mM}$ (49.3 m CSF-A), followed by a slight increase to $392.8 \mathrm{mM}$ by $94.7 \mathrm{~m}$ CSF-A (Fig. F17J). Chloride concentrations remain between 380 and $415 \mathrm{mM}$ to $494.3 \mathrm{~m}$ CSF-A. Starting at $577.7 \mathrm{~m}$ CSFA, concentrations increase to $446 \mathrm{mM}$, reaching 467 $\mathrm{mM}$ by $626.5 \mathrm{~m}$ CSF-A.

The overall pattern of the chloride profile at Site U1421 is also reflected in salinity, with decreasing values from $31 \mathrm{mM}$ (3.0 m CSF-A) to $20 \mathrm{mM}(49.3 \mathrm{~m}$ CSF-A) followed by a slight increase to 22 by $94.7 \mathrm{~m}$ CSF-A. Salinity stays between 21 and 23 to $494.3 \mathrm{~m}$ CSF-A. At $577.7 \mathrm{~m}$ CSF-A, salinity values increase to 25 and reach 26 by 626.5 m CSF-A (Fig. F17I).

\section{Dissolved ammonium, phosphate, and silica}

Dissolved ammonium concentrations increase rapidly from $0.73 \mathrm{mM}$ at $3.0 \mathrm{~m}$ CSF-A to $1.82 \mathrm{mM}$ at $47.8 \mathrm{~m}$ CSF-A (Fig. F17D). Following a decrease to $1.48 \mathrm{mM}$ by $88.0 \mathrm{~m}$ CSF-A, ammonium concentrations continue to rise more gradually downcore, reaching a maximum of $5.06 \mathrm{mM}$ (485.7 m CSF-A).
At greater depths, ammonium concentrations decrease to $4.05 \mathrm{mM}$ (626.5 m CSF-A).

Phosphate concentrations at Site U1421 decrease rapidly from $29.1 \mu \mathrm{M}$ at $3.0 \mathrm{~m}$ CSF-A to $1.9 \mu \mathrm{M}$ at $94.6 \mathrm{~m}$ CSF-A (Fig. F18J). At greater depths, phosphate increases to $21.6 \mu \mathrm{M}$ at $295.5 \mathrm{~m}$ CSF-A. An isolated phosphate maximum of $42.5 \mu \mathrm{M}$ occurs at $440.6 \mathrm{~m}$ CSF-A, followed by another decrease to 1.1 $\mu \mathrm{M}$ by $607.8 \mathrm{~m}$ CSF-A.

Silica concentrations range from 394 to $861 \mu \mathrm{M}$ (Fig. $\mathrm{F} 17 \mathrm{H})$. Values are highly variable in the uppermost $100 \mathrm{~m}$ CSF-A and deeper than $500 \mathrm{~m}$ CSF-A. Between 431.9 and $494.3 \mathrm{~m}$ CSF-A, silica values are consistently around $800 \mu \mathrm{M}$.

\section{Dissolved sulfate, calcium, magnesium, potassium, sodium, and bromide}

Sulfate concentrations at Site U1421 linearly decrease with depth between 3.0 and $19.3 \mathrm{~m}$ CSF-A (from 20.7 to $3.0 \mathrm{mM}$ ), with the latter depth defining the depth of total sulfate depletion (Fig. F17C). At greater depths, sulfate concentrations range between 2.9 and $3.7 \mathrm{mM}$.

Calcium concentrations decrease continuously with depth between 3.0 and $47.8 \mathrm{~m}$ CSF-A (from 8.5 to 3.9 $\mathrm{mM}$ ) (Fig. F18A), followed by a minor increase to 5.5 $\mathrm{mM}$ at $81.7 \mathrm{~m}$ CSF-A. Starting at $431.8 \mathrm{~m} \mathrm{CSF-A,} \mathrm{cal-}$ cium concentrations increase gradually downcore (3.9 to $5.4 \mathrm{mM}$ ), with a steeper gradient between 577.6 and $626.4 \mathrm{~m}$ CSF-A (from 6.4 to $11.4 \mathrm{mM}$ ).

Magnesium concentrations decrease strongly from 47.7 to $24.7 \mathrm{mM}$ between 3.0 and $47.8 \mathrm{~m}$ CSF-A (Fig. F18C). A minor increase in magnesium concentrations to $32.0 \mathrm{mM}$ occurs at $81.7 \mathrm{~m} \mathrm{CSF}-\mathrm{A}$. At greater depths, magnesium varies between 26.0 and 34.0 $\mathrm{mM}$, returning to higher concentrations (36.6-42.3 $\mathrm{mM}$ ) deeper than 577.7 m CSF-A.

Potassium concentrations strongly decrease downcore from 10.1 to $5.8 \mathrm{mM}(3.0-22.3 \mathrm{~m} \mathrm{CSF}-\mathrm{A})$ and then decrease more gradually to $4.6 \mathrm{mM}$ at $114.1 \mathrm{~m}$ CSF-A (Fig. F18B). At greater depths, potassium concentrations remain low, between 4.2 and $5.7 \mathrm{mM}$.

Sodium concentrations continuously decrease from $445.7 \mathrm{mM}$ (3.0 m CSF-A) to $292.2 \mathrm{mM}$ (49.3 m CSFA) (Fig. F17K). Sodium concentrations increase slightly to $411.0 \mathrm{mM}$ at $94.7 \mathrm{~m} \mathrm{CSF-A}$ and then fluctuate between 284.1 and $318.3 \mathrm{mM}$ down to $494.3 \mathrm{~m}$ CSF-A. Deeper than 577.7 m CSF-A, sodium concentrations increase to $320.8 \mathrm{mM}$, reaching $337.8 \mathrm{mM}$ by $626.5 \mathrm{~m}$ CSF-A.

Bromide concentrations continuously decrease from $0.81 \mathrm{mM}$ (3.0 m CSF-A) to $0.60 \mathrm{mM}$ (49.3 m CSF-A), 
followed by a slight increase to $0.67 \mathrm{mM}$ at $94.7 \mathrm{~m}$ CSF-A (Fig. F17E). At greater depths, bromide concentrations range between 0.62 and $0.85 \mathrm{mM}$ down to $494.3 \mathrm{~m}$ CSF-A. Between 577.7 and $626.5 \mathrm{~m}$ CSF$\mathrm{A}$, values range between 0.84 and $0.90 \mathrm{mM}$.

\section{Dissolved manganese, iron, barium, strontium, boron, and lithium}

Manganese concentrations at Site U1421 generally vary between 2.5 and $4.9 \mu \mathrm{M}$ without any distinct downcore pattern apart from an increase to $7.5 \mu \mathrm{M}$ at the bottom of the hole (Fig. F18I).

Dissolved iron concentrations at Site U1421 vary between quantification limit and $12.7 \mu \mathrm{M}$, with the highest values mostly limited to the uppermost 120 m CSF-A (Fig. F18H). Also between 431.9 and 577.7 m CSF-A, iron concentrations reach $2.2 \mu \mathrm{M}$.

Barium concentrations are below detection limit at Site U1421 down to $15.7 \mathrm{~m}$ CSF-A and then gradually increase to values between 7.5 and $16.4 \mu \mathrm{M}$ down to $114.1 \mathrm{~m}$ CSF-A (Fig. F18F). Deeper than $431.9 \mathrm{~m}$ CSF-A, barium shows an overall increasing trend to reach maximum concentrations of $50.4 \mu \mathrm{M}$ at the bottom of the hole.

Strontium concentrations increase from 84 to $98 \mu \mathrm{M}$ between 3.0 and $19.3 \mathrm{~m}$ CSF-A and then display a local minimum of $87 \mu \mathrm{M}$ at $47.8 \mathrm{~m}$ CSF-A (Fig. F18G). At greater depths, an intermittent increase in strontium concentrations to $121 \mu \mathrm{M}$ occurs at $88.1 \mathrm{~m}$ CSF-A. Deeper than 431.9 m CSF-A, strontium concentrations increase downcore from 70 to $189 \mu \mathrm{M}$ by 626.5 m CSF-A.

Boron concentrations decrease from $\sim 450 \mu \mathrm{M}$ to $<250 \mu \mathrm{M}$ between the top of the hole and $114.1 \mathrm{~m}$ CSF-A. At greater depths, boron varies between 100 and $500 \mu \mathrm{M}$ without any distinct depth trend.

Lithium concentrations at Site U1421 show a steep decrease in two steps, first from 20.8 to $15.4 \mu \mathrm{M}$ by $22.3 \mathrm{~m}$ CSF-A and then from 16.2 to $9.6 \mu \mathrm{M}$ by 68.5 m CSF-A (Fig. F17D). At greater depths, lithium concentrations are highly variable, ranging between 9.5 and $22.8 \mu \mathrm{M}$.

\section{Volatile hydrocarbons}

Headspace gas samples were collected at a resolution of one per core in Hole U1421A only, partly from core catchers (Cores 341-U1421A-2H through 76X). Methane is the dominant hydrocarbon gas detected. Methane is in very low concentrations $(<5 \mathrm{ppmv})$ in Cores 341-U1421A-2H and 3H but increases starting in Core $4 \mathrm{H}$ and in general ranges between 1,000 and 34,000 ppmv throughout Hole U1421A (Fig. F17F). Three intervals of high methane concentrations occur (>10,000 ppmv): at 47.8-63.3, 256.1-304.6, and
$501.3 \mathrm{~m}$ CSF-A. Ethane is only intermittently present, and concentrations remain very low throughout Hole U1421A ( $<6$ ppmv; Fig. F17G). The $\mathrm{C}_{1} / \mathrm{C}_{2}$ ratio is correspondingly high (generally $1,000-36,000$ ), indicating no threat to drilling operations.

\section{Bulk sediment geochemistry}

Discrete core samples were analyzed from Site U1421 for total carbon, total nitrogen (TN), and total inorganic carbon. From these analyses, total organic carbon (TOC) and calcium carbonate $\left(\mathrm{CaCO}_{3}\right)$ were calculated as described in "Geochemistry" in the "Methods" chapter (Jaeger et al., 2014). In total, 44 samples were analyzed from Hole U1421A (Cores 341-U1421-1H through 63X). Discrete samples were selected in collaboration with the Lithostratigraphy group to ensure that the primary lithologies were analyzed.

TOC contents mostly range between 0.4 and 1.0 wt $\%$ with no clear downcore trend (Fig. F19A). One sample with a TOC content of $1.26 \mathrm{wt} \%(171.2 \mathrm{~m}$ CSF-A) was sampled within a gray diamict (see "Lithostratigraphy").

TN contents are $<0.1$ wt $\%$ (Fig. F19B). The highest TN contents primarily occur deeper than $431.5 \mathrm{~m}$ CSF-A.

Organic carbon to $\mathrm{TN}(\mathrm{C} / \mathrm{N})$ ratios range between 9 and 42 (with one sample of 58) (Fig. F19C), consistent with a contribution from both marine and terrigenous organic matter (Hedges et al., 1986; Walinsky et al., 2009). The lowest $\mathrm{C} / \mathrm{N}$ values occur deeper than $431.5 \mathrm{~m}$ CSF-A and correspond to the presence of dark greenish gray bioturbated and laminated mud lithologies (see "Lithostratigraphy"). Low C/N ratios at 113.8 and $295.2 \mathrm{~m}$ CSF-A also occur within gray diamict and dark greenish gray bioturbated mud lithologies. In contrast, high $\mathrm{C} / \mathrm{N}$ ratios seem to dominate the upper and middle part of the record, where the lithology is dominated by mud with lonestones and diamicts. Determination of the contribution of inorganic $\mathrm{N}$ is required to fully assess the relative contributions of marine and terrigenous input to the organic matter at Site U1421.

$\mathrm{CaCO}_{3}$ values range mostly between 1.5 and $3.0 \mathrm{wt} \%$ (Fig. F19D). The highest $\mathrm{CaCO}_{3}$ contents of up to 4.8 wt $\%$ are recorded in dark greenish gray mud (295.2 m CSF-A; Core 341-U1421A-41X) and dark gray mud (500.7 m CSF-A; Core 63X), but not every mud-rich lithology appears to be equally enriched in carbonate (see "Lithostratigraphy").

\section{Interpretation}

The IW and sediment composition at Site U1421 indicate moderate to high rates of organic matter re- 
mineralization. Although TOC contents at Site U1421 are low (mostly $<1 \mathrm{wt} \%$ ), the tentatively high sedimentation rates mean that respective accumulation rates are also high (see "Stratigraphic correlation"). The potentially higher organic matter accumulation rates seem to drive relatively intense diagenetic processes occurring at Site U1421, discussed below. The $\mathrm{C} / \mathrm{N}$ ratios throughout the Site U1421 record show significant variability, and clear relationships exist between low $\mathrm{C} / \mathrm{N}$ ratios and dark greenish gray mud-rich lithologies and between high $\mathrm{C} / \mathrm{N}$ ratios and grayish lonestone-rich mud/diamict lithologies, implying changes in the dominant sources of organic material through time. The $\mathrm{CaCO}_{3}$ contents are also generally low but indicate a significant contribution of biogenic carbonate to the sediment composition, which is in agreement with abundances and preservation of foraminifers at Site U1421, especially within mud-rich lithologies (see "Paleontology and biostratigraphy").

At Site U1421, both ammonium and alkalinity show relatively moderate concentrations in the upper 100 $\mathrm{m}$ CSF-A, indicating that diagenesis is likely driven by the substantial input of refractory organic matter (supported by $\mathrm{C} / \mathrm{N}$ ratios of 20 to 40 ), possibly reflecting the location of Site U1421 on a glacial trough mouth fan. In this upper part of the sediment record, organic matter degradation seems to proceed mostly via dissimilatory iron reduction and sulfate reduction, whereas manganese reduction is negligible in the studied depth interval. In the deeper part of the record (deeper than $400 \mathrm{~m}$ CSF-A), ammonium concentrations more than double, whereas alkalinity stays at moderate levels (apart from an alkalinity maximum at $440.7 \mathrm{~m}$ CSF-A within a mud-rich lithology; see "Lithostratigraphy"). The high ammonium concentrations deeper than $400 \mathrm{~m}$ CSF-A coincide with a clear decrease in $\mathrm{C} / \mathrm{N}$ ratios, suggesting a sediment interval with more reactive marine organic matter that is being remineralized.

Methane concentrations within this high-ammonium interval are moderate, and sulfate is close to its detection limit, so neither sulfate reduction nor methanogenesis appear to be the dominant organic matter degradation pathways deeper than $400 \mathrm{~m}$ CSF-A. However, dissolved iron concentrations are slightly but consistently elevated at this depth in the sediment, suggesting that dissimilatory iron reduction might be occurring. This process requires the preservation of iron (oxyhydr)oxides in these deep, anoxic sediments, which is a distinct possibility given the tentatively very high sediment accumulation rates at Site U1421 (see "Stratigraphic correlation"). Both organic matter degradation and the dissolution of iron (oxyhydr)oxides are most likely responsible for the release of phosphate to the pore solution, not only in the deeper part of Hole U1421A, but also in the uppermost $60 \mathrm{~m}$ CSF-A.

At Site U1421, almost complete sulfate depletion is

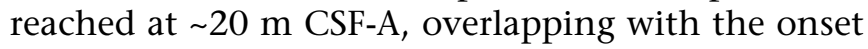
of methane production, which indicates the anaerobic oxidation of methane coupled to sulfate reduction in a sulfate-methane transition zone (SMTZ). Calcium, magnesium, strontium, and lithium exhibit sinks within the SMTZ, possibly related to the formation of authigenic carbonates. Deeper than the SMTZ, the release of barium to the IW indicates dissolution of barite under sulfate-depleted conditions in the methanogenic zone. Contamination by seawater sulfate during drilling is unlikely, as the elevated sulfate values occur in both $\mathrm{APC}$ and $\mathrm{XCB}$ cores.

At Site U1421, chloride concentration, salinity, and sodium decrease substantially with depth. Dehydration of clay minerals should not occur at such shallow burial depths (Saffer and McKiernan, 2009). Reduced IW salinities have been frequently observed in sediments overlying methane hydrate reservoirs (e.g., Hesse, 2003; Torres et al., 2004) because of the low-salinity water released upon hydrate dissociation. However, no bottom-simulating reflector was observed at Site U1421 (see "Background and objectives"), and we observed only moderate (mostly $<20,000$ ppmv) methane headspace concentrations, so gas hydrate dissociation is an unlikely explanation for the IW freshening. Studies on marine IW salinities adjacent to modern ice sheets of Greenland (Ocean Drilling Program Leg 152; Gieskes et al., 1998; DeFoor et al., 2011) and Antarctica (Lu et al., 2010) have revealed that substantial IW freshening might be related to glacial meltwater discharge events. To estimate the impact of freshwater dilution on the IW profiles, concentrations of all chemical parameters are normalized to downcore chloride concentrations. Selected normalized profiles are shown in Figure F20. Although the shape of the bromide profile is significantly affected by dilution from fresher waters, all other IW profiles maintain their original downcore trends after normalization.

\section{Physical properties}

Physical properties measurements were taken at Site U1421 to provide basic information for characterizing the drilled section using whole-round cores, split cores, and discrete samples. After cores were divided into sections, all whole-round core sections longer than $\sim 30 \mathrm{~cm}$ were measured through the GRA bulk densitometer and magnetic susceptibility loop on the STMSL at $5.0 \mathrm{~cm}$ intervals with $2 \mathrm{~s}$ measure- 
ments. GRA bulk density and magnetic susceptibility were measured with the WRMSL at $2.5 \mathrm{~cm}$ intervals with $5 \mathrm{~s}$ measurements. Compressional wave $(P$ wave) velocity was also measured on the WRMSL track for all APC cores at this site. After WRMSL scanning, the whole-round sections were logged for NGR at $10 \mathrm{~cm}$ intervals. Color spectrometry, color reflectance, and magnetic susceptibility were measured on the split cores using the SHMSL at $2.5 \mathrm{~cm}$ resolution. Discrete measurements on the working half sections of Hole U1421A include $P$-wave and shear strength using the Section Half Measurement Gantry. Moisture and density (MAD) were also measured on 10 $\mathrm{cm}^{3}$ plugs collected from the working halves from Hole U1421A. No discrete measurements were performed on samples from Holes U1421B and U1421C. Summaries of all the physical properties measured from Holes U1421A and U1421C are provided in Figures F12 and F21, respectively.

\section{Gamma ray attenuation bulk density}

Variations in GRA bulk density in the recovered sections of Site U1421 likely reflect changes in mineralogy/lithology, consolidation, and porosity, which are overprinted by variable core recovery. Whole-round GRA bulk density averages $\sim 2.0 \mathrm{~g} / \mathrm{cm}^{3}$ at the site, with the lowest values occurring in the uppermost 6 $\mathrm{m}$ and large variability downcore (Figs. F12, F21). APC cores from the uppermost portion of the site were largely full to the width of the liner and hence are likely to produce approximately calibrated density. However, as in the other sites, in the reduced-diameter XCB core sections of Hole U1421A the absolute WRMSL bulk density values reflect a minimum limit.

\section{Magnetic susceptibility}

We evaluate the consistency between the WRMSL loop magnetic susceptibility meter and the SHMSL point-source magnetic susceptibility meter in the APC splice portion of Site U1421, where full core liners should limit the effect of sediment volume on the loop sensors. Both data sets were smoothed using a Gaussian filter of $10 \mathrm{~cm}( \pm 3 \sigma)$ and interpolated to 2.5 $\mathrm{cm}$ resolution to accommodate for the differing response functions of the instruments (see "Physical properties" in the "Methods" chapter (Jaeger et al., 2014), prior to comparison. We found an offset in the relative magnitude of the measurements, with loop magnetic susceptibility being an average of $\sim 1.45 \times$ greater than that of the point-source data from the Site U1421 composite splice (Fig. F22). In Hole U1421A XCB cores, the reduced core diameter is such that the relationship between loop magnetic susceptibility and point-source magnetic susceptibil- ity is likely to be driven by the volume of sediment in the WRMSL measurement window and cannot be expected to meaningfully reflect instrument reproducibility. As in the case of GRA bulk density, raw WRMSL magnetic susceptibility values should be regarded as a lower limit of sedimentary volumetric magnetic susceptibility.

We normalized loop magnetic susceptibility for changes in sediment recovery and compaction by dividing the volumetric mass susceptibility by the GRA bulk density after smoothing both data sets using a Gaussian filter of $10 \mathrm{~cm}( \pm 3 \sigma)$ to correct for the differing response functions of the instruments. This generates a mass magnetic susceptibility $(\chi)$ with units of cubic centimeters per gram (Fig. F23). Unlike at the other sites, this normalization appeared to increase the variance of the magnetic susceptibility data; however, this effect was attributed to a single event of up to $3000 \mathrm{IU}$ in the uncorrected WRMSL data spanning $5 \mathrm{~cm}$ between 637.175 and $637.225 \mathrm{~m}$ CCSF-A, which was magnified in the volume-normalized data. If this event is excluded from the calculation of variance, the reduction in the normalized data set is $\sim 10 \%$ relative to the uncorrected magnetic susceptibility data, similar to the effect of normalization on magnetic susceptibility variance at the other expedition sites. Mass magnetic susceptibility averages $\sim 65.5 \mathrm{~cm}^{3} / \mathrm{g}$ downhole at the site (Fig. F23). The record is characterized by a low-amplitude oscillation of $\sim 100 \mathrm{~m}$ in depth with superimposed periods of high variability. The lowest magnetic susceptibility of the recovered record is in the uppermost portion of the core, with an abrupt transition to higher values at $\sim 6 \mathrm{~m}$ CCSF-A. Variance is highest in the deepest $300 \mathrm{~m}$ of the cores and may reflect the presence of abundant ice-rafted debris clasts.

\section{Compressional wave velocity}

$P$-wave velocity was measured on the WRMSL $P$ wave logger (PWL) on all APC cores from Holes U1421A and U1421B. We halted PWL measurements in Hole U1421A when we switched to XCB coring with Core 341-U1421A-19H ( 95 m CSF-A). PWL values range from $\sim 1500 \mathrm{~m} / \mathrm{s}$ at the seafloor to $\sim 2000$ $\mathrm{m} / \mathrm{s}$ at $\sim 95 \mathrm{~m}$ CSF-A, generally increasing downhole. However, this trend is not strong, and there is increasing scatter deeper than $\sim 60$ m CSF-A (Fig. F12). PWL values show velocity peaks at $\sim 15$ and $\sim 65 \mathrm{~m}$ CSF-A, each associated with intervals of high density. $P$-wave measurements using the $P$-wave caliper (PWC) tool were taken at Site U1421 when core recovery allowed. Because of poor core recovery coinciding with the switch to XCB coring, few PWC measurements were taken deeper than $\sim 95$ m CSF-A. 
Much of the recovered material consists of clast-rich or clast-poor diamict (see "Lithostratigraphy"), the nature of which produces uneven contact with the $P$-wave calipers, so velocity measurements could not be obtained with regularity. PWC values were automatically picked where possible and manually picked when the automatic picker encountered errors when the calipers did not have sufficient contact with the sample because of abundant clasts, soft sediment, or bad coupling with the liner. PWC values show no significant overall trend with depth and vary widely, sometimes within the same section, likely because of the varying amounts and lithology of clasts. Though values generally range from $\sim 1500$ to $\sim 2000 \mathrm{~m} / \mathrm{s}$, occasional measurements of velocities $>2200 \mathrm{~m} / \mathrm{s}$ were also observed (Fig. F12). All discrete measurements at this site were taken within the dominant matrix lithology of the recovered interval.

Comparison of PWL and PWC measurements in the APC interval of Hole U1421A reveals that the PWC measurements are generally lower than the PWL values. A scatter plot shows the mismatch between the values, with a slope of $\sim 0.41$ (Fig. F24). Postcruise analysis is required to investigate the velocity discrepancy. Comparison of the PWC and PWL velocity values with the sonic log and vertical seismic profile (VSP) (see "Downhole logging") should be undertaken before using the data in any interpretations or analysis.

\section{Natural gamma radiation}

NGR was measured at $10 \mathrm{~cm}$ intervals on all wholeround core sections that exceeded $50 \mathrm{~cm}$ in length. NGR measurements show cyclic downcore fluctuations between 14 and 41 counts per second (cps) with a mean and standard deviation of 32 and 5, respectively. Downhole variations in raw NGR values are influenced by changes in porosity and core recovery volume and, consequently, parallel changes in GRA bulk density.

As with WRMSL magnetic susceptibility, we calculate an equivalent activity of the sediment by normalizing to the WRMSL GRA bulk density after smoothing the data sets with a Gaussian filter of $50 \mathrm{~cm}( \pm 3 \sigma)$ to accommodate for the varying response functions of the instruments. This normalization by GRA bulk density reduces downcore variance in NGR by $\sim 35 \%$. As NGR can only be collected on sections longer than $50 \mathrm{~cm}$, low recovery limits our interpretation of the portion of the NGR record deeper than $\sim 100 \mathrm{~m}$ CCSF-A (Fig. F25).

\section{Moisture and density}

Bulk density values in Hole U1421A were calculated from mass and volume measurements on discrete samples taken from the working halves of split cores (see "Physical properties" in the "Methods" chapter [Jaeger et al., 2014]). Depending on core recovery, quality, and lithology, one to three samples were taken per core. A total of 88 samples were analyzed for MAD.

Discrete bulk densities fit well with GRA bulk densities between $\sim 0$ and 100 m CSF-A (Fig. F8). Between $\sim 0$ and $25 \mathrm{~m}$ CSF-A, density increases from $\sim 1.7$ to 2.1-2.2 $\mathrm{g} / \mathrm{cm}^{3}$, approximately following an exponential curve. The interval between $\sim 26$ and $45 \mathrm{~m}$ CSF-A was not recovered. Deeper than $\sim 45 \mathrm{~m}$ CSF-A, density values generally range from $\sim 2.1$ to $2.4 \mathrm{~g} / \mathrm{cm}^{3}$, except for two lower density samples taken from muddier sediments (See "Lithostratigraphy"). In the intervals between 290 and 310 m CSF-A and between $\sim 450$ and $500 \mathrm{~m}$ CSF-A, densities display a wide range from $\sim 1.8$ to $2.6 \mathrm{~g} / \mathrm{cm}^{3}$ and show no discernible downhole trend. Generally, intervals of mud and diatom ooze have lower densities than intervals of diamict. Clast-rich diamict displays increased scatter relative to clast-poor diamict (Fig. F8). Bulk grain densities display considerable scatter, ranging from 2.7 to $3.1 \mathrm{~g} / \mathrm{cm}^{3}$ (Fig. F26).

Porosity measured on discrete samples displays large ranges of $\sim 24 \%-26 \%$ to $\sim 54 \%-56 \%$ from $\sim 280$ to 650 $\mathrm{m}$ CSF-A. These ranges do not appear to correspond with lithostratigraphic trends or patterns (Fig. F26).

\section{Shear strength}

Shear strength measurements were performed on working section halves from Hole U1421A using the automated vane shear testing system (see "Physical properties" in the "Methods" chapter [Jaeger et al., 2014]). Efforts were taken to avoid the locations of obvious drilling disturbance or cracks in the halfcore sample. Measurements were taken as close as possible to the positions of the MAD samples and PWC measurements. We obtained shear strength measurements on all APC cores (to 95 m CSF-A) and some $\mathrm{XCB}$ cores to $\sim 490 \mathrm{~m}$ CSF-A. Shear strength measurements were halted when the recovered material was hardened enough to crack upon penetration of the automated vane. Shear strength measurements indicate that sediments within the shallowest $\sim 25 \mathrm{~m}$ CSF-A are soft $(\sim 5-20 \mathrm{kPa})$. At $\sim 45$ $\mathrm{m}$ CSF-A, shear strength values show increasing scatter and do not display a strong trend with increasing depth. We observe two intervals of high shear strength $(>60 \mathrm{kPa})$ at $\sim 47$ and $\sim 60 \mathrm{~m} \mathrm{CSF-A} \mathrm{that} \mathrm{co-}$ incide with increased density and NGR (Fig. F12). All 
samples reflect the dominant lithology of the recovered sediment.

\section{Heat flow}

Temperature measurements were conducted using the APCT-3 during APC coring in Hole U1421C. Although four measurements were planned, only two were actually acquired because of operational difficulties caused by large lonestones. Two temperature measurements were taken in total (Fig. F27A), and a geothermal gradient was obtained from these two (Cores 341-U1421B-4H and 6H) within the depth interval of 29.0-38.2 m CSF-A. We display the best-fit trendline to determine temperature gradient (Fig. F27B):

$$
T(z)=0.0858 z+0.218,
$$

where $T(z)$ is in situ temperature at depth $z$ (m CSFA). The estimated geothermal gradient is $20.6^{\circ} \mathrm{C} / \mathrm{km}$.

\section{Paleomagnetism}

The natural remanent magnetization (NRM) of Site U1421 archive-half cores was measured before and after alternating field (AF) demagnetization. Peak AFs were generally restricted to a maximum of 10 or 20 $\mathrm{mT}$ for most sections recovered using the APC system with standard half-length and nonmagnetic full-length core barrels (see "Operations") and the XCB system (Table T11). Peak AFs of $30 \mathrm{mT}$ were used on Section 341-U1421A-62X-1A. A two-step measurement sequence with peak AFs of $10 \mathrm{mT}$, a three-step measurement sequence with peak AFs of 10 and $20 \mathrm{mT}$, and a five-step measurement sequence with peak AFs of $5,10,15$, and $20 \mathrm{mT}$ were all employed. In addition to the typical measurement interval of $2.5 \mathrm{~cm}$, a $1 \mathrm{~cm}$ interval was used when the recovery of suitable material for polarity determinations within a section was limited. The number of demagnetization steps, the peak field used, and the resolution of measurements reflected the demagnetization characteristics of the sediment, the severity of the drill string magnetic overprint, the desire to use low peak fields to preserve the magnetization for future shore-based studies, and the quality of the section recovered. Sections completely disturbed by drilling, as noted by the Lithostratigraphy and/or Paleomagnetism groups, were not measured. Lonestones were carefully removed prior to section measurement without disturbing the sediment. Data associated with intervals affected by obvious drilling deformation or large clasts were culled during data processing.
NRM intensities at Site U1421 were relatively strong before AF demagnetization, ranging from $10^{-1} \mathrm{~A} / \mathrm{m}$ in the APC-recovered intervals to $10^{-2} \mathrm{~A} / \mathrm{m}$ in the XCB-recovered intervals (Fig. F28). Whether this results from differences in material recovered or magnetic properties of the core type is not initially obvious. In the APC-recovered sections, the steel core barrels resulted in slightly higher intensities than in the nonmagnetic barrels prior to demagnetization. After AF demagnetization at peak fields of 10 or 20 $\mathrm{mT}$, intensities are generally in the $10^{-3}$ to $10^{-2} \mathrm{~A} / \mathrm{m}$ range and consistent throughout the recovered interval. Intensities from the APC-recovered intervals compared on their CSF-A depth scales are consistent between holes, varying at both the meter and decameter scales (Fig. F29).

Steep, positive inclinations observed in the APC section prior to demagnetization, likely due to the drill string magnetic overprint, were generally removed by peak AF demagnetization of $10 \mathrm{mT}$ (Fig. F29). After AF demagnetization, inclinations average around values expected (approximately $\pm 73.5^{\circ}$ ) for a geocentric axial dipole (GAD) at the site latitude for much of the recovered interval, although values significantly steeper or shallower than GAD predictions are not uncommon (Fig. F28). These steeper or shallower values are not an unexpected observation considering the clast-rich facies drilled. Almost exclusively positive inclinations are consistent with normal polarity throughout the recovered sequence, and it is therefore considered to be entirely within the Brunhes Chronozone (0-0.781 Ma; Cande et al., 1995; Hilgen et al., 2012), which is consistent with biostratigraphic evidence (see "Paleontology and biostratigraphy").

\section{Downhole logging Logging operations}

Logging operations for Site U1421 began after completion of APC/XCB operations in Hole U1421A, drilled to a total depth of $702.7 \mathrm{~m} \mathrm{DSF}$ at $1910 \mathrm{~h}$ on 26 July (Fig. F30). In preparation for logging, a $75 \mathrm{bbl}$ mud sweep was circulated to clean the hole. A godevil was then pumped down the hole, and the hole was displaced with $50 \mathrm{bbl}$ of high-viscosity mud, followed by $328 \mathrm{bbl}$ of barite-weighted mud (11.8 ppg). The pipe was raised to $96.6 \mathrm{~m}$ DSF for logging.

Two tool strings were deployed in Hole U1421A on the basis of potentially unstable borehole conditions and limited time at the end of the expedition: the Sonic-induction tool string and the VSI tool string. The Sonic-induction tool string, also deployed in Hole U1420A, was composed of the Enhanced Digi- 
tal Telemetry Cartridge, Hostile Environment LithoDensity Sonde (HLDS) without neutron source, Dipole Shear Sonic Imager (DSI), and Phasor Dual Induction-Spherically Focused Resistivity Tool, respectively measuring total gamma ray, borehole diameter, sonic velocity, and resistivity. The second tool string was the VSI tool string, run without the Hostile Environment Natural Gamma Ray Sonde because of concerns about borehole instability.

The Sonic-induction tool string was rigged up at $0130 \mathrm{~h}$ on 27 July and run into the hole. A downlog was recorded at a speed of $2800 \mathrm{ft} / \mathrm{h}$, reaching a depth of $699 \mathrm{~m}$ wireline log depth below seafloor (WSF) only a few meters above the total drilled depth (Fig. F30). The first uplog pass (the repeat pass) was recorded over a limited depth interval (699-366 m WSF) as a check for the repeatability of logging data. The tool string was run back to the bottom depth of $699 \mathrm{~m} \mathrm{WSF}$, and a full complete uplog pass (the main pass) was recorded, ending just above the seafloor. The tool string reached the rig floor and was rigged down at $0845 \mathrm{~h}$.

As the caliper measurement from the first logging run indicated that much of the borehole was $<14$ inches in diameter and thus suitable for a VSP experiment, the VSI tool string was the second run in Hole U1421A. Protected Species Observation began at $0715 \mathrm{~h}$, and the air gun ramp-up began $1 \mathrm{~h}$ later, as no protected species were observed in the $1410 \mathrm{~m}$ diameter exclusion zone for this site (see "Operations"). The air guns were positioned $\sim 3 \mathrm{~m}$ below the sea surface for the VSP, as the subseafloor targets were relatively shallow, and the hydrophone was suspended $2 \mathrm{~m}$ below the air guns. Rig up of the VSI tool string began at $0845 \mathrm{~h}$, and the tool string was run into the hole, reaching total depth at $1150 \mathrm{~h}$. Shots were fired at nine depth stations in the open borehole, and six of the station locations yielded reasonable first arrivals. The recorded waveforms at the shallowest depth stations were noisy, likely because of unconsolidated sediment that prevented the VSI caliper from making firm contact with the borehole wall. The tool string was pulled back into the pipe at the end of the VSP and reached the rig floor at 1549 h. Rig down was complete at $1625 \mathrm{~h}$, which concluded logging operations for Site U1421 and Expedition 341. During logging operations in Hole $\mathrm{U} 1421 \mathrm{~A}$, heave ranged from $\sim 0.8$ to $2.0 \mathrm{~m}$ (peak to peak).

\section{Data processing and quality assessment}

Logging data were depth-matched using the resistivity measurement from the main pass of the Sonic-in- duction tool string as a reference log, allowing a unified depth scale to be produced. Logging data were then depth-shifted to the seafloor reference frame based on the step increase observed in gamma ray from the main pass of the Sonic-induction tool string. The seafloor was recorded at $729 \mathrm{~m}$ wireline log depth below rig floor (WRF) and the resulting depth scale is wireline log matched depth below seafloor (WMSF).

Figures F31, F32, F33, and F34 show the main logging data recorded in Hole U1421A. The log data are good quality, likely because of the relatively smooth borehole wall, as shown by the caliper measurements from the Sonic-induction tool string (Fig. F31). With the exception of some thin washouts, borehole diameter varied smoothly and rarely exceeded 18 inches, the limit of the HLDS caliper arm. The character of the borehole wall in Hole U1421A on the upper continental slope is a distinct change from the rugose character observed at the deeper water sites (U1417 and U1418). Above $500 \mathrm{~m}$ WMSF, borehole diameter ranges from 10 to 17 inches with an average diameter of $\sim 15$ inches. The only exception is one narrow spot indicated by the caliper log at $\sim 300 \mathrm{~m}$ WMSF. The hole was nearly in gauge below $\sim 500 \mathrm{~m}$ WMSF, with the exception of a washedout zone between 583 and $591 \mathrm{~m}$ WMSF.

The medium and deep resistivity curves show the same trends downhole and are very close in value (Fig. F31), indicating good-quality resistivity data. There is a distinct separation between the shallow resistivity curve and the medium and deep resistivity curves through much of the logged interval. Given that the borehole diameter is within the depth of investigation of all three curves, this separation could indicate that the shallow borehole wall may be invaded by logging mud or imply the presence of a mud cake, which has relatively low resistivity. Although porosity data from Site U1421 cores are limited, relatively high porosity values were measured in recovered material (24\%-56\%; see "Physical properties"), which would be consistent with shallow mud invasion of the borehole wall during logging operations.

The DSI recorded P\&S monopole and lower and upper dipole modes in Hole U1421A, with standard (high) frequency for the monopole and upper dipole and low frequency for the lower dipole. High coherence in sonic waveforms is indicated by orange to red areas in the compressional velocity $\left(V_{\mathrm{P}}\right)$ and flexural velocity $\left(V_{S}\right)$ tracks in Figure F31. These data indicate that the DSI was successful in capturing clear compressional arrivals through the entire logged in- 
terval. Coherence in the flexural arrivals is spotty in the upper half of the logged interval but higher deeper than $440 \mathrm{~m}$ WMSF.

A comparison between the main pass and repeat pass of the Sonic-induction tool string shows excellent agreement for all measurements (Fig. F32). This agreement provides further evidence that log data quality is good for this site.

Core recovery was limited at Site U1421, preventing a direct comparison with logs for most of the logged interval. However, gamma ray data were recorded through the drill pipe at Hole U1421A in an interval where core recovery was high. The gamma ray measurement is highly attenuated when the logging tool is inside the BHA (above $96 \mathrm{~m}$ WMSF in this hole). Despite the log signal attenuation and a slight $(<1 \mathrm{~m})$ depth offset between log and core data, there is still reasonable agreement in NGR between logs and cores (Fig. F33). Variations observed in total gamma radiation could be linked to lithology in this interval, with lower gamma radiation corresponding to diatom-rich sediment in the core and higher gamma radiation corresponding to layers with low microfossil content (see "Lithostratigraphy" for description of diatom-bearing mud).

\section{Logging stratigraphy}

The logged interval in Hole U1421A is divided into four units based on distinct changes in character and trends in gamma radiation, resistivity, and $P$-wave velocity data (Fig. F31). Gamma radiation shows downhole variability but no consistent trend with depth. Resistivity and $P$-wave velocity show very similar variations through the entire borehole. $P$ wave velocity generally increases downhole, consistent with a typical compaction trend with depth.

\section{Logging Unit 1 (base of pipe to 202 m WMSF)}

Logging Unit 1 does not display any trends with depth for all log curves (Fig. F31). Gamma ray values are relatively high, with an average value of $\sim 43$ gAPI. Values decrease slightly from $\sim 170 \mathrm{~m}$ WMSF to the base of the unit. Resistivity and $P$-wave velocity data both vary around mean values, $\sim 3.6 \Omega \mathrm{m}$ for medium and deep resistivity and $\sim 1900 \mathrm{~m} / \mathrm{s}$ for $P$-wave velocity.

\section{Logging Unit 2 (202-433 m WMSF)}

Logging Unit 2 is distinguished by a general decrease in gamma ray values and increased variability in all log data (Fig. F31). Within this unit, gamma ray values range from 26 to 60 gAPI, with an abrupt increase at $\sim 298 \mathrm{~m}$ WMSF. Both resistivity and $P$-wave velocity show two distinct trends within the unit: in- tervals of high, relatively constant values (e.g., 220$290 \mathrm{~m}$ WMSF) separated by intervals of very low values (e.g., 290-302 m WMSF). Deep resistivity values range from 1.7 to $5.2 \Omega \mathrm{m}$. $P$-wave velocities range from $\sim 1600 \mathrm{~m} / \mathrm{s}$ in the low intervals to as high as $\sim 2400 \mathrm{~m} / \mathrm{s}$.

\section{Logging Unit 3 (433-625 m WMSF)}

The boundary between logging Units 2 and 3 is marked by a dramatic decrease in resistivity and velocity (Fig. F31). Logging Unit 3 is characterized by the greatest fluctuations in borehole diameter, gamma radiation, resistivity, and $P$-wave velocity compared to all other logging units. A series of thin $(<5 \mathrm{~m})$ washouts are observed in the shallowest $70 \mathrm{~m}$ of this unit, and one thick $(\sim 10 \mathrm{~m})$ washed-out interval is recorded in the caliper log between 583 and $591 \mathrm{~m}$ WMSF. Gamma ray values range from 17 to 55 gAPI, with the lowest values associated with washed-out intervals. Deep resistivity values range from 1.2 to $6.4 \Omega \mathrm{m}$, and velocities range from $\sim 1600$ to $2600 \mathrm{~m} / \mathrm{s}$.

\section{Logging Unit 4 (625-699 m WMSF [base of logged interval])}

Logging Unit 4 is characterized by distinctly less emergent resistivity and $P$-wave velocity data (Fig. F31). The average gamma ray value in this unit is 39 gAPI. Deep resistivity values are similar to values in logging Unit 1 and the high-resistivity plateaus in logging Unit 2 , with typical values of $\sim 4 \Omega \mathrm{m}$. $P$-wave velocity is relatively high, with an average value of $2300 \mathrm{~m} / \mathrm{s}$.

\section{Vertical seismic profile}

The VSP in Hole U1421A establishes a link between core and log data (recorded in depth) and seismic surveys (recorded in two-way traveltime) at the location of the borehole. Data acquired during the VSP are summarized in Table T12 and Figures F30 and F34.

Six out of nine stations yielded reasonable traveltimes, ranging from $1.278 \mathrm{~s}$ two-way traveltime below sea level at $284.7 \mathrm{~m}$ WMSF to $1.641 \mathrm{~s}$ at the deepest station at $687 \mathrm{~m}$ WMSF. Many of the seismic waveforms at shallower stations were noisy, but the waveform stacks from these six stations appear to be good. Table T12 lists measured and corrected arrival times. Measured traveltimes are the differences between the arrival of the acoustic pulse at a hydrophone located directly below the air gun array and the arrival at the borehole receiver. Corrected traveltimes are the times from the sea surface to the borehole receiver and account for the depth of the air 
guns ( $3 \mathrm{~m}$ below sea level for Hole U1421A) and for the depth of the hydrophone below the air guns ( 2 $\mathrm{m})$. A linear trend is observed in the traveltime data, consistent with the increase in $P$-wave velocity with depth (Fig. F31).

\section{Core-log-seismic integration}

For the purposes of shipboard data correlation at Site U1421, we compared data displayed in the following two depth scales: WMSF (see "Downhole logging") and CSF-A for logging and core data, respectively. Logging data were depth-matched between different tool strings using the gamma ray and resistivity logs recorded on each logging run and then shifted to the WMSF depth scale (see "Downhole logging" in the "Methods" chapter [Jaeger et al., 2014]). Logging data were recorded in Hole U1421A (see "Downhole logging"). Core physical properties were measured on cores from Holes U1421A-U1421C (see "Physical properties"), but because of the shallow total depths of Holes U1421B and U1421C (shallower than $40 \mathrm{~m}$ CSF-A), the majority of the data compared here were measured in the deepest hole, Hole U1421A.

For preliminary correlation between Site U1421 lithostratigraphic and logging units with features observed in seismic data, we converted lithostratigraphic and logging unit boundaries from depth in meters CSF-A/WMSF to two-way traveltime using the average velocity of each unit. In the shallowest 95 $\mathrm{m}$ of the hole, average $P$-wave velocity was derived from core physical properties measurements using data from the PWC within lithostratigraphic Unit I and the core PWL in the shallowest section of lithostratigraphic Unit II (see "Physical properties"). Deeper than $\sim 95 \mathrm{~m}$ CSF-A/WMSF, average $P$-wave velocity was derived from downhole sonic logging data (see "Downhole logging"). Detailed correlations for this site using fully integrated velocity measurements will require postcruise research.

\section{Lithostratigraphy-downhole logging data correlation}

Sediment core descriptions and downhole logging data obtained from Site U1421 were combined in order to examine the similarities and differences between the different data sets. We compared the lithostratigraphic units and recovered sediment with logging data recorded with the Sonic-induction tool string between $~ 95$ and $700 \mathrm{~m}$ WMSF (see "Downhole logging"). Because of poor core recovery throughout the interval, identifying clear correlations is difficult. Nevertheless, we observed three areas of very low gamma ray and resistivity data that likely correspond to three prominent bioturbated diatom ooze intervals at 300-310, 490-510, and 600-610 m CSF-A in the core (Fig. F35). Another interval characterized by low gamma ray and resistivity data between 430 and $460 \mathrm{~m}$ WMSF could similarly correspond to a diatom ooze lithology. These low gamma ray features also correspond to washed-out intervals in the borehole at $\sim 300, \sim 495$, and $\sim 590 \mathrm{~m}$ WMSF. Similar observations were made at Site U1418, which supports the interpretation that borehole size is influenced by the lithology. Based on these observations, the interpreted vertical offset between these features in cores and logs is $\sim 13 \mathrm{~m}$ and is the same for all correlated biogenic units.

\section{Physical properties-downhole logging data correlation}

Although core-log comparison is limited by poor core recovery through most of the borehole, there is a similarity in general trends and features between core physical properties and log data where they overlap (Fig. F36). Core recovery was most complete in the upper $\sim 100 \mathrm{~m}$ at this site, but this depth interval is typically not logged because of the placement of the drill pipe during logging operations (see "Downhole logging"). However, gamma ray data recorded through the drill pipe in Hole U1421A allow a relative comparison of logging data with core NGR data. The log gamma ray signal, though highly attenuated by the pipe, shows elevated values, increasing with depth, between the seafloor and $\sim 18 \mathrm{~m}$ WMSF. There is a similar increase in the core NGR values; these data have been corrected for volume using GRA density. Gamma ray values drop sharply deeper than $\sim 20 \mathrm{~m}$ in both $\log$ (WMSF) and core (CSF-A) depth scales. It is difficult to establish whether there is a depth offset between core and log data in this shallow interval, but detailed comparison of the in-pipe gamma ray log with NGR suggests a potential offset of 0 to $2 \mathrm{~m}$ (see "Downhole logging;" Fig. F33). One potential explanation for a reduced offset shallow in the borehole $(<2 \mathrm{~m})$ versus greater offset deeper in the hole (perhaps $13 \mathrm{~m}$ based on correlated biogenic units) is that there is some cumulative offset with depth. Below $\sim 100 \mathrm{~m}$ CSF-A/WMSF, where core recovery drops to an average value of $\leq 10 \%$, there are no distinct features in the core NGR data to compare with logging data.

The $P$-wave velocity $\log$ indicates generally higher formation velocities than core-based velocity measurements from Site U1421 (Fig. F36). In the interval between $\sim 60$ and $95 \mathrm{~m}$ CSF-A (the deepest PWL measurements), the typical $P$-wave velocity measured on the core with the WRMSL PWL is fairly consistent with the $P$-wave velocity $\log$ in the shallower section 
of the logged interval of the borehole (Fig. F37). Discrete PWC measurements on cores, collected through the entire cored interval where recovery permitted, generally show lower velocity values than core PWL and the velocity log. This discrepancy is likely related to poor core recovery, leading to discrete measurements being biased toward the properties of easier to recover lithologies. In addition, discrete PWC measurements are point samples, whereas the downhole velocity log integrates potentially lower velocity matrix and potentially higher velocity clasts. Discrete $P$-wave data show similar trends to the velocity $\log$, in particular capturing a lower velocity interval between 490 and $500 \mathrm{~m}$ CSF-A/WMSF and an increasing trend in velocity with depth between $~ 595$ and $670 \mathrm{~m}$ CSF-A/WMSF. The high quality of the sonic logs acquired in Hole U1421A (see "Downhole logging") suggests that these data will be valuable for more detailed postcruise correlations between borehole data and seismic images.

\section{Seismic sequences and correlation with lithostratigraphy and downhole logs}

Two seismic profiles cross Site U1421: GOA2503 (Fig. F3), acquired in 2004 aboard the R/V Maurice Ewing, and STEEP07 (Fig. F1), acquired in 2008 aboard the $\mathrm{R} / \mathrm{V}$ Marcus Langseth. In preparation for core-log-seismic integration, we interpreted key seismic horizons that mark a change in acoustic facies or a reflector truncation surface. Horizons $\mathrm{H} 1, \mathrm{H} 2$, and $\mathrm{H} 3$ were previously interpreted by Worthington et al. (2008, 2010). Here, we name subhorizons using the Worthington et al. $(2008,2010)$ naming convention. Additional internal packages are broken out, defined either by a high-amplitude, continuous reflector or a minor change in seismic character.

The seismic profiles capture the correlative slope facies of the sequences imaged on the shelf near Site U1420 (Figs. F37, F38). At Site U1421, Horizon H1 denotes the correlative conformity associated with the shelf unconformity seen at Site U1420. The lithostratigraphic Unit I/II boundary (57 m CSF-A) and the logging Unit $1 / 2$ boundary (202 m WMSF) correlate to traveltime positions shallower than Horizon H1. Lithostratigraphic Unit I is characterized by a massive clast-rich diamict. The lithostratigraphic Unit I/II boundary is therefore likely located within a package of semichaotic, high-amplitude reflectors (Fig. F37). In lithostratigraphic Unit II, there are multiple intervals in which core recovery is $<10 \%$ and the recovered material consists primarily of washed pebbles and drilled clasts of varying lithologies (see "Lithostratigraphy"). The logging Unit $1 / 2$ boundary maps to the bottom of a semiparallel, high-amplitude package. Below this package is a sec- tion of acoustically semitransparent and semichaotic character (Fig. F37).

Using the sonic log for two-way traveltime-depth conversions, we correlated the remaining logging unit boundaries with the seismic data (Fig. F37). Further investigation, including developing synthetic seismograms, is required for more definitive correlation. The logging Unit 2/3 boundary, defined by significant decreases in velocity and resistivity (see "Downhole logging"), may coincide with a horizon within a high-amplitude package above Horizon H2A (Fig. F37). The logging Unit 3/4 boundary, defined by increases in velocity and resistivity and a change in log character (see "Downhole logging"), appears to correlate within the semitransparent facies between Horizons $\mathrm{H} 2 \mathrm{~A}$ and H2B. The base of logging Unit 4 and the deepest drilled depth in Hole U1421A coincide with the top of Horizon H2B, which is a high-amplitude reflector that separates two semitransparent facies with internal parallel structure.

\section{References}

Addison, J.A., Finney, B.P., Dean, W.E., Davies, M.H., Mix, A.C., Stoner, J.S., and Jaeger, J.M., 2012. Productivity and sedimentary $\delta^{15} \mathrm{~N}$ variability for the last 17,000 years along the northern Gulf of Alaska continental slope. Paleoceanography, 27(1):PA1206. doi:10.1029/ 2011PA002161

Bergen, F.W., and O'Neil, P., 1979. Distribution of Holocene foraminifera in the Gulf of Alaska. J. Paleontol., 53(6):1267-1292. http://www.jstor.org/stable/ 1304134

Berger, A.L., Gulick, S.P.S., Spotila, J.A., Upton, P., Jaeger, J.M., Chapman, J.B., Worthington, L.A., Pavlis, T.L., Ridgway, K.D., Willems, B.A., and McAleer, R.J., 2008. Quaternary tectonic response to intensified glacial erosion in an orogenic wedge. Nat. Geosci., 1:793-799. doi:10.1038/ngeo334

Boltovskoy, D., Kling, S.A., Takahashi, K., and Bjørklund, K., 2010. World atlas of distribution of Recent polycystina (Radiolaria). Palaeontol. Electron., 13:1-229. http:// palaeo-electronica.org/2010_3/215/index.html

Brzezinski, M.A., Villareal, T.A., and Lipschultz, F., 1998. Silica production and the contribution of diatoms to new and primary production in the central North Pacific. Mar. Ecol.: Prog. Ser., 167:89-104. doi:10.3354/ meps 167089

Cande, S.C., and Kent, D.V., 1995. Revised calibration of the geomagnetic polarity timescale for the Late Cretaceous and Cenozoic. J. Geophys. Res.: Solid Earth, 100(B4):6093-6095. doi:10.1029/94JB03098

Davies, M.H., Mix, A.C., Stoner, J.S., Addison, J.A., Jaeger, J., Finney, B., and Wiest, J., 2011. The deglacial transition on the southeastern Alaskan margin: meltwater input, sea level rise, marine productivity, and sedimen- 
tary anoxia. Paleoceanography, 26(2):PA2223. doi:10.1029/2010PA002051

DeFoor, W., Person, M., Larsen, H.C., Lizarralde, D., Cohen, D., and Dugan, B., 2011. Ice sheet-derived submarine groundwater discharge on Greenland's continental shelf. Water Resour. Res., 47(7):W07549. doi:10.1029/2011WR010536

Dugdale, R.C., Wilkerson, F.P., and Minas, H.J., 1995. The role of a silicate pump in driving new production. DeepSea Res., Part 1, 42(5):697-719. doi:10.1016/09670637(95)00015-X

Gasser, D., Bruand, E., Stüwe, K., Foster, D.A., Schuster, R., Fügenschuh, B., and Pavlis, T., 2011. Formation of a metamorphic complex along an obliquely convergent margin: structural and thermochronological evolution of the Chugach Metamorphic Complex, southern Alaska. Tectonics, 30(2):TC2012. doi:10.1029/ 2010TC002776

Gieskes, J.M., Schrag, D., Chan, L.-H., Zhang, L., and Murray, R.W., 1998. Geochemistry of interstitial waters. In Saunders, A.D., Larsen, H.C., and Wise, S.W., Jr. (Eds.), Proc. ODP, Sci. Results, 152: College Station, TX (Ocean Drilling Program), 293-305. doi:10.2973/ odp.proc.sr.152.228.1998

Hamme, R.C., Webley, P.W., Crawford, W.R., Whitney, F.A., DeGrandpre, M.D., Emerson, S.R., Eriksen, C.C., Giesbrecht, K.E., Gower, J.F.R., Kavanaugh, M.T., Peña, M.A., Sabine, C.L., Batten, S.D., Coogan, L.A., Grundle, D.S., and Lockwood, D., 2010. Volcanic ash fuels anomalous plankton bloom in subarctic northeast Pacific. Geophys. Res. Lett., 37(19):L19604. doi:10.1029/2010GL044629

Hasle, G.R., and Syvertsen, E.E., 1996. Marine diatoms. In Tomas, C.R. (Ed.), Identifying Marine Diatoms and Dinoflagellates: San Diego (Academic Press), 5-385. doi:10.1016/B978-012693015-3/50005-X

Hedges, J.I., Clark, W.A., Quay, P.D., Richey, J.E., Devol, A.H., and Santos, U.D., 1986. Compositions and fluxes of particulate organic material in the Amazon River. Limnol. Oceanogr., 31(4):717-738. doi:10.4319/ 10.1986.31.4.0717

Hesse, R., 2003. Pore water anomalies of submarine gashydrate zones as tool to assess hydrate abundance and distribution in the subsurface-what have we learned in the past decade? Earth-Sci. Rev., 61(1-2):149-179. doi:10.1016/S0012-8252(02)00117-4

Hilgen, F.J., Lourens, L.J., and Van Dam, J.A., 2012. The Neogene period. In Gradstein, F.M., Ogg, J.G., Schmitz, M.D., and Ogg, G.M. (Eds.), The Geologic Time Scale: Oxford (Elsevier), 923-978. doi:10.1016/B978-0-44459425-9.00029-9

Jaeger, J.M., Gulick, S.P.S., LeVay, L.J., Asahi, H., Bahlburg, H., Belanger, C.L., Berbel, G.B.B., Childress, L.B., Cowan, E.A., Drab, L., Forwick, M., Fukumura, A., Ge, S., Gupta, S.M., Kioka, A., Konno, S., März, C.E., Matsuzaki, K.M., McClymont, E.L., Mix, A.C., Moy, C.M., Müller, J., Nakamura, A., Ojima, T., Ridgway, K.D., Rodrigues Ribeiro, F., Romero, O.E., Slagle, A.L., Stoner, J.S., St-Onge, G., Suto, I., Walczak, M.H., and Worthington, L.L., 2014. Methods. In Jaeger, J.M., Gulick, S.P.S., LeVay, L.J., and the Expedition 341 Scientists, Proc.
IODP, 341: College Station, TX (Integrated Ocean Drilling Program). doi:10.2204/iodp.proc.341.102.2014

Kucera, M., and Kennett, J.P., 2000. Biochronology and evolutionary implications of late Neogene California margin planktonic foraminiferal events. Mar. Micropaleontol., 40(1-2):67-81. doi:10.1016/

S0377-8398(00)00029-3

Lu, Z., Rickaby, R.E.M., Wellner, J., Georg, B., Charnley, N., Anderson, J.B., and Hensen, C., 2010. Pore fluid modeling approach to identify recent meltwater signals on the west Antarctic Peninsula. Geochem., Geophys., Geosyst., 11(6):Q06017. doi:10.1029/2009GC002949

Medlin, L.K., and Priddle, J. (Eds.), 1990. Polar Marine Diatoms: Cambridge (British Antarct. Surv.).

Molnia, B.F., and Hein, J.R., 1982. Clay mineralogy of a glacially dominated, subarctic continental shelf: northeastern Gulf of Alaska. J. Sediment. Petrol., 52(2):515527. doi:10.1306/212F7F90-2B24-11D78648000102C1865D

Plafker, G., 1987. Regional geology and petroleum potential of the northern Gulf of Alaska continental margin. In Scholl, D.W., Grantz, A., and Vedder, J.G. (Eds.), Petroleum Geology Potential of the Continental Margin of Western North America and Adjacent Ocean Basins. Earth Sci. Ser. (N. Y.), 6:229-268.

Plafker, G., Moore, J.C., and Winkler, G.R., 1994. Geology of the southern Alaska margin. In Plafker, G., and Berg, H.C. (Eds.), The Geology of North America (Vol. G): The Geology of Alaska: Boulder, CO (Geol. Soc. Am.), 389449.

Powell, R.D., and Cooper, J.M., 2002. A glacial sequence stratigraphic model for temperate, glaciated continental shelves. In Dowdeswell, J.A., and Ó'Cofaigh, C. (Eds.), Glacier-Influenced Sedimentation on High-Latitude Continental Margins. Geol. Soc. Spec. Publ., 203:215-244. doi:10.1144/GSL.SP.2002.203.01.12

Powell, R.D., and Molnia, B.F., 1989. Glacimarine sedimentatary processes, facies and morphology of the southsoutheast Alaska shelf and fjords. Mar. Geol., 85(24):359-390. doi:10.1016/0025-3227(89)90160-6

Saffer, D.M., and McKiernan, A.W., 2009. Evaluation of in situ smectite dehydration as a pore water freshening mechanism in the Nankai Trough, offshore southwest Japan. Geochem., Geophys., Geosyst., 10(2):Q02010. doi:10.1029/2008GC002226

Sakshaug, E., 2004. Primary and secondary production in the Arctic Seas. In Stein, R., and Macdonald, R.W. (Eds.), The Organic Carbon Cycle in the Arctic Ocean: Heidelberg (Springer-Verlag), 57-82. doi:10.1007/978-3-64218912-8_3

Sancetta, C., 1982. Distribution of diatom species in surface sediments of the Bering and Okhotsk Seas. Micropaleontology, 28(3):221-257. doi:10.2307/1485181

Sisson, V.B., Poole, A.R., Harris, N.R., Cooper Burner, H., Pavlis, T.L., Copeland, P., Donelick, R.A., and McClelland, W., 2003. Geochemical and geochronologic constraints for genesis of a tonalite-trondhjemite suite and associated mafic intrusive rocks in the eastern Chugach Mountains, Alaska: a record of ridge-transform subduction. In Sisson, V.B., Roeske, S.M., and Pavlis, T.L. (Eds.), 
Geology of a Transpressional Orogen Developed During Ridge-Trench Interaction Along the North Pacific Margin: Spec. Pap.-Geol. Soc. Am., 371:293-326. doi:10.1130/ 0-8137-2371-X.293

Smith, W.O., Jr., Baumann, M.E.M., Wilson, D.L., and Aletsee, L., 1987. Phytoplankton biomass and productivity in the marginal ice zone of the Fram Strait during summer 1984. J. Geophys. Res.: Oceans, 92(C7):67776786. doi:10.1029/JC092iC07p06777

Torres, M.E., Teichert, B.M.A., Tréhu, A.M., Borowski, W., and Tomaru, H., 2004. Relationship of pore water freshening to accretionary processes in the Cascadia margin: fluid sources and gas hydrate abundance. Geophys. Res. Lett., 31:L22305. doi:10.1029/2004GL021219

Vorren, T.O., Laberg, J.S., Blaume, F., Dowdeswell, J.A., Kenyon, N.H., Mienert, J., Rumohr, J., and Werner, F., 1998. The Norwegian-Greenland Sea continental margins: morphology and late Quaternary sedimentary processes and environment. Quat. Sci. Rev., 17(1-3):273302. doi:10.1016/S0277-3791(97)00072-3

Walinsky, S.E., Prahl, F.G., Mix, A.C., Finney, B.P., Jaeger, J.M., and Rosen, G.P., 2009. Distribution and composi- tion of organic matter in surface sediments of coastal southeast Alaska. Cont. Shelf Res., 29(13):1565-1579. doi:10.1016/j.csr.2009.04.006

Worthington, L.L., Gulick, S.P.S., and Pavlis, T.L., 2008. Identifying active structures in the Kayak Island and Pamplona Zones: implications for offshore tectonics of the Yakutat microplate, Gulf of Alaska. In Freymueller, J.T., Haeussler, P.J., Wesson, R.L., and Ekström, G. (Eds.), Active Tectonics and Seismic Potential of Alaska. Geophys. Monogr., 179:257-268. doi:10.1029/179GM14

Worthington, L.L, Gulick, S.P.S., and Pavlis, T.L., 2010. Coupled stratigraphic and structural evolution of a glaciated orogenic wedge, offshore St. Elias orogen, Alaska. Tectonics, 29:TC6013-TC6039. doi:10.1029/2010TC002723

Yanagisawa, Y., and Akiba, F., 1998. Refined Neogene diatom biostratigraphy for the northwest Pacific around Japan, with an introduction of code numbers for selected diatom biohorizons. Chishitsugaku Zasshi, 104(6):395-414. doi:10.5575/geosoc.104.395

Publication: 22 November 2014 MS 341-107 
Figure F1. A. Uninterpreted (top) and interpreted (bottom) STEEP09 seismic line, showing mappable horizons through the Bering shelf region. Targets for Site U1421 include Horizon H1 and Horizon H2, which marks the cessation of movement on the Pamplona Zone structures beneath the Bering Trough. Colored lines (H1-H5) are regional horizons interpreted throughout the study area. Black horizons (A-F) are interpreted locally to define glacial depositional sequences in the upper $2 \mathrm{~s}$ of the record. VE = vertical exaggeration assuming 1500 $\mathrm{m} / \mathrm{s}$ sound velocity. BT1-BT4 = fault structures. B. Perspective view of the Bering Trough region, showing locations of the trough relative to active structures of the Pamplona Zone. Modified from Worthington et al. (2010). YAK-NA = Yakutat-North America.
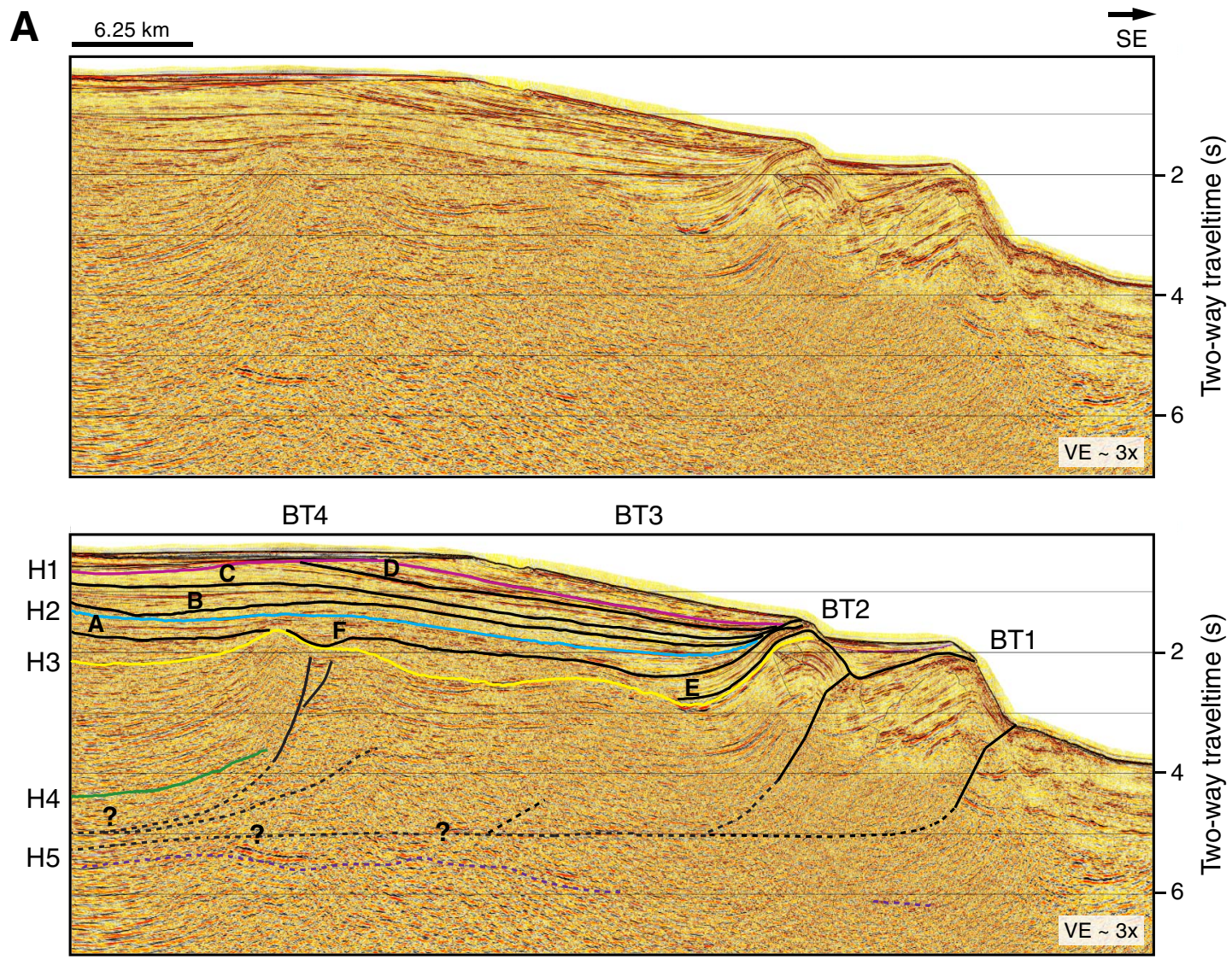

B

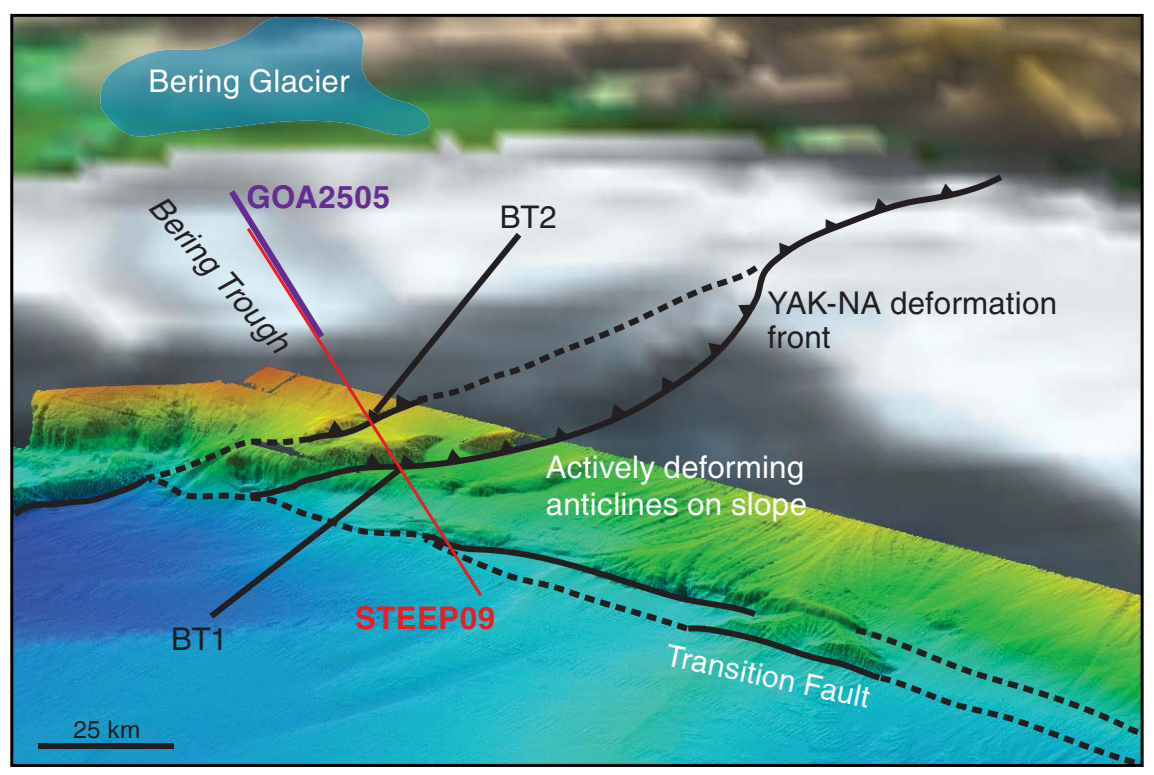


Figure F2. Uninterpreted (top) and interpreted (bottom) GOA-2505 seismic section. Interpreted section shows Structures BT4 and BT5 and key horizons. See Figure F1 for explanation of horizon delineation. VE = vertical exaggeration $1500 \mathrm{~m} / \mathrm{s}$ velocity. Proposed drilling depths for Sites U1420 and U1421 are shown. From Worthington et al. (2010).
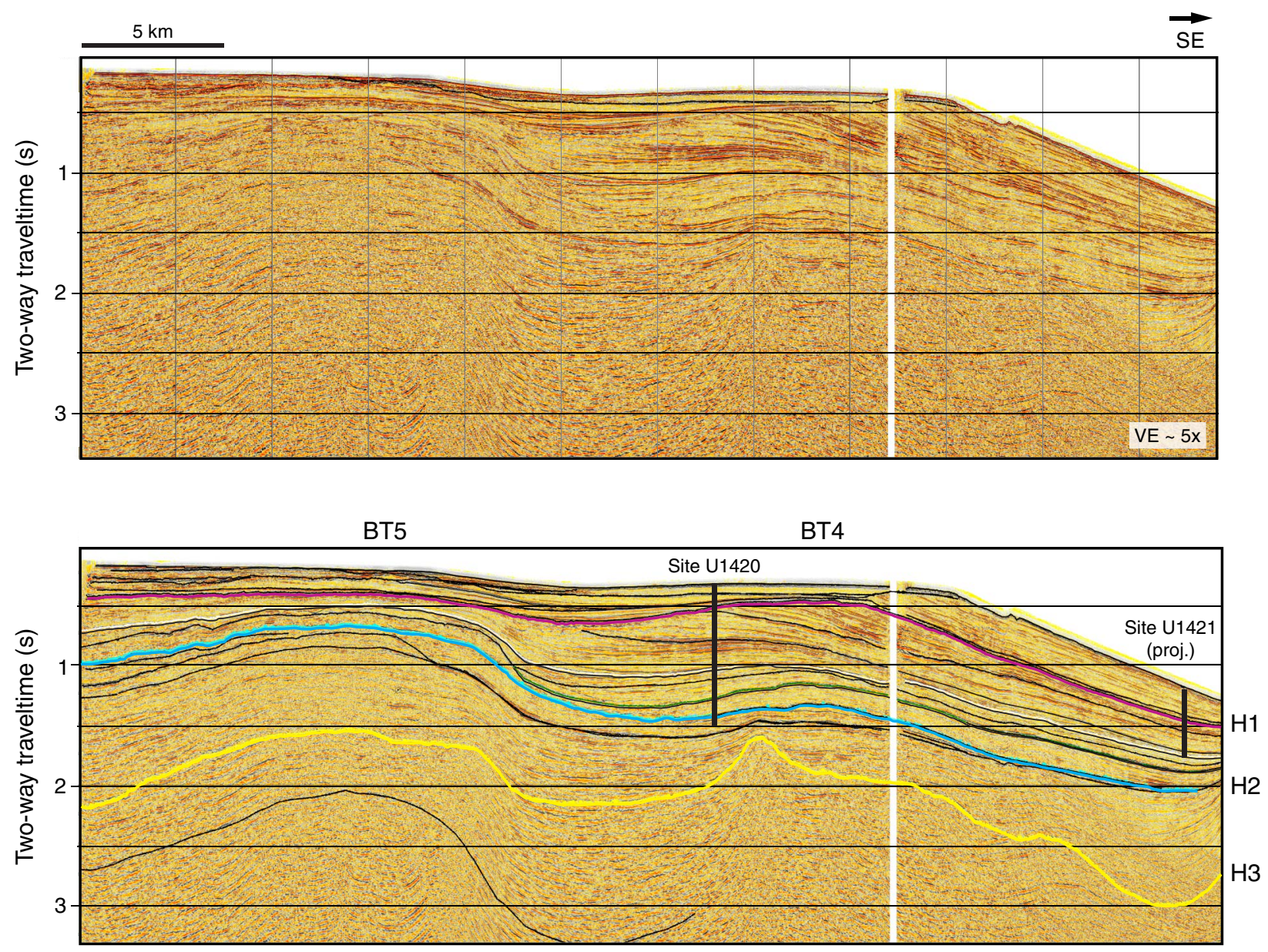
Figure F3. Hypothetical lithofacies motifs and facies succession for a continental slope, such as Site U1421, that may experience the full range of glacier ice advance-retreat cycles. Lithofacies are depicted using particle-size variations. Inferred depositional environment includes a continuum curve. Sediment accumulation rate is also inferred. IRD = ice-rafted debris. Modified after Powell and Cooper (2002).

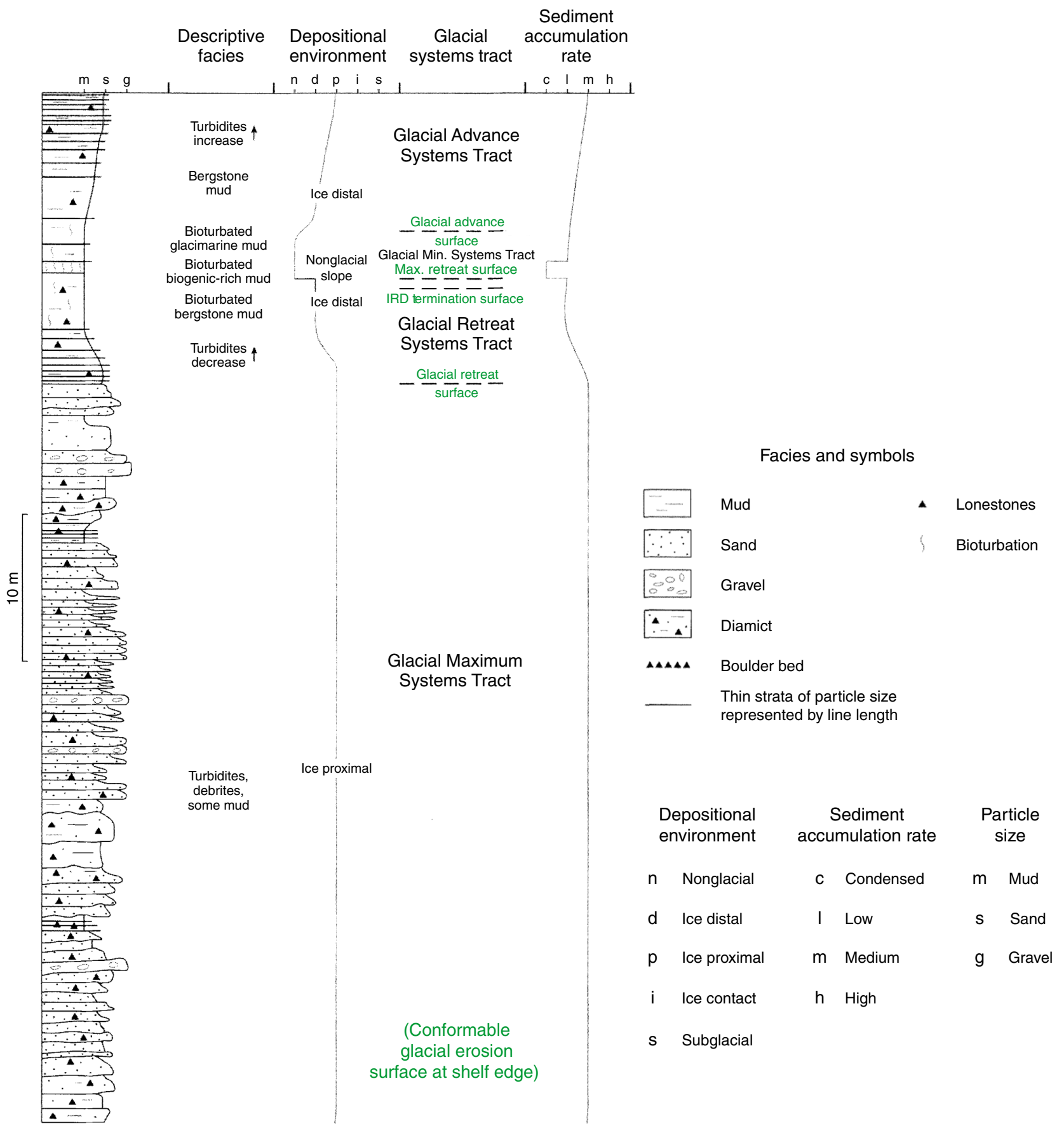


Figure F4. Core recovery, Site U1421.

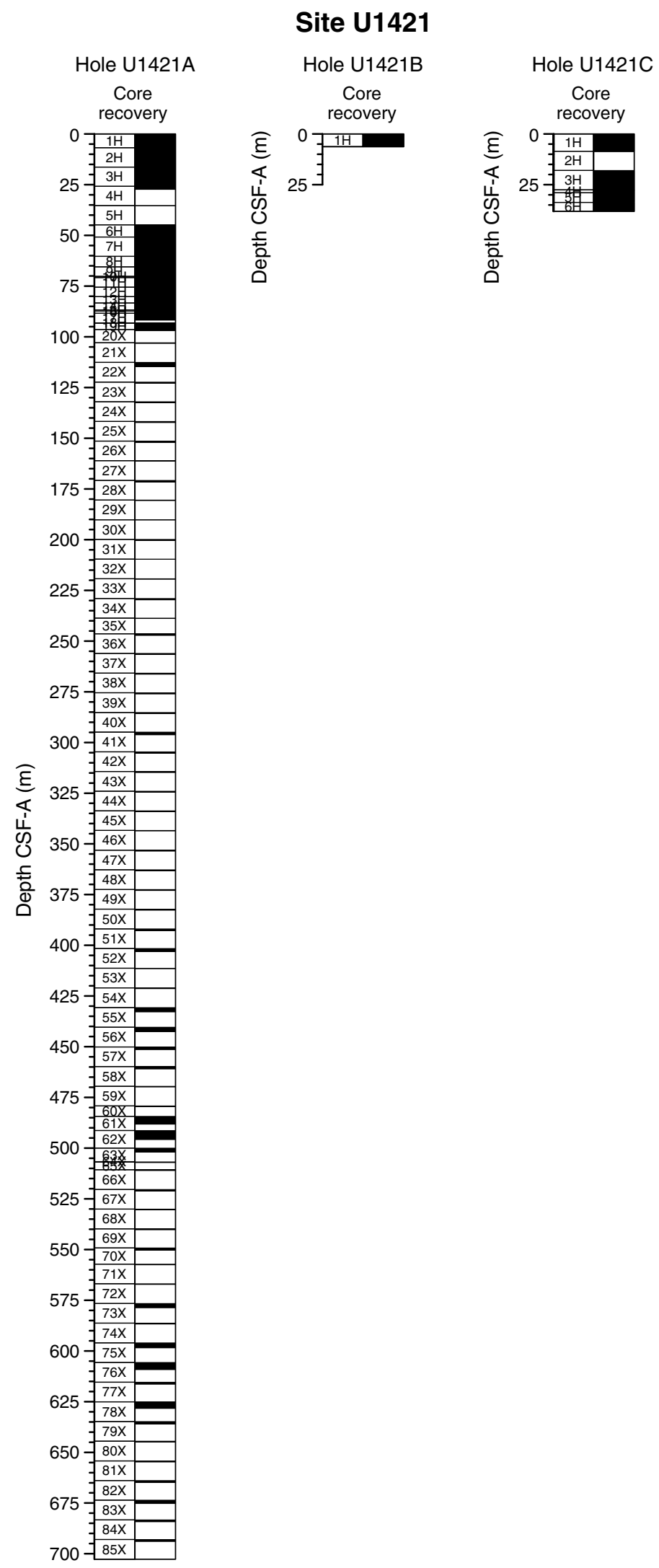


Figure F5. Hole summaries, Site U1421. Volcanic grain abundance: $1=$ trace, $2=$ volcaniclastic bearing, $3=$ volcaniclastic rich, $4=$ ash. GRA = gamma ray attenuation. A. Hole U1421A. (Continued on next two pages.)

A

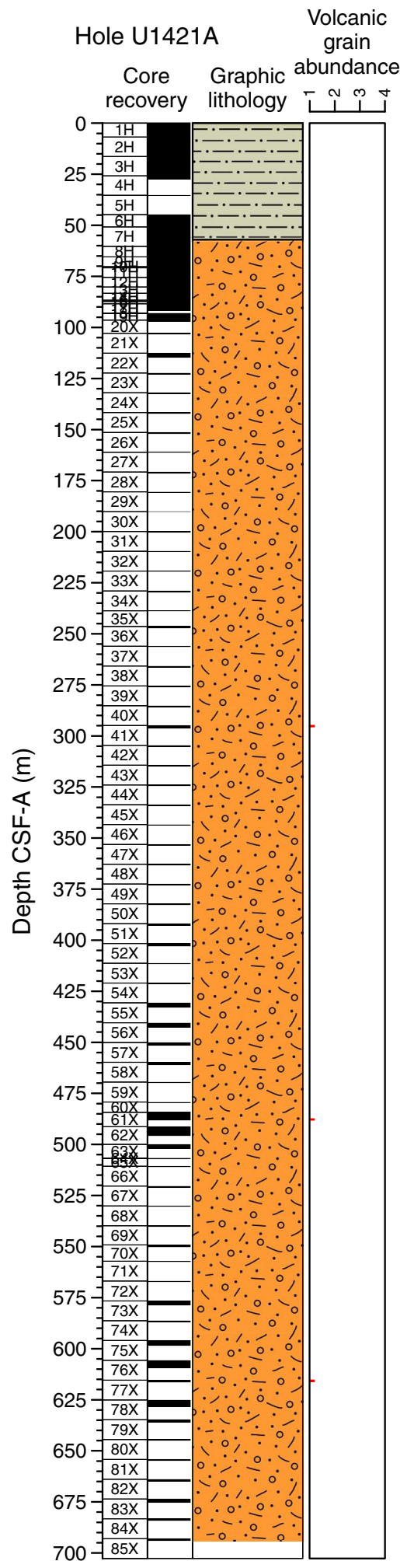

Magnetic susceptibility

(IU)

Unit description

unit Age

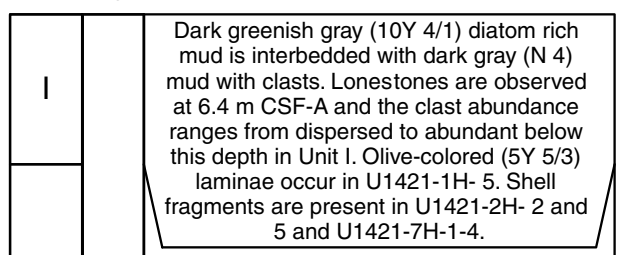

원 원 옹

سلسلسسلسا

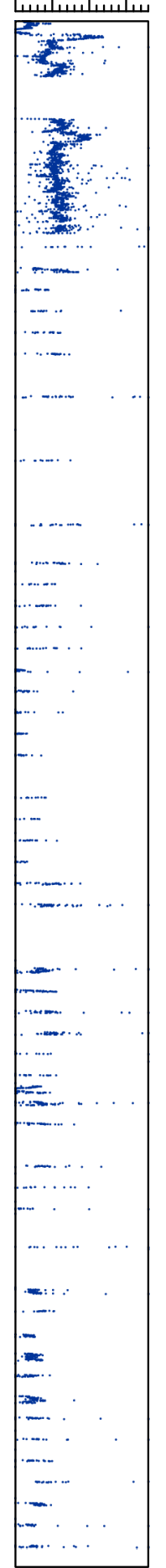

GRA

bulk density

$\left(\mathrm{g} / \mathrm{cm}^{3}\right)$

Color

reflectance

$b^{*}$

৫ํํ

سلسلسسلسأ للسلسسلسلس

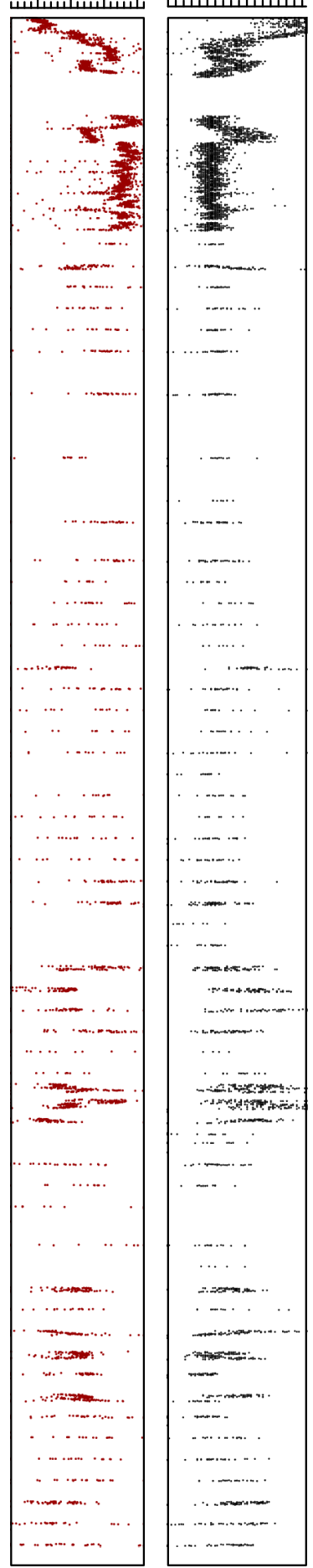


Figure F5 (continued). B. Hole U1421B. (Continued on next page.)

B

Hole U14121B $\begin{gathered}\text { Volcanic } \\ \text { grain }\end{gathered}$
Core Graphic abundance Lith.
recovery lithology

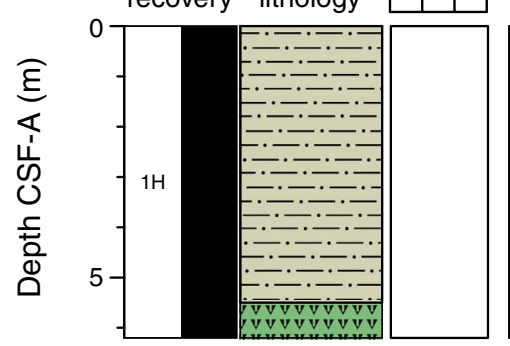

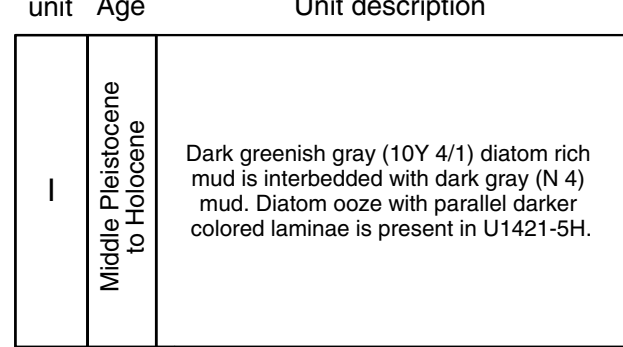

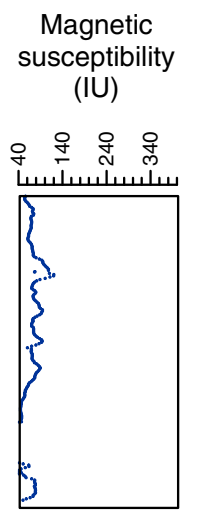

GRA

bulk density

$\left(\mathrm{g} / \mathrm{cm}^{3}\right)$

Color reflectance

$b^{*}$

인

سلَسلَسلسسأ للسلسلَسلَس
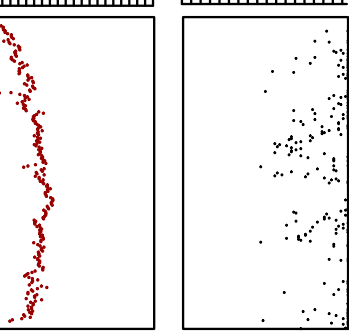
Figure F5 (continued). C. Hole U1421C.

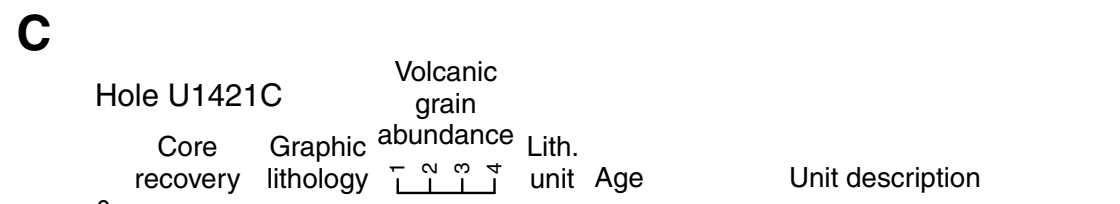


Figure F6. Examples of lithofacies of Site U1421. A. Dark greenish gray (10Y 4/1) diatom-bearing mud without lonestones (Facies F1b; interval 341-U1421A-1H-4, 30-35 cm). B. Dark greenish gray (10Y 4/1) diatom-bearing mud without lonestones with parallel laminations (Facies F1b; interval 341-U1421A-1H-5, 11-22 cm). C. Dark greenish gray (10Y 4/1) diatom-bearing mud with dispersed lonestones (Facies F1a; interval 341-U1421A-41X1, 51-60 cm). D. Dark greenish gray (10Y 4/1) laminated diatom ooze (Facies F5a; interval 341-U1421A-63X-1, 70-79 cm). E. Very dark gray (N 3) silty mud with common clasts (Facies F1a; interval U1421A-2H-7A, 18-26 $\mathrm{cm}$ ). F. Very dark gray (N 3) clast-poor diamict (Facies F4e; interval 341-U1421A-9H-3A, 54-62 cm). G. Very dark gray (N 3) clast-rich diamict (Facies F4f; interval 341-U1421A-36X-1A, 54-69 cm). H. Dark gray (N 4) to dark greenish gray (10Y 4/1) mud with biosilica and dispersed clasts (Facies F5b; interval 341-U1421A-22X-2A, 1-8 $\mathrm{cm})$. I. Dark greenish gray (10Y 4/1) diatom ooze with interbedded dark gray (N 4) mud with dispersed clasts (Facies F5a and F1a; interval 341-U1421A-63X-1A, 60-68 cm). J. Very dark gray (N 3) clast-rich diamict overlain by very dark gray (N 3) mud with soft-sediment deformation (Facies F4f and F1a; interval 341-U1421A-61X-2A, $103-121 \mathrm{~cm})$.

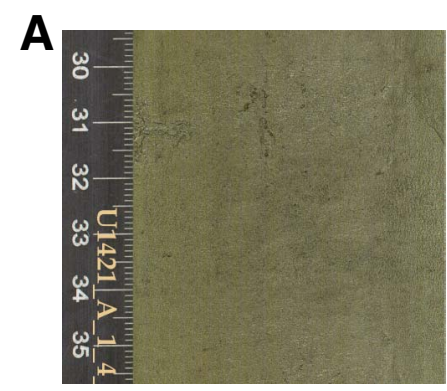

B

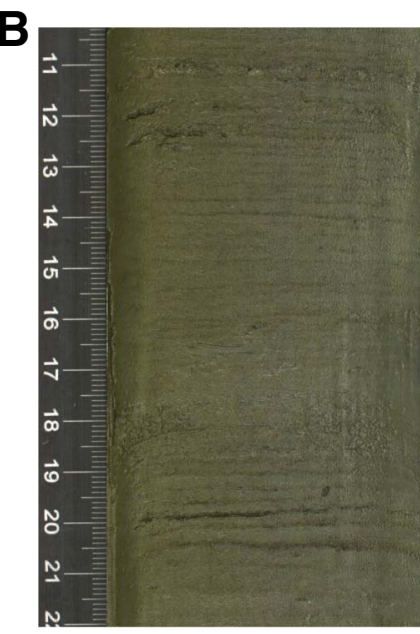

C

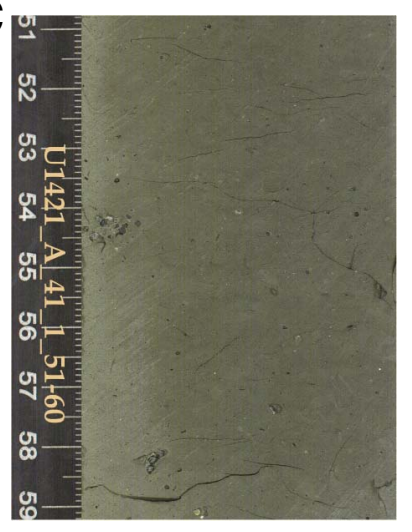

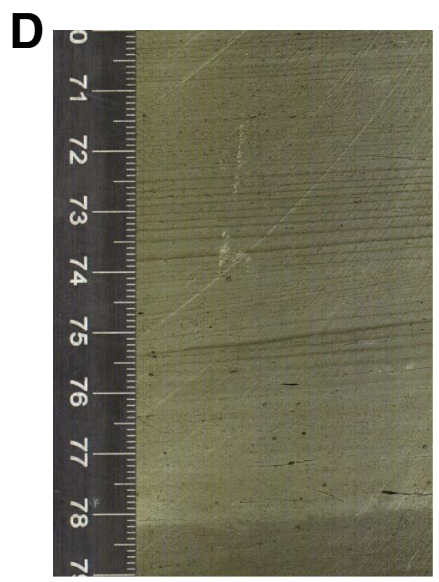

E

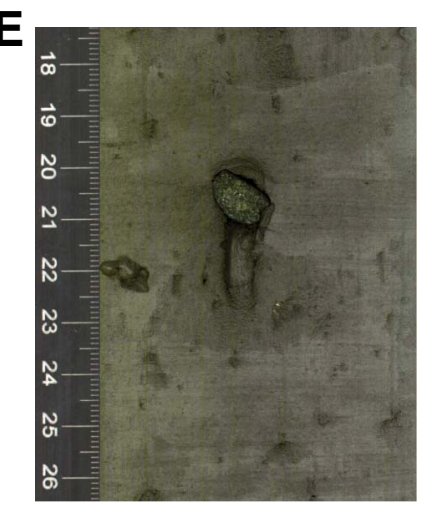

$\mathbf{F}$

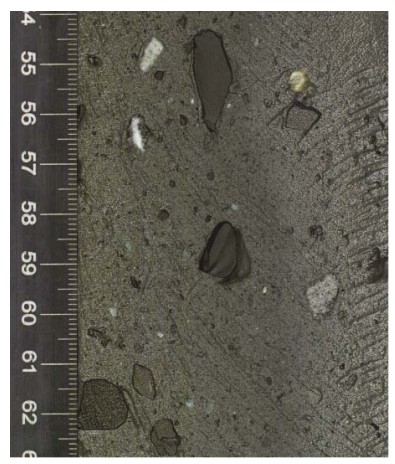

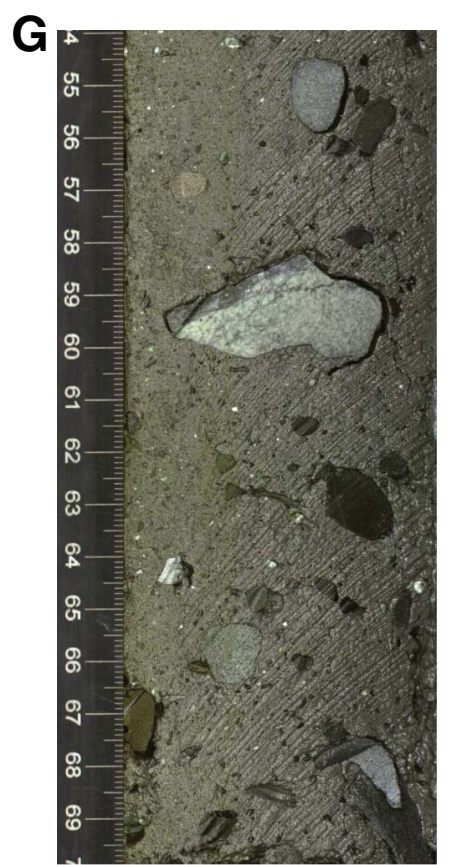

H

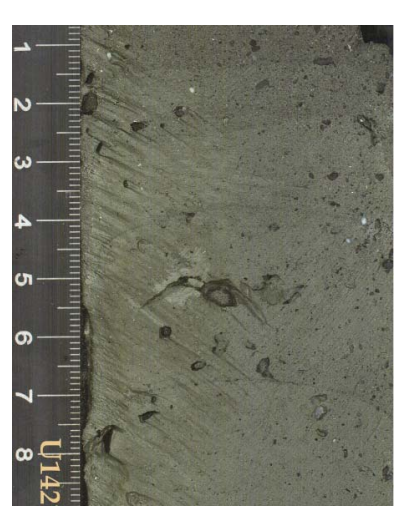

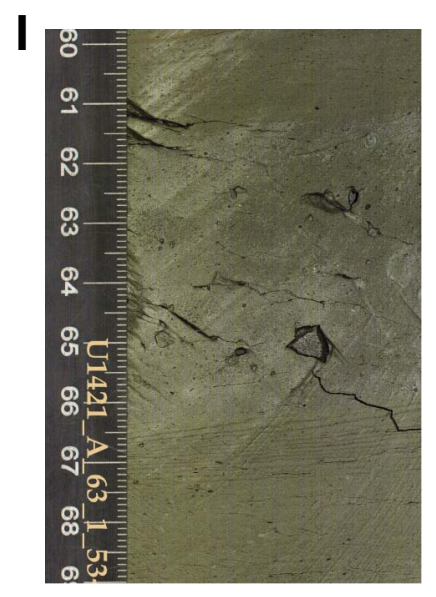

$\mathbf{J}$

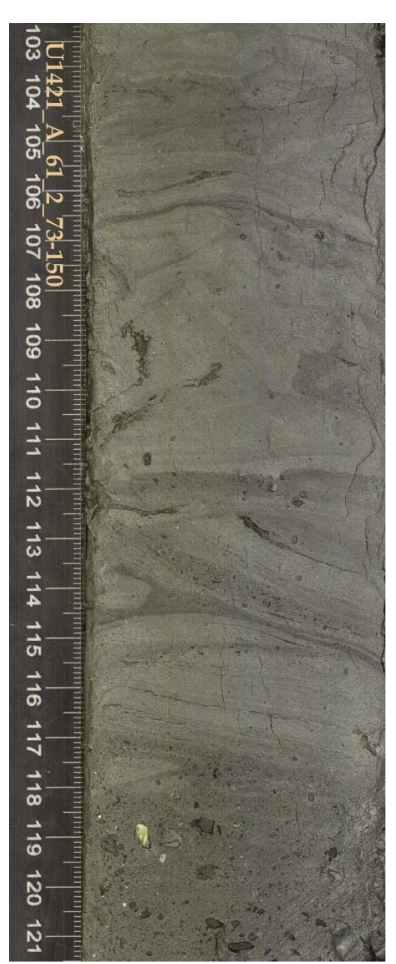


Figure F7. Examples of clasts, macrofossils, and bioturbation features, Site U1421. A. Sandstone clast with original internal bedding (arrows) preserved (interval 341-U1421A-8H-1, 132-137 cm). B. Siltstone clast with a pyrite-coated shell fragment (interval 341-U1421A-20X-1, 11-13 cm). C. Close-up of pyrite-coated shell fragment in B; length $=11 \mathrm{~mm}$ ). D. Porphyritic basalt clast with white phenocrysts (interval 341-U1421A-11H2, 45-47 cm). E. Diorite clast (interval 341-U1421A-39X-1, 14-17 cm). F. Gneiss clast (interval 341-U1421A$13 \mathrm{H}-2,65-69 \mathrm{~cm})$. G. Pyrite-bearing very coarse sandstone clast (interval 341-U1421A-34X-1, 61-66 cm). H. Rhyolite clast (interval 341-U1421A-43X-CC, 36-41 cm). I. Quartz-rich gneiss clast (interval 341-U1421A4H-1, 4-6 cm). J. Bioturbated mud (interval 341-U1421A-61X-1, 19-25 cm). K. Bivalve of the genus Cyclocardia sp. that has been bored by a naticid gastropod (interval 341-U1421C-1H-6, 43-43 cm. Scale bar is in millimeters.
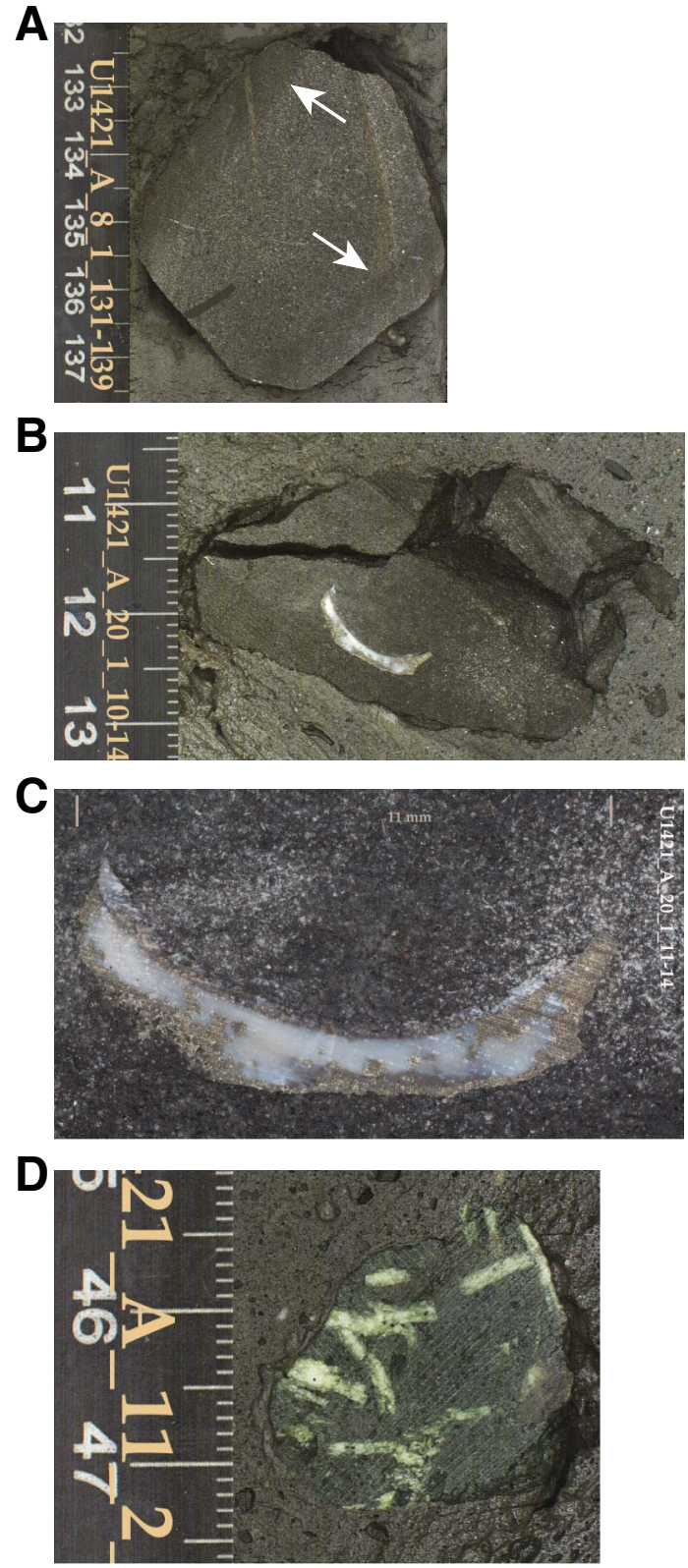
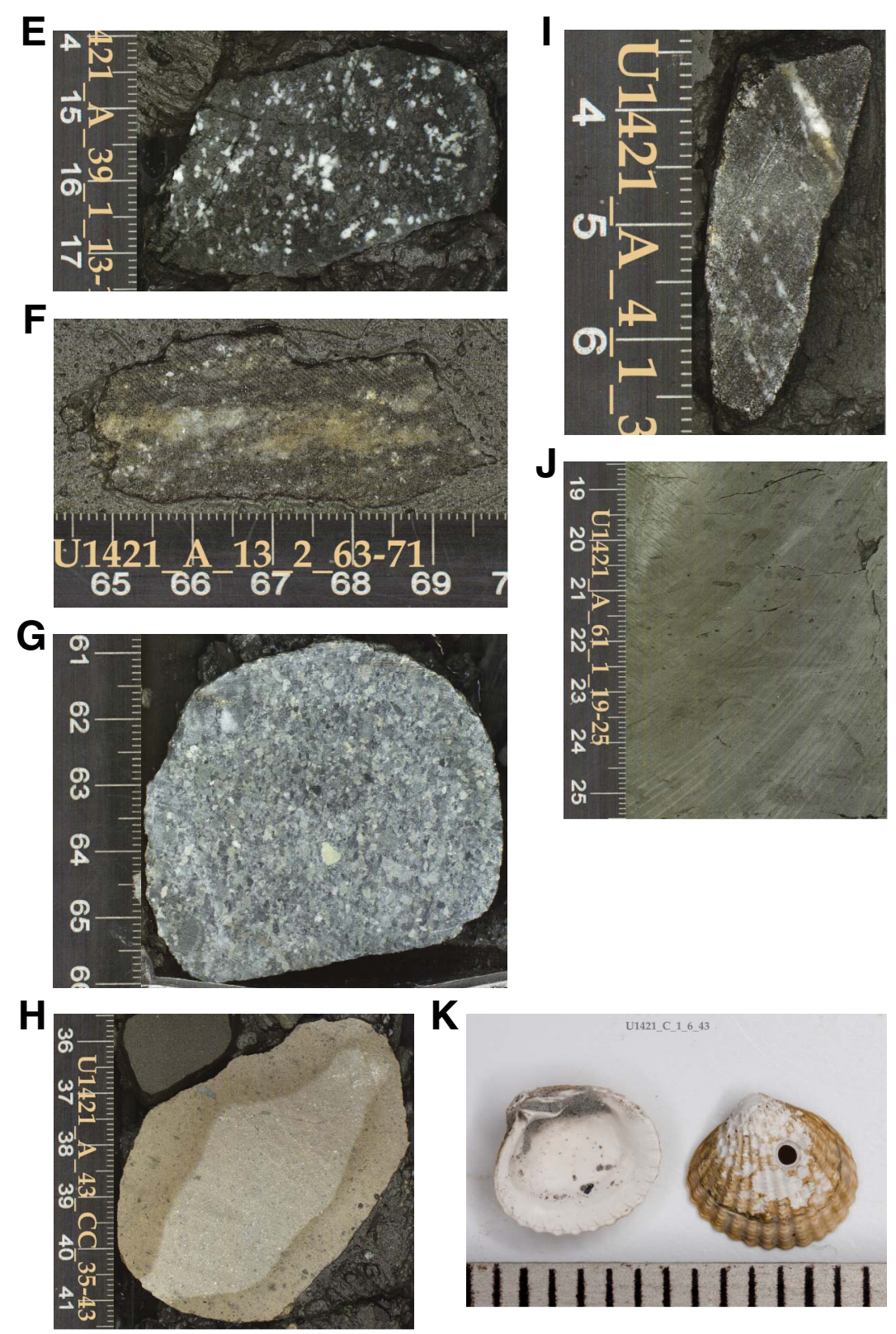
Figure F8. Gamma ray attenuation (GRA) bulk density data measured on the WRMSL (dots) vs. discrete wet bulk density data (circles), Hole U1421A. Sample lithologies: red/black = clast-rich diamict, light-green/orange $=$ clast-poor diamict, green/black = mud, green/red = diatomaceous, and blue/black = interbedded silt and mud.

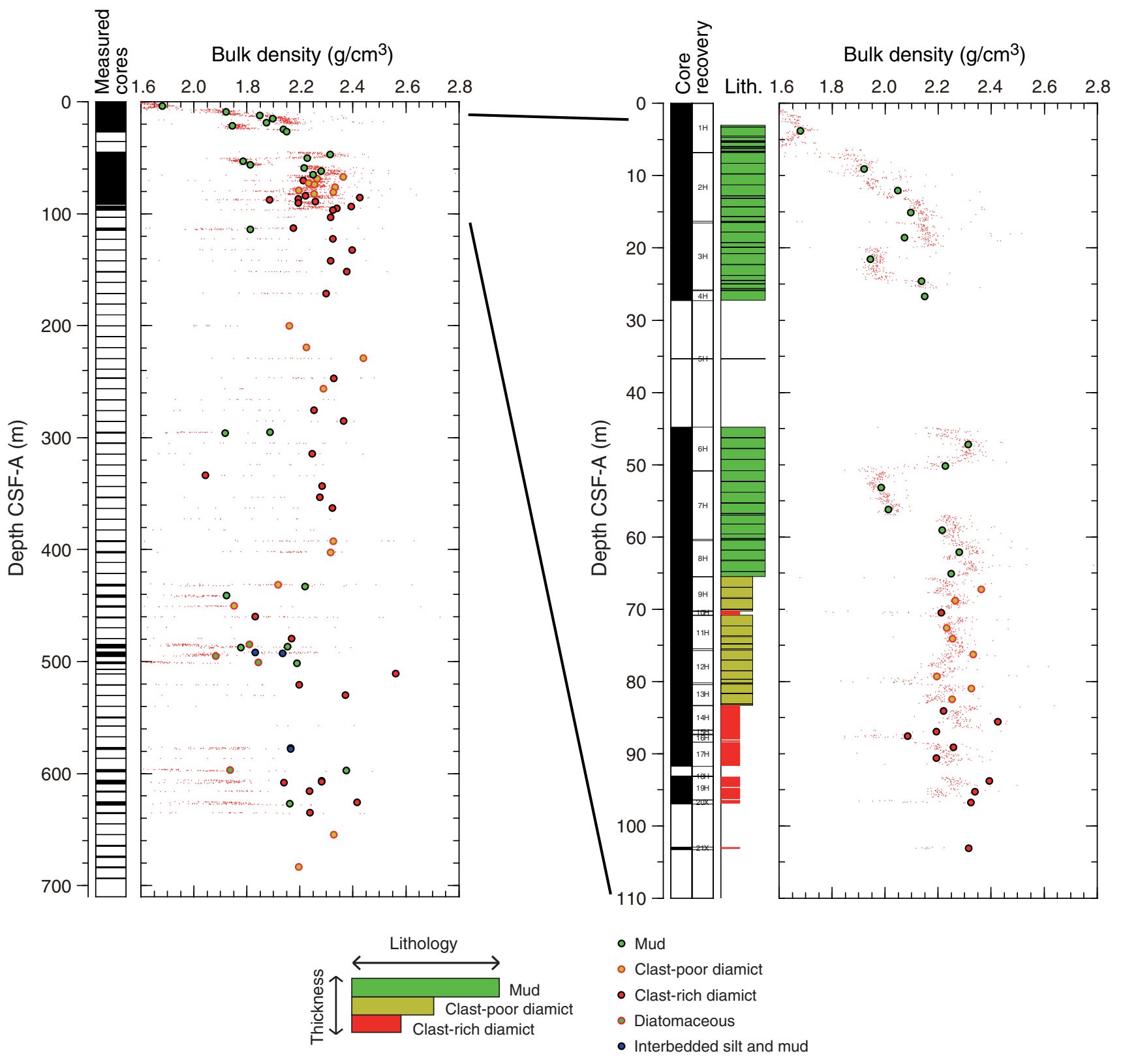


Figure F9. Ternary diagram showing average abundance of the main lithology types of clasts larger than $2 \mathrm{~mm}$ at Site U1421. $\mathrm{M}$ = metamorphic, $\mathrm{I}=$ igneous, $\mathrm{S}=$ sedimentary.

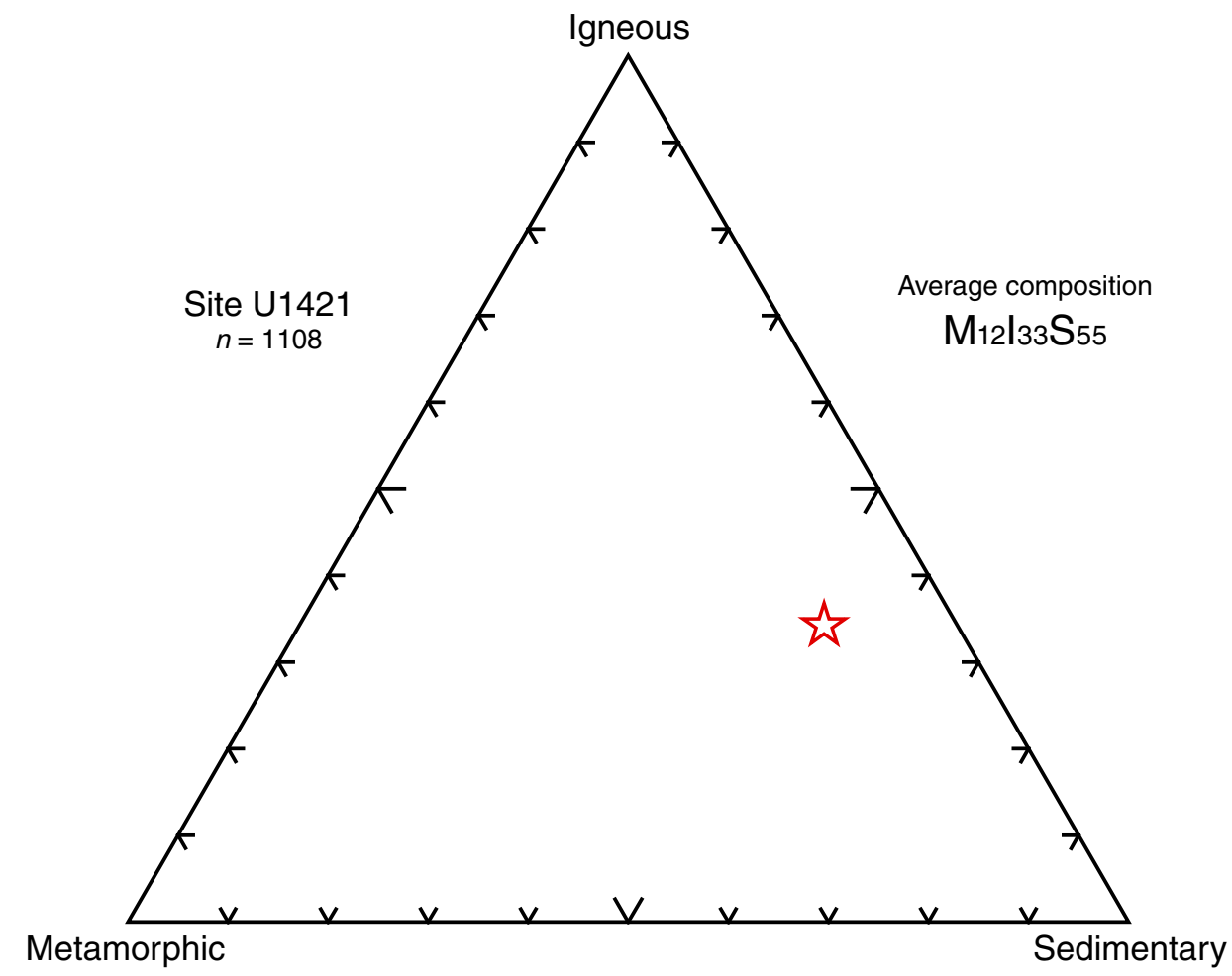


Figure F10. A. X-ray powder diffraction patterns, Hole U1421A. Bulk mineralogy is nearly constant downhole, although minor changes in intensity occur in various peaks. (Continued on next page.)

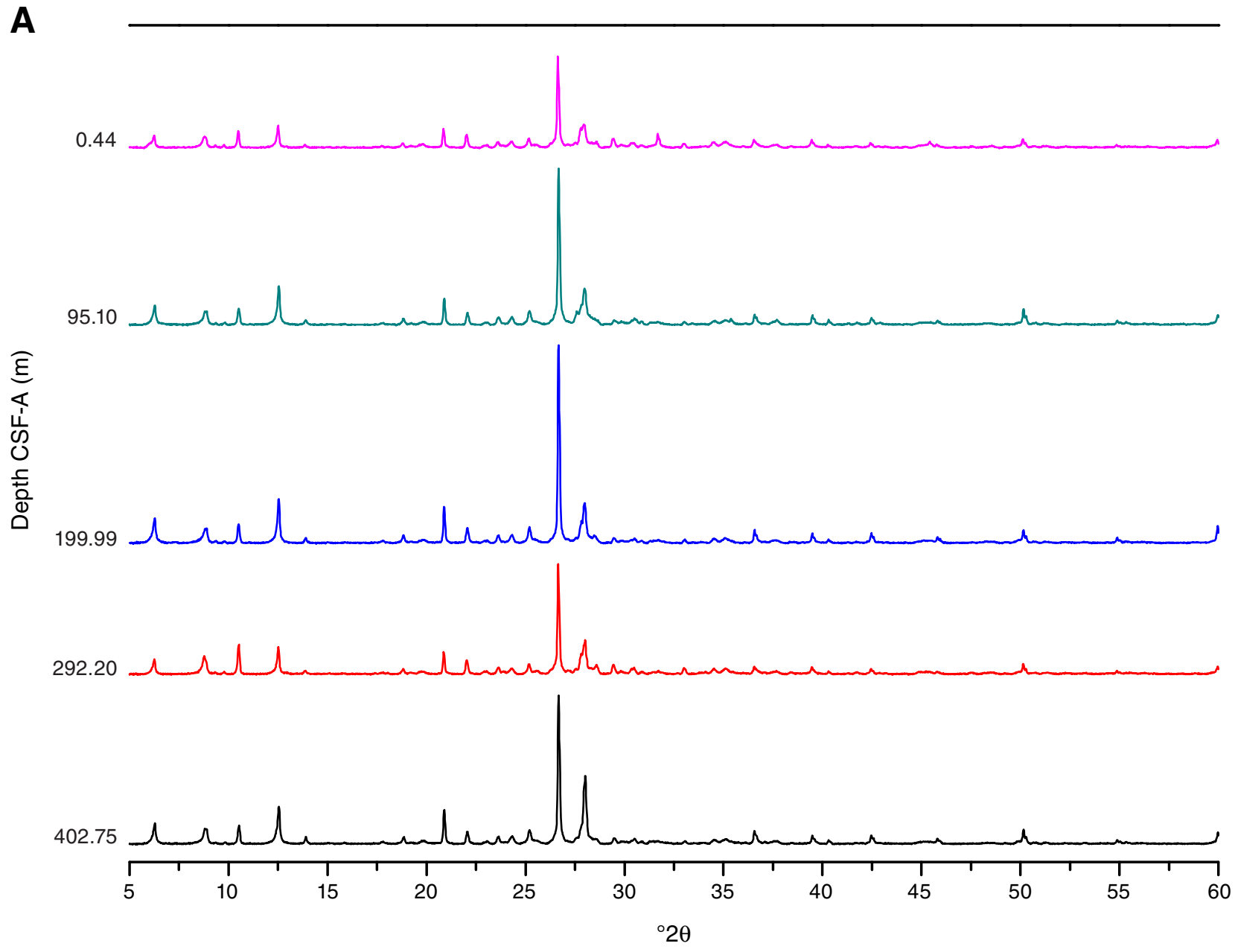


Figure F10 (continued). B. Comparative X-ray diffraction patterns from $4^{\circ}$ to $24^{\circ} 2 \theta$, Site U1421. Scans show downhole samples before (left) and after (right) glycolization treatment.
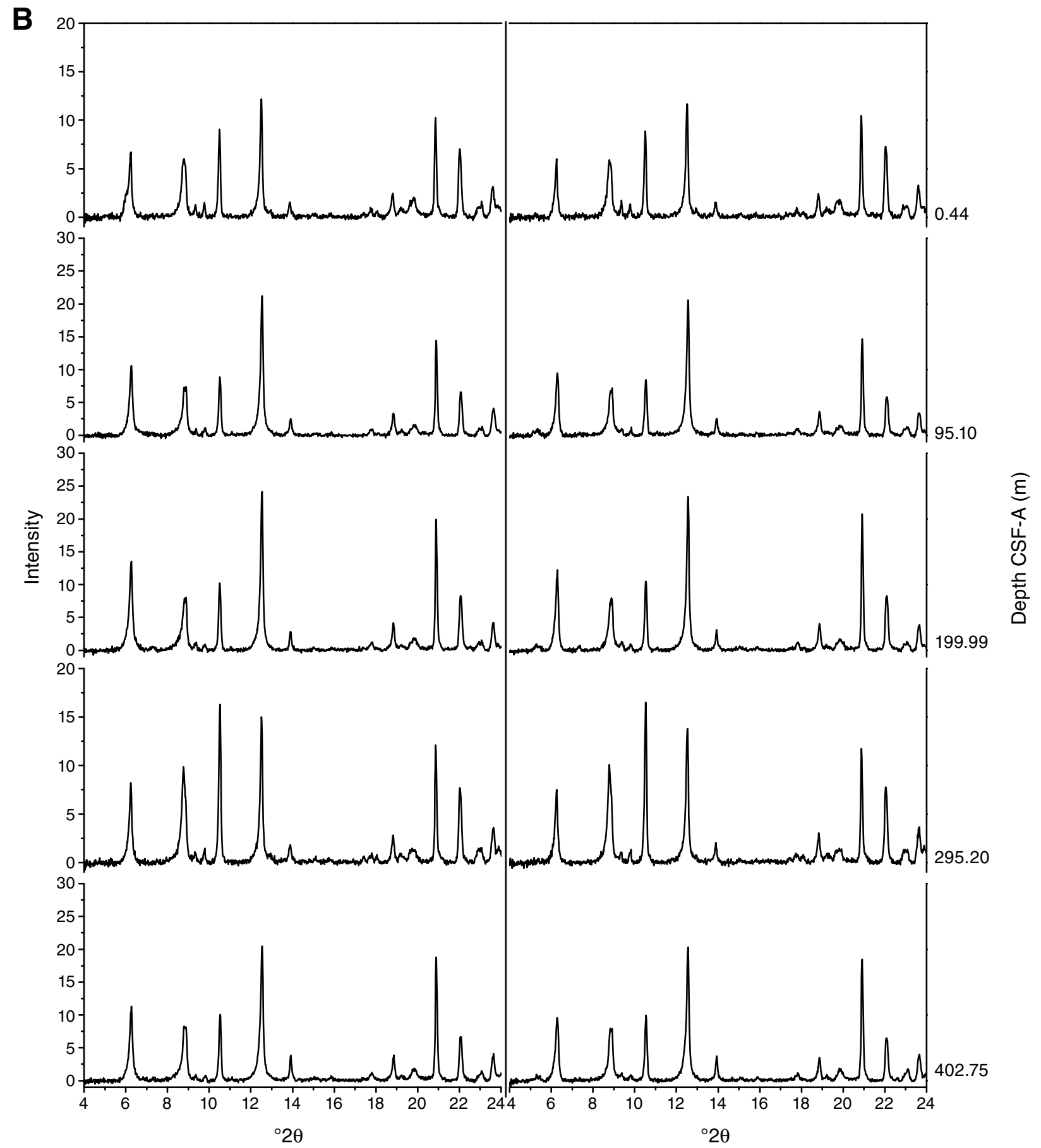
Figure F11. Schematic diagram of lithostratigraphic units and major lithologies, Site U1421. Circles = intervals of mud with high bioturbation. With the exception of core recovery, downcore profiles represent the occurrence of a described lithologic feature. Gray rectangles highlight depths where core recovery was $<10 \%$ and largely consists of washed pebbles, drilled rock, and clast-rich diamict. The low-recovery interval between 25 and 36 m CSF-A was partly recovered in Hole U1421C (see "Stratigraphic correlation") and largely consists of mud with abundant and common clasts.

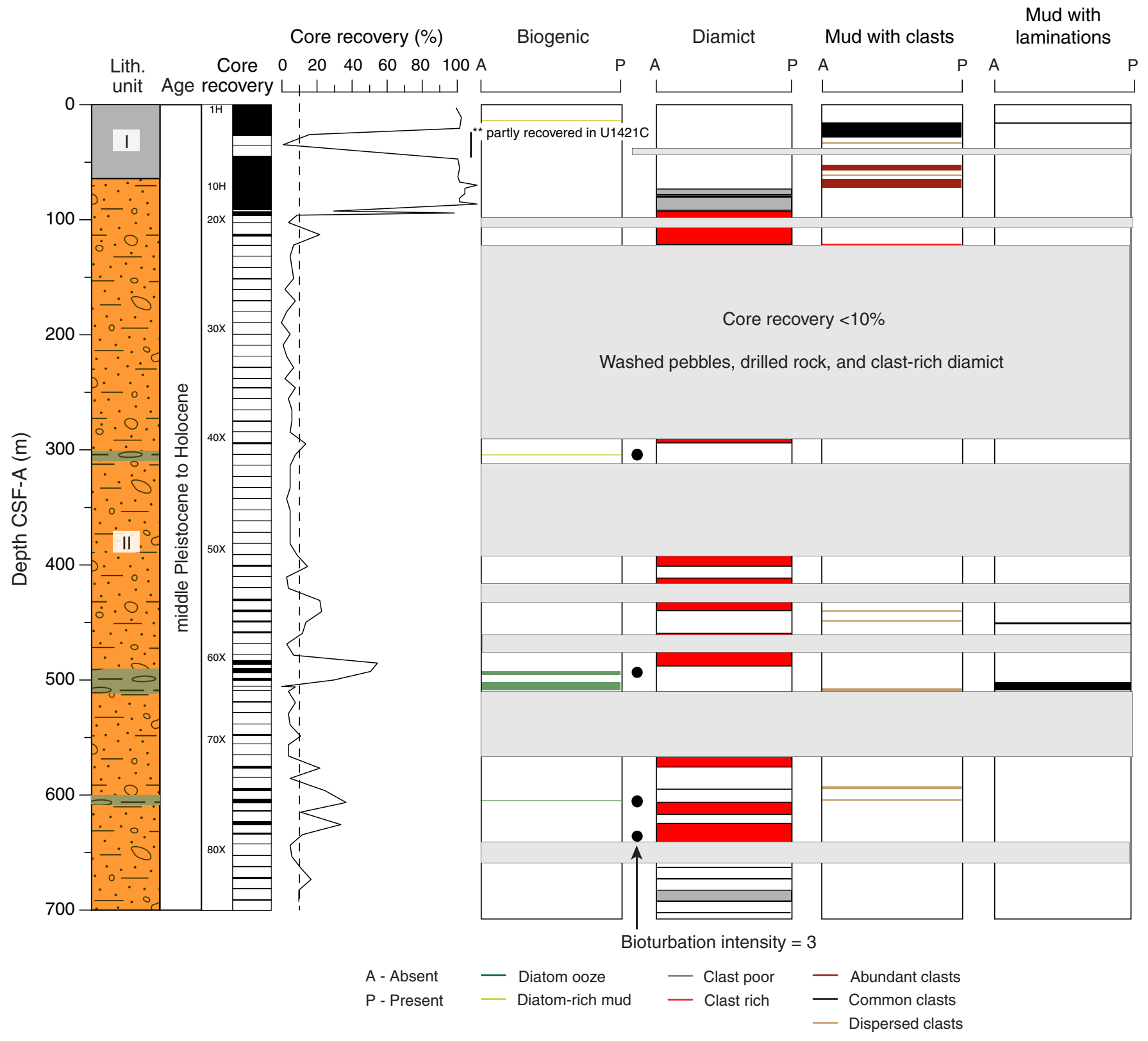


Figure F12. Physical properties measurements, Hole U1421A. WRMSL = Whole-Round Multisensor Logger, MS $=$ magnetic susceptibility. $\mathrm{MAD}=$ Moisture and density, GRA = Gamma ray attenuation. $\mathrm{NGR}=$ natural gamma radiation. A. 0-353 m CSF-A. (Continued on next page.)

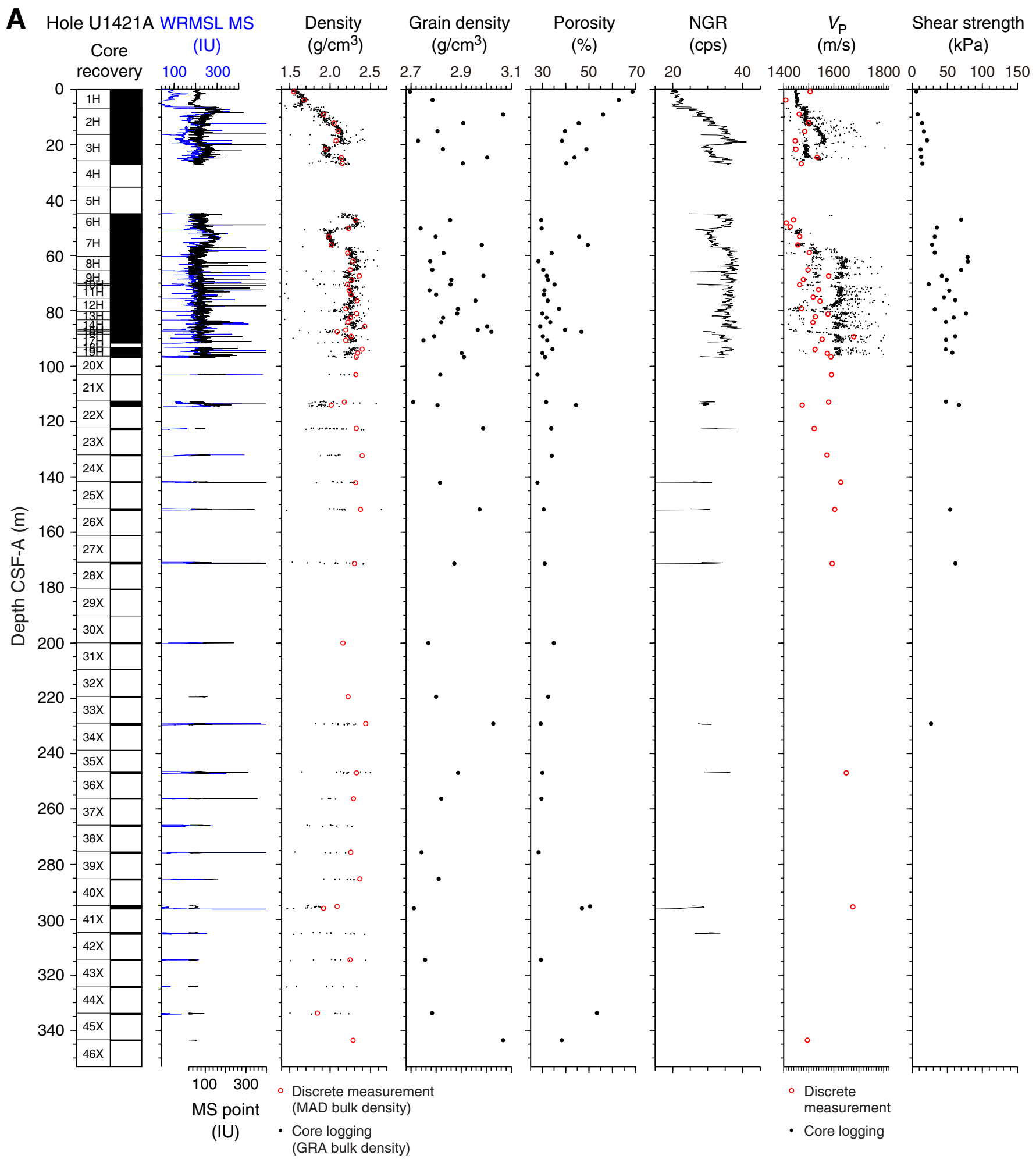


Figure F12 (continued). B. 353-703 m CSF-A.

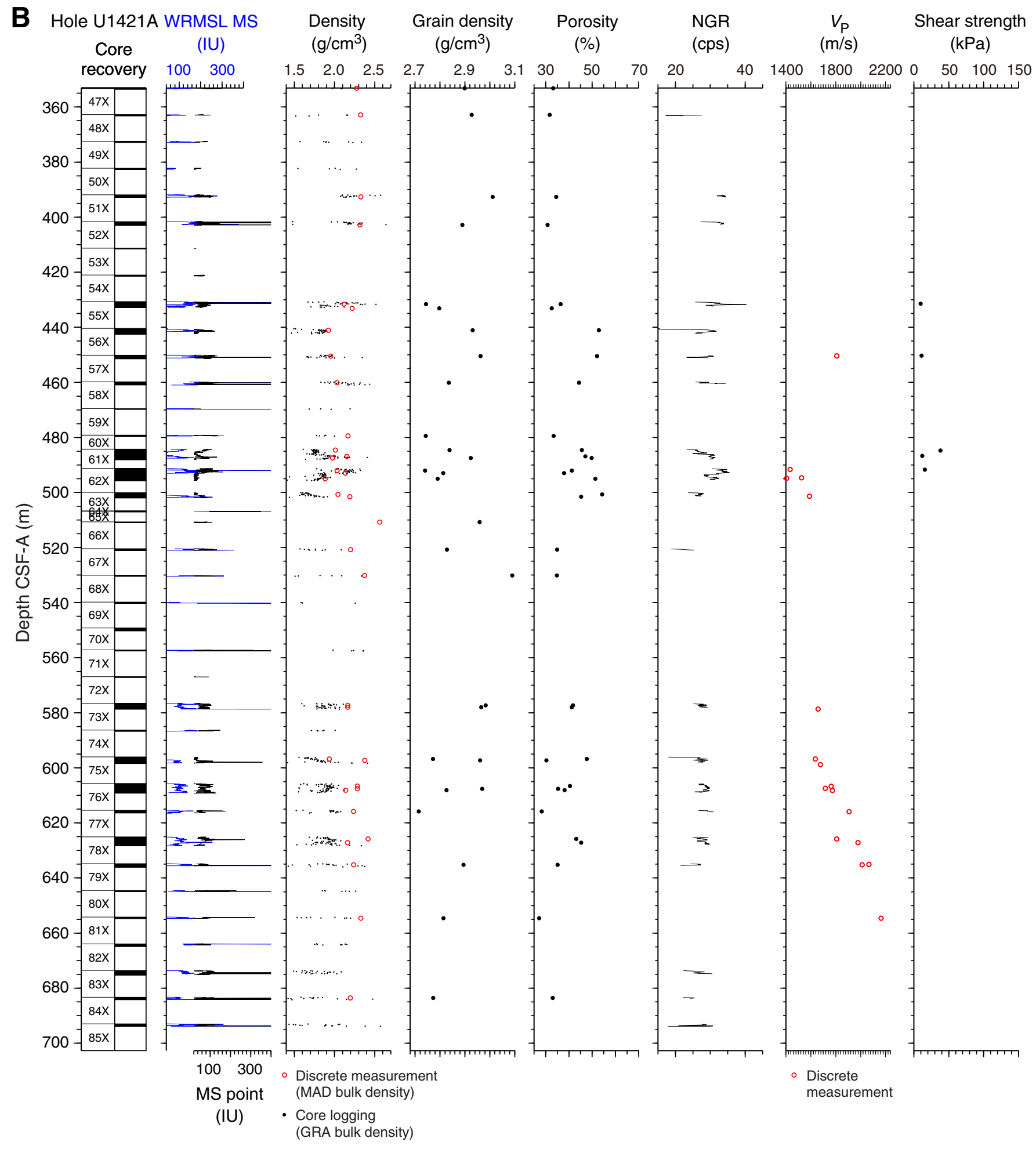


Figure F13. Abundance and preservation of diatoms, radiolarians, and planktonic and benthic foraminifers, Site U1421. Abundance: $\mathrm{D}=$ dominant, $\mathrm{A}=$ abundant, $\mathrm{C}=$ common, $\mathrm{F}=\mathrm{few}, \mathrm{R}=$ rare, $\mathrm{P}=$ present $\mathrm{B}=\mathrm{barren}$. Preservation: $\mathrm{VG}=$ very good, $\mathrm{G}=$ good, $\mathrm{M}=$ moderate, $\mathrm{P}=$ poor.

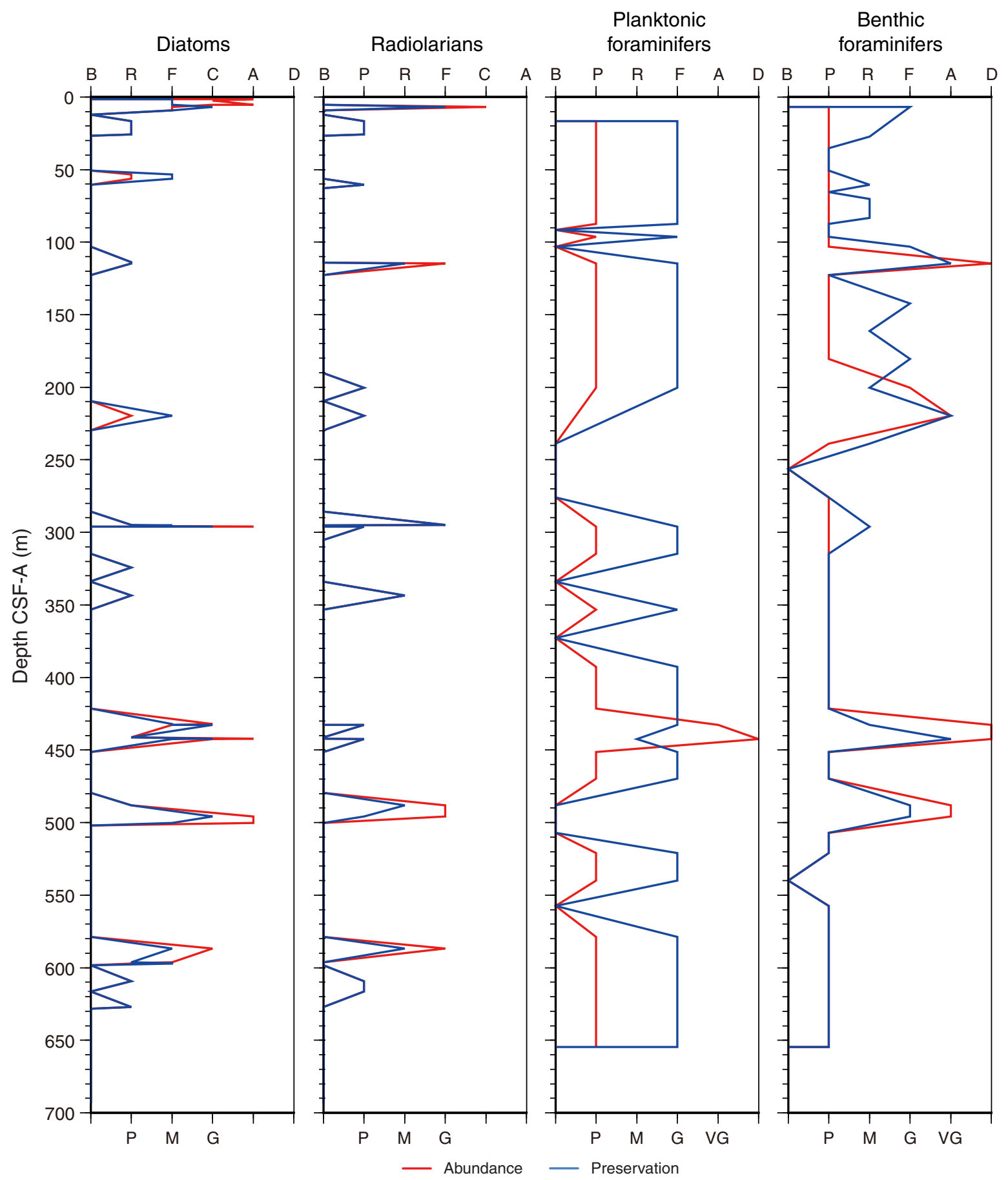


Figure F14. Rank abundance of paleoenvironmental indicators, Site U1421. Benthic foraminifers: Epistominella pacifica, Elphidium spp., and Eubuliminella exilis. Diatoms: Chaetoceros resting spores, neritic/coastal species, and sea ice-related species. Radiolarians: neritic species and bathyal species. Planktonic foraminifer: Neogloboquadrina pachyderma. Abundance: $\mathrm{D}=$ dominant, $\mathrm{A}=$ abundant, $\mathrm{C}=\mathrm{common}, \mathrm{F}=\mathrm{few}, \mathrm{R}=\mathrm{rare}, \mathrm{P}=$ present, $\mathrm{X}=$ present.

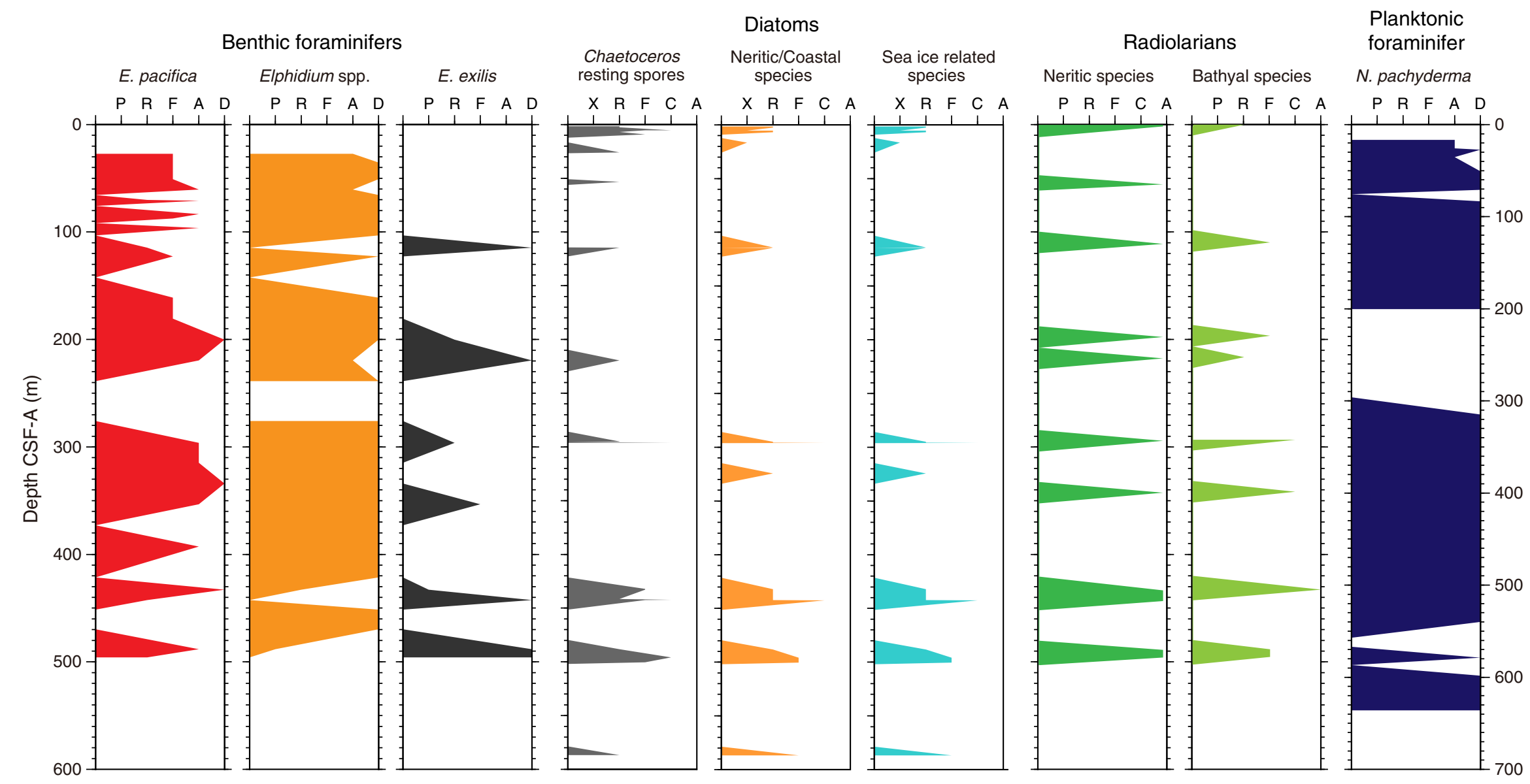


Figure F15. Magnetic susceptibility data for the interval of the continuous splice in Holes U1421A-U1421C and the splice record, 0-30 m CCSF-A. Gray boxes = intervals used to construct the splice, dashed vertical lines with question marks = append points that should be treated with caution (see text for details). Asterisks = intervals in which magnetic susceptibility data could not be run on the WRMSL because of core-liner patches; in these cases, magnetic susceptibility is available from STMSL or SHMSL runs.

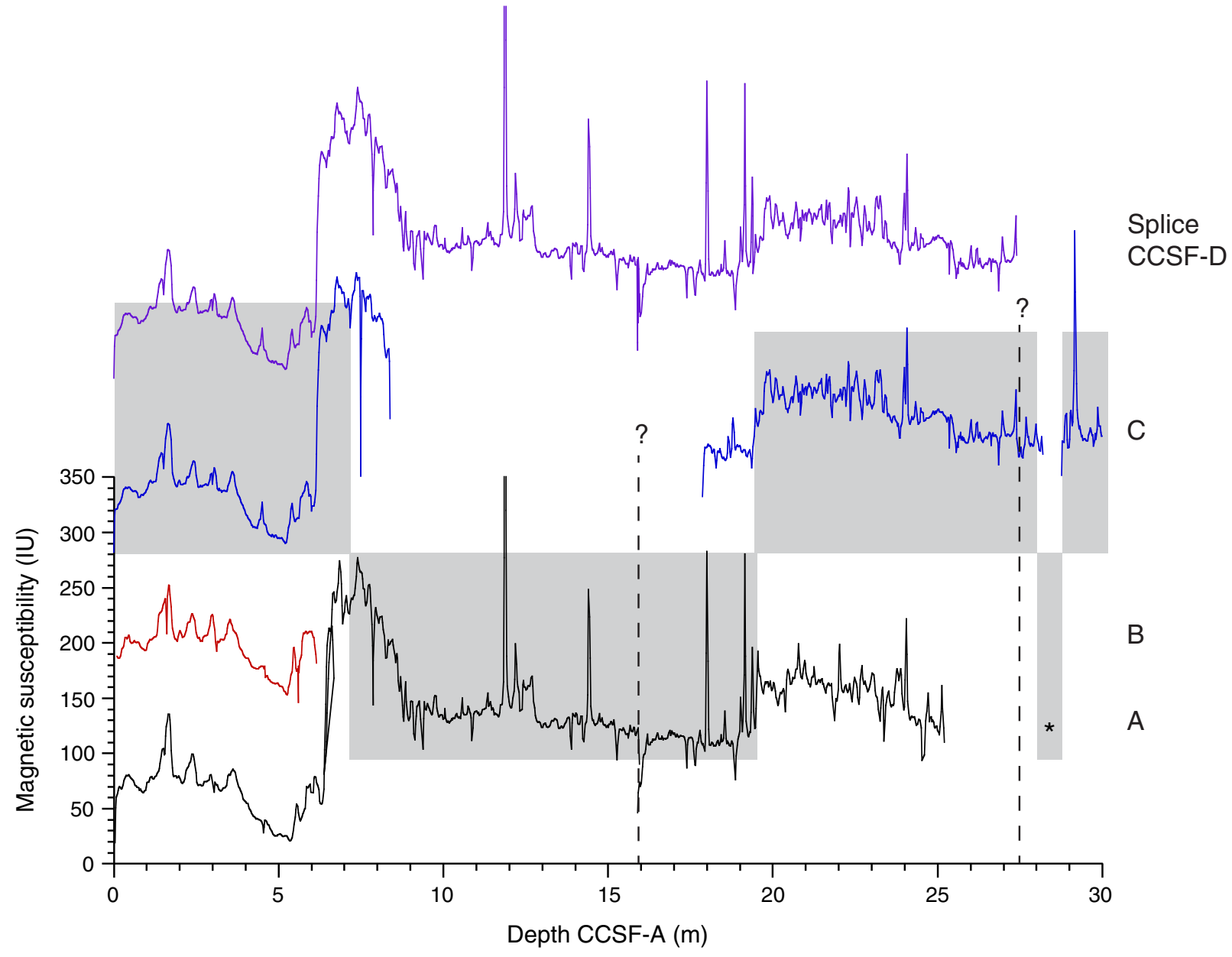


Figure F16. GRA bulk density data for the interval of the continuous splice in Holes U1421A-U1421C and the splice record, 0-30 m CCSF-A. Gray boxes = intervals used to construct the splice, dashed vertical lines with question marks = append points that should be treated with caution (see text for details). Asterisks = intervals in which magnetic susceptibility data could not be run on the WRMSL because of core-liner patches; in these cases, magnetic susceptibility is available from STMSL or SHMSL runs.




Figure F17. Dissolved chemical concentrations and headspace gas, Hole U1421A. A. Alkalinity. B. pH. C. Sulfate. D. Ammonium. E. Bromide. F. Methane. G. Ethane. H. Silica. I. Salinity. J. Chloride. K. Sodium. Full details of Lithology column are shown in Figure F11 (see "Lithostratigraphy").

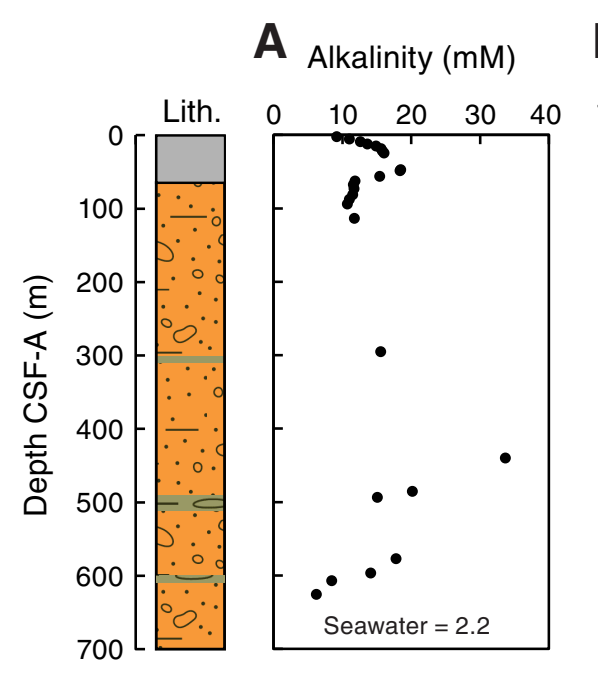

B

C Sulfate (mM)

$\mathbf{D}_{\text {Ammonium (mM) }}$

E Bromide (mM)
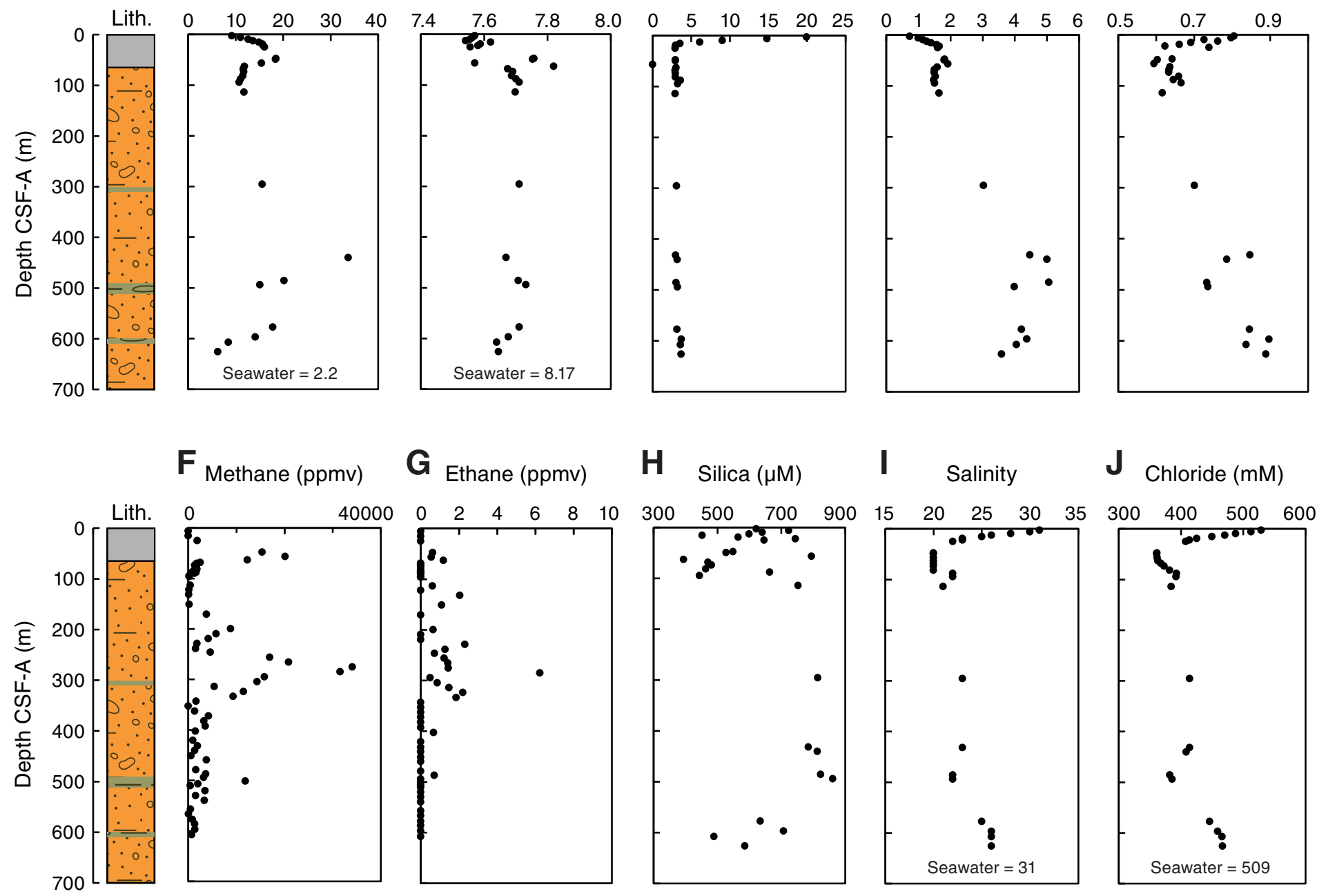

\section{$\mathbf{G}_{\text {Ethane (ppmv) }}$}

H Silica $(\mu \mathrm{M})$

I Salinity

J Chloride (mM)

K Sodium (mM)
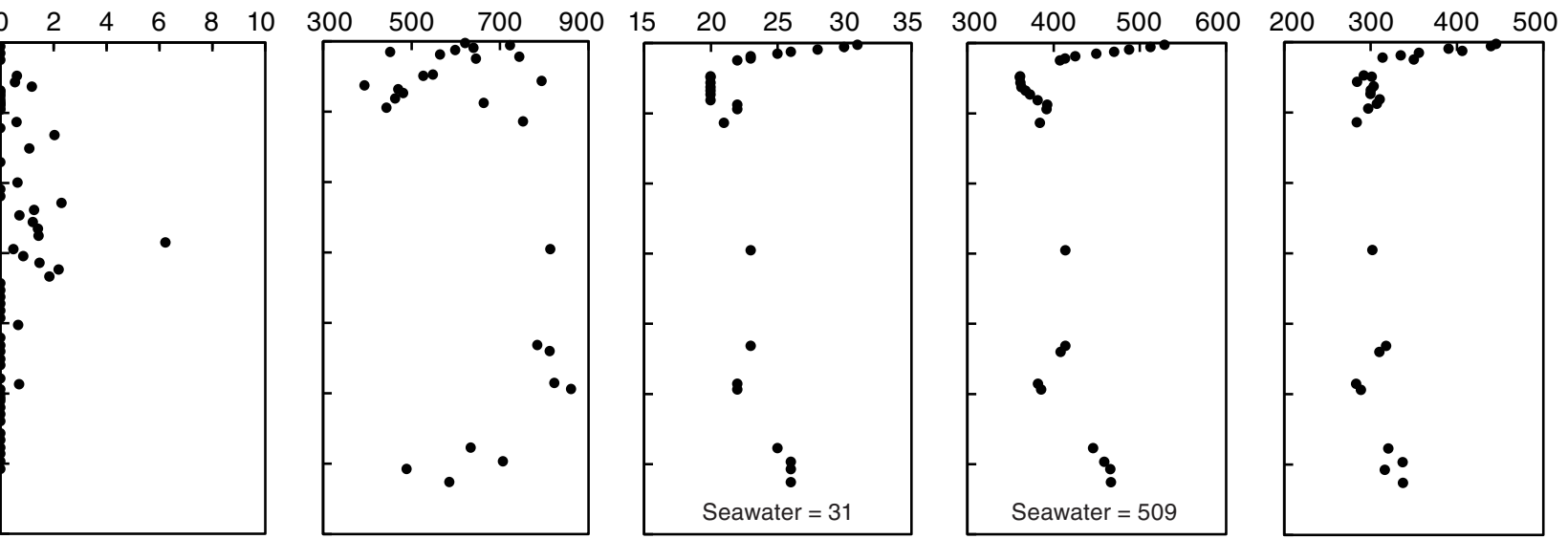
Figure F18. Dissolved chemical concentrations, Hole U1421A. A. Calcium. B. Potassium. C. Magnesium. D. Lithium. E. Boron. F. Barium. G. Strontium. H. Iron. I. Manganese. J. Phosphate. Full details of Lithology column are shown in Figure F11 (see "Lithostratigraphy").

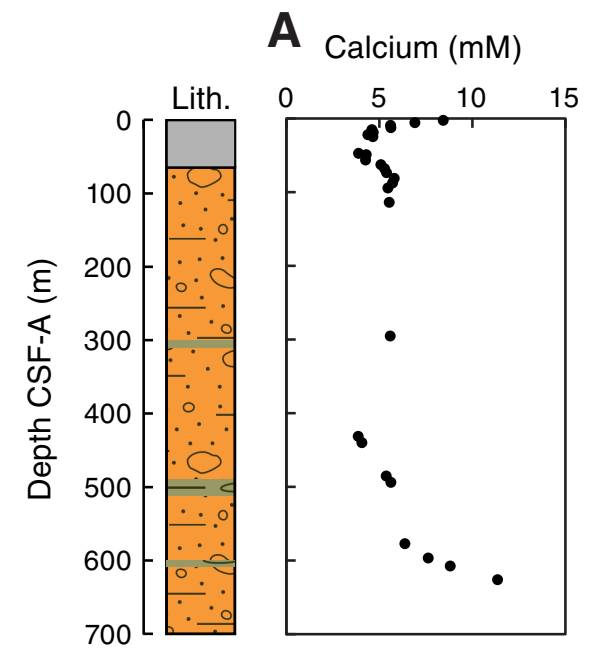

$$
\text { B Potassium (mM) } \quad \mathbf{C}_{\text {Magnesium (mM) }}
$$

D Lithium $(\mu \mathrm{M})$

E Boron $(\mu \mathrm{M})$
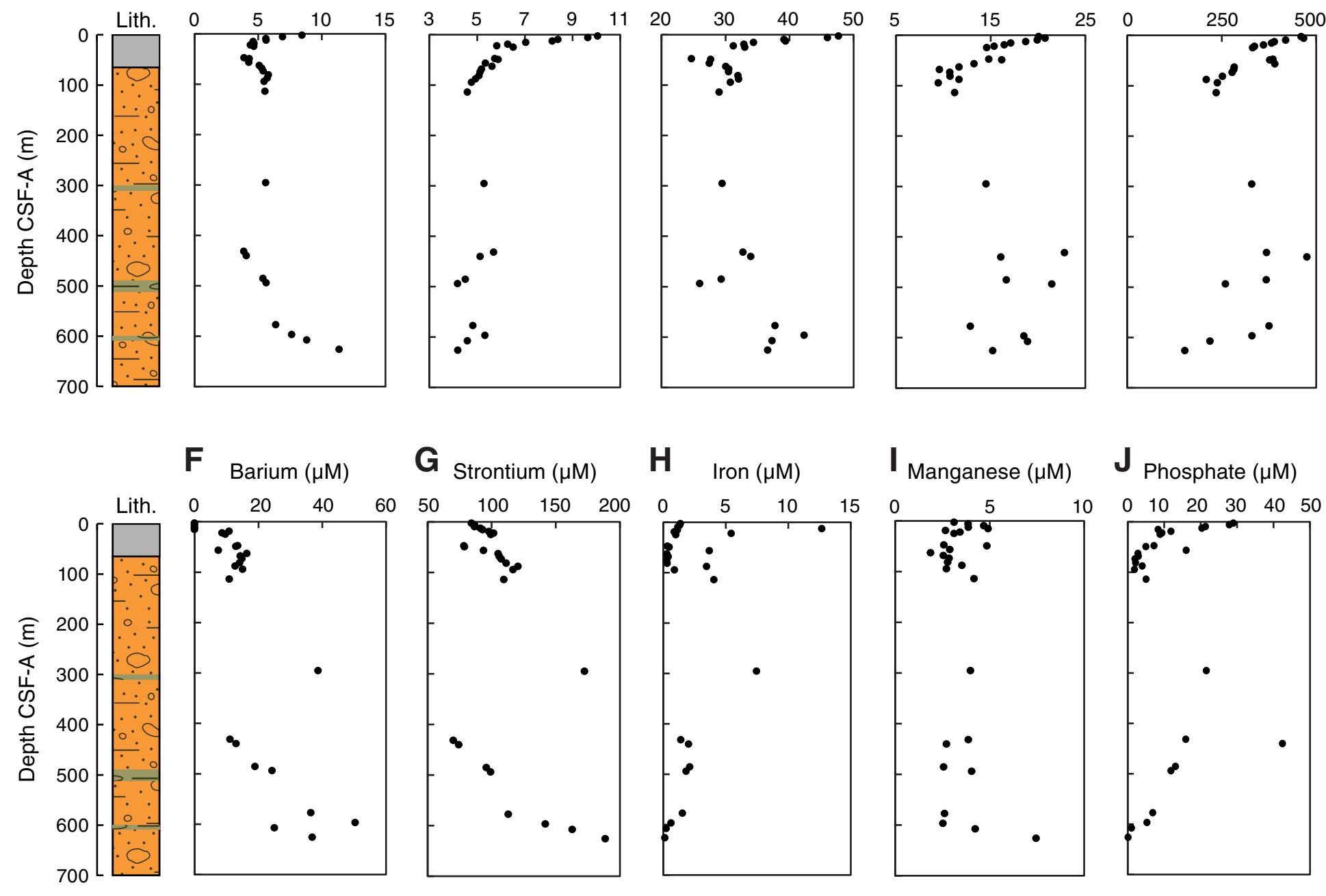

G Strontium $(\mu \mathrm{M})$

H Iron $(\mu \mathrm{M})$

I Manganese $(\mu \mathrm{M})$

J Phosphate $(\mu \mathrm{M})$
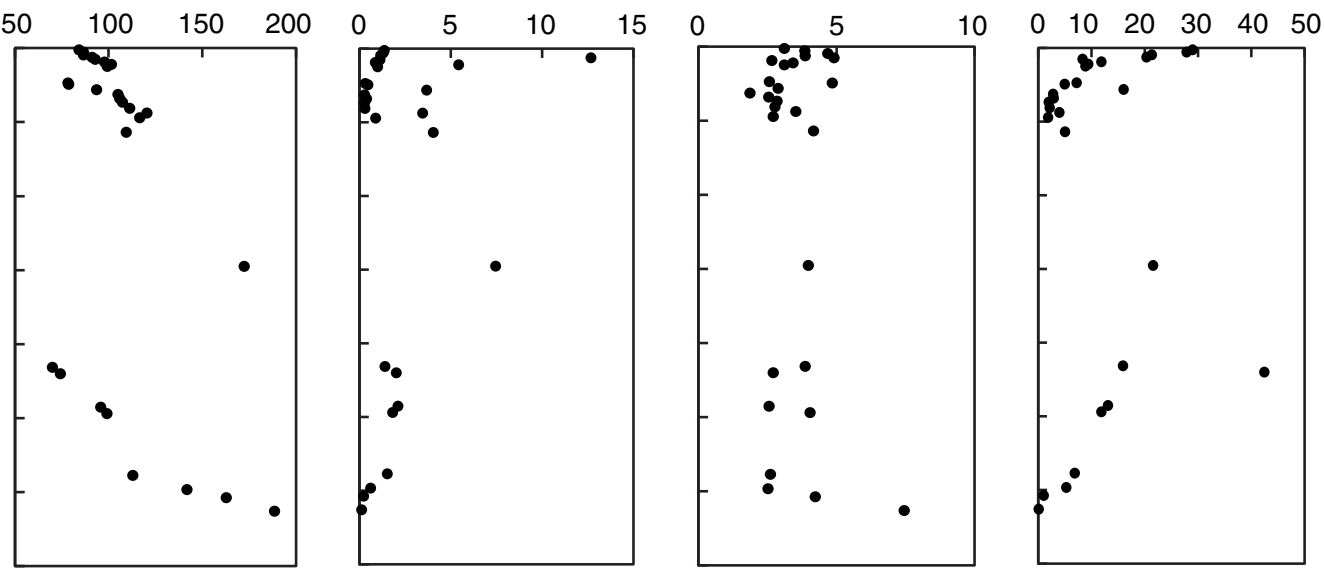
Figure F19. Solid-phase chemical parameters, Hole U1421A. A. Total organic carbon (TOC). B. Total nitrogen (TN). C. TOC/TN ratio (C/N). D. $\mathrm{CaCO}_{3}$. E. Scatter plot of TOC vs. TN. Full details of Lithology column are shown in Figure F11 (see "Lithostratigraphy").
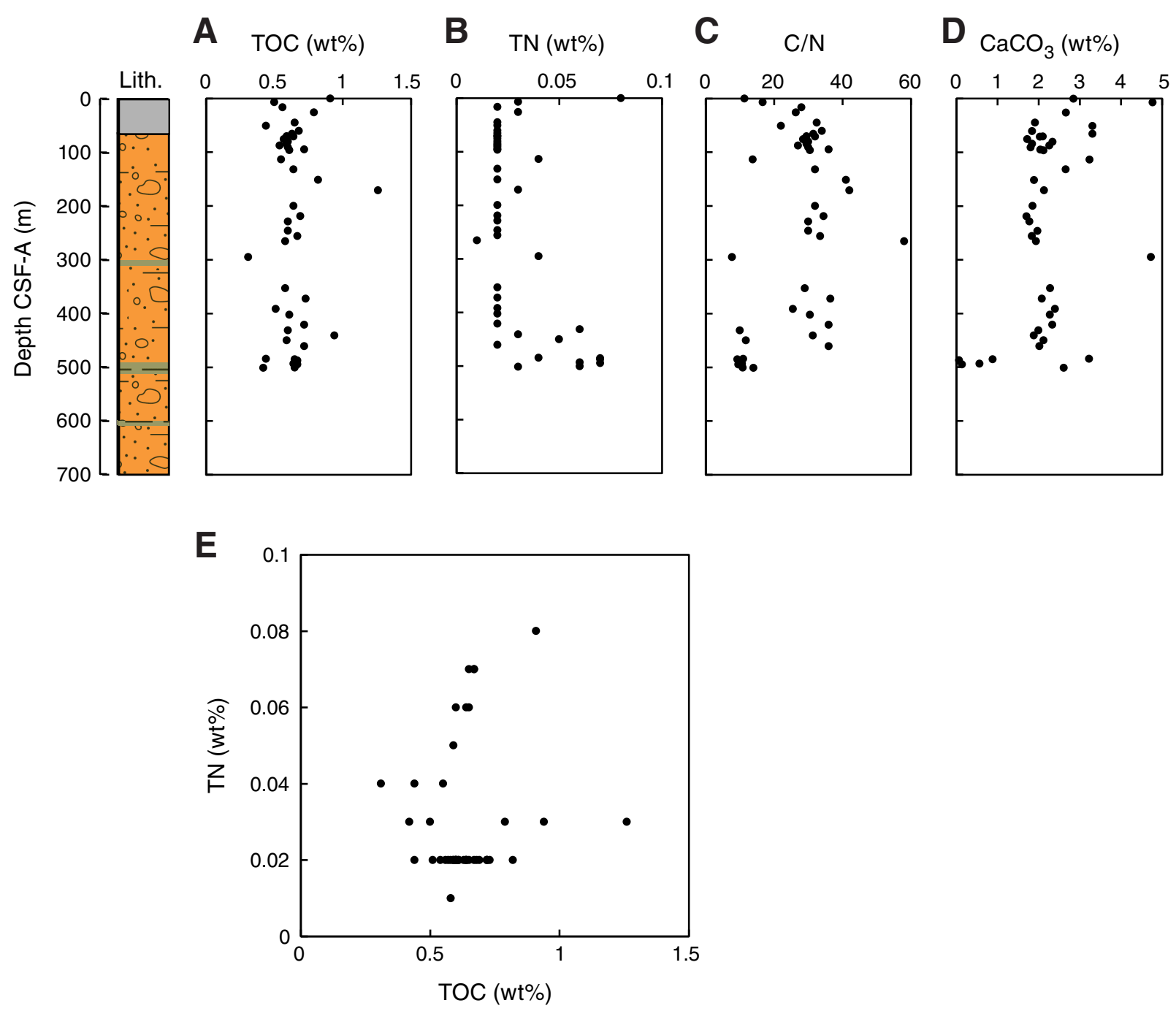
Figure F20. Depth profiles of the chlorinity-normalized and original concentrations for selected pore water constituents, Hole U1421A. A. Sulfate. B. Alkalinity. C. Calcium. D. Magnesium. E. Bromide.

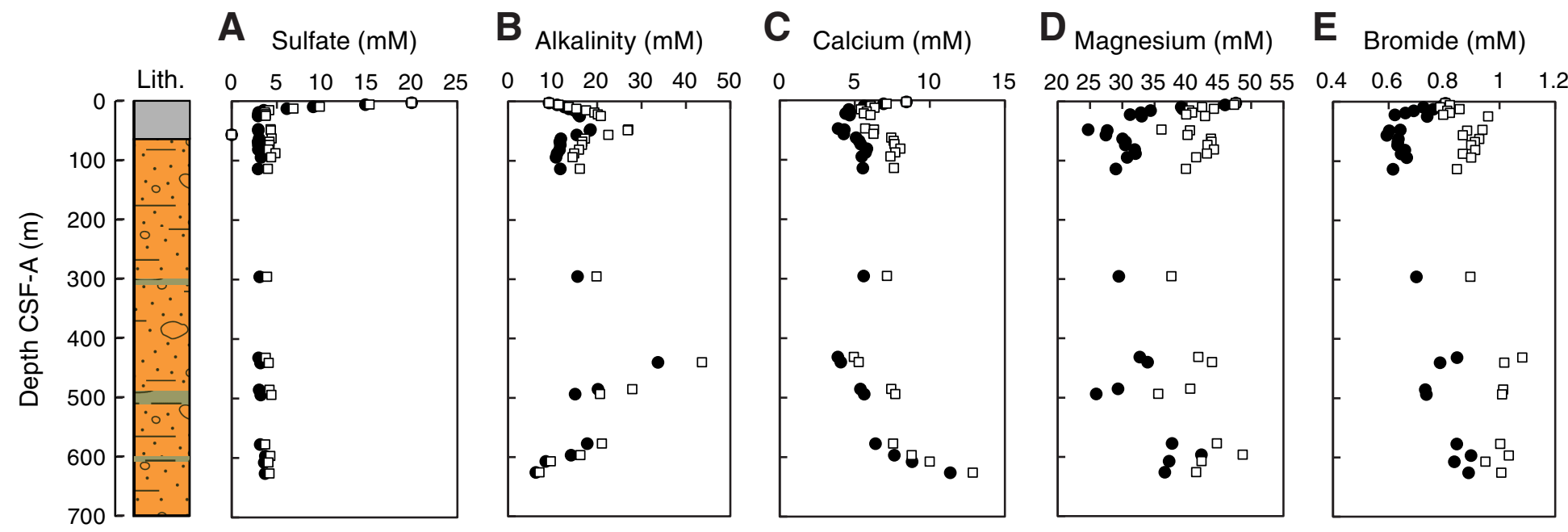

- Original 口 Chlorinity-normalized 
Figure F21. Physical properties measurements, Hole U1421C. WRMSL = Whole-Round Multisensor Logger, MS $=$ magnetic susceptibility. GRA = gamma ray attenuation. NGR = natural gamma radiation .

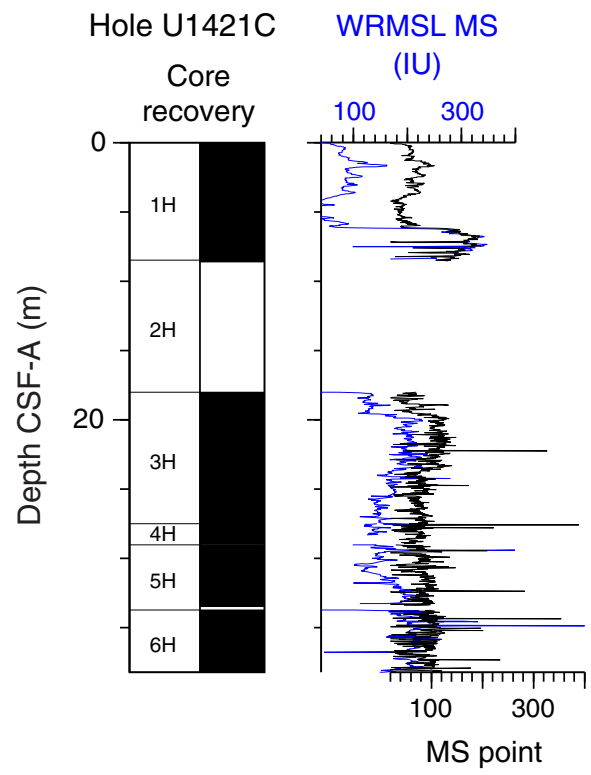

(IU)

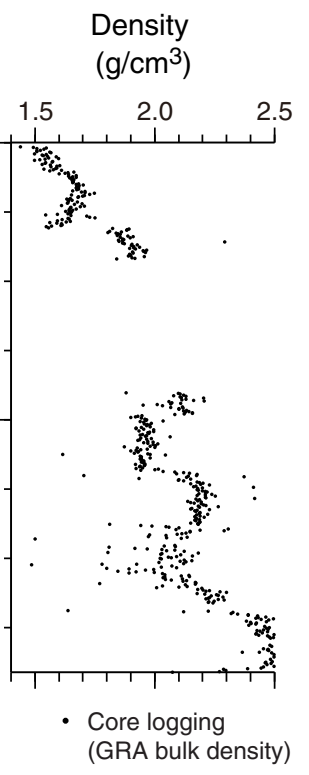

NGR

(cps)

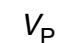

$(\mathrm{m} / \mathrm{s})$
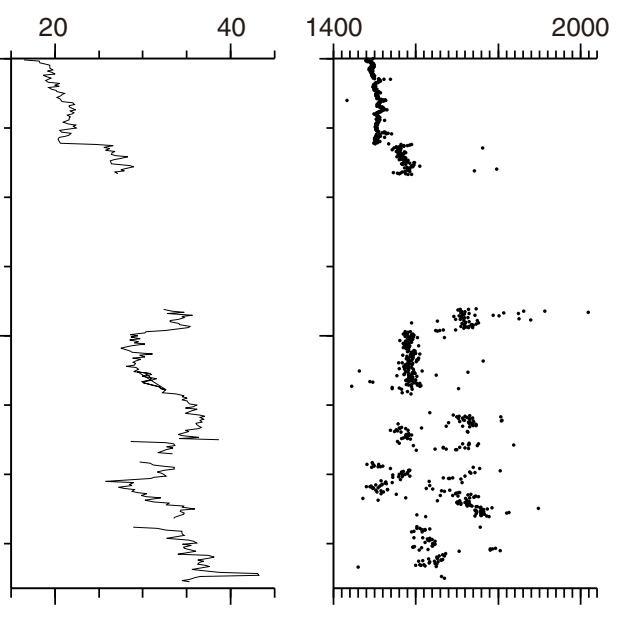

- Core logging 
Figure F22. Point-source magnetic susceptibility (MS) data from the APC portions of Holes U1421A-U1421C compared to Whole-Round Multisensor Logger (WRMSL) loop MS data from equivalent depths in those cores.

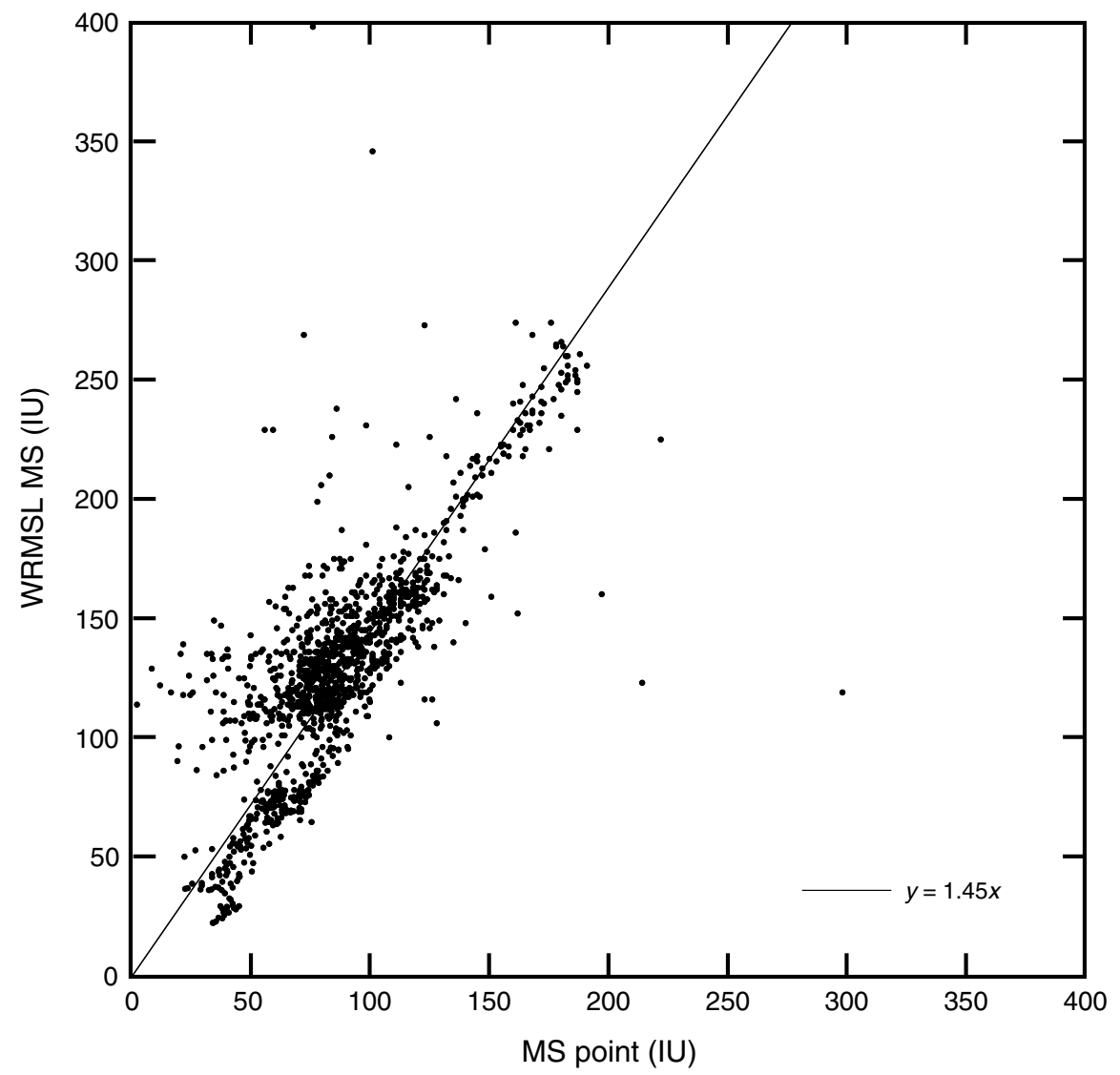


Figure F23. Whole-Round Multisensor Logger (WRMSL) gamma ray attenuation (GRA) bulk density compared to WRMSL magnetic susceptibility (MS) data, Site U1421 shown after Gaussian smoothing both data sets with a $10 \mathrm{~cm}$ window $( \pm 3 \sigma)$ and interpolation to constant resolution at $2.5 \mathrm{~cm}$. WRMSL MS ( $\kappa$; black) is also shown corrected for variability in recovered sediment volume by normalizing to WRMSL GRA bulk density, generating mass MS ( $\chi$; blue). Data in the shallowest $32 \mathrm{~m}$ CCSF-A reflect the stratigraphic composite splice (see "Stratigraphic correlation"); data from the deeper APC-acquired cores and from the extended core barrel portions of Hole U1421A are appended to form a single stratigraphic section.

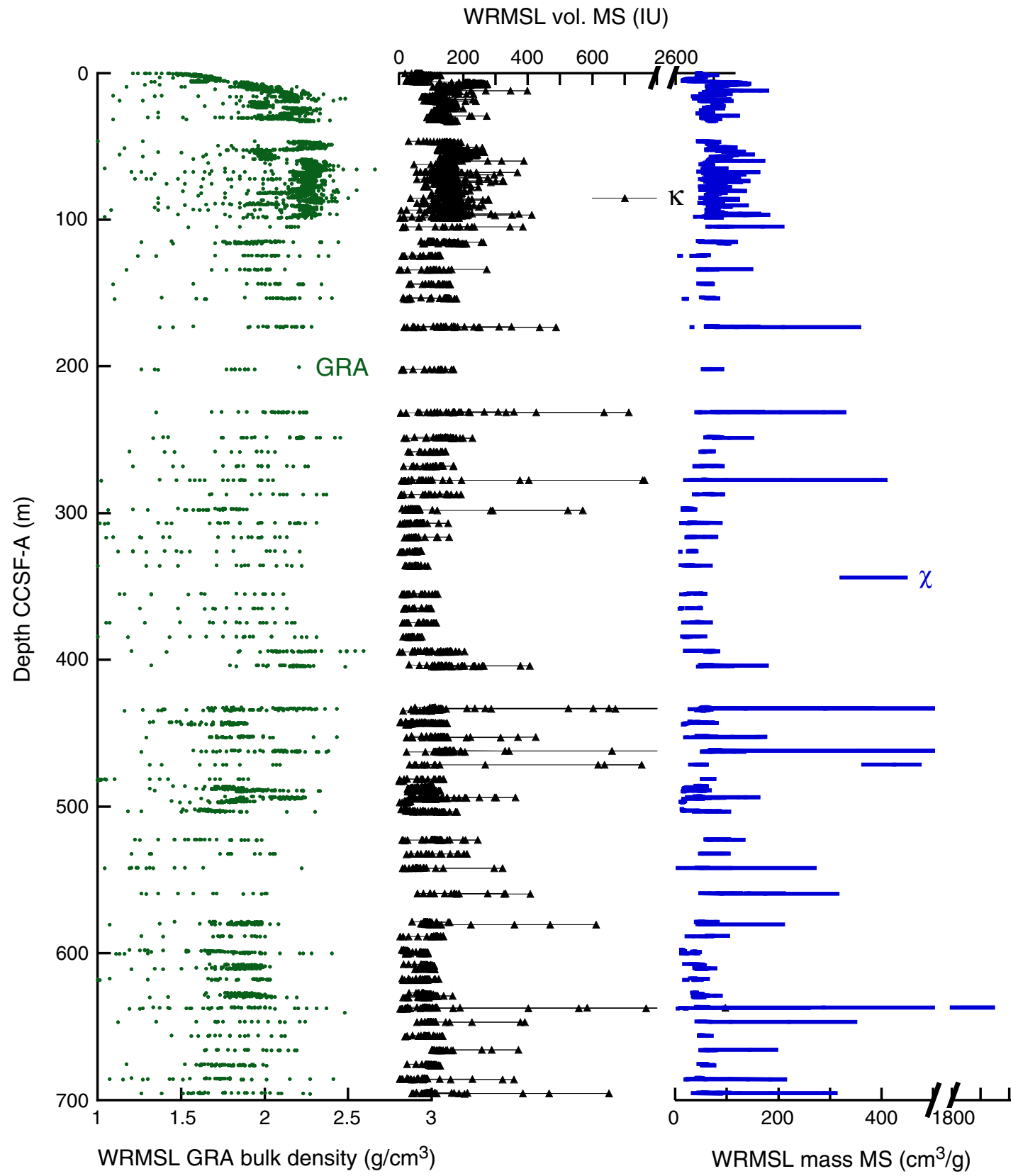


Figure F24. Scatter plot showing relationship between Whole-Round Multisensor Logger (WRMSL) $P$-wave logger measurements and discrete $P$-wave caliper (PWC) measurements.

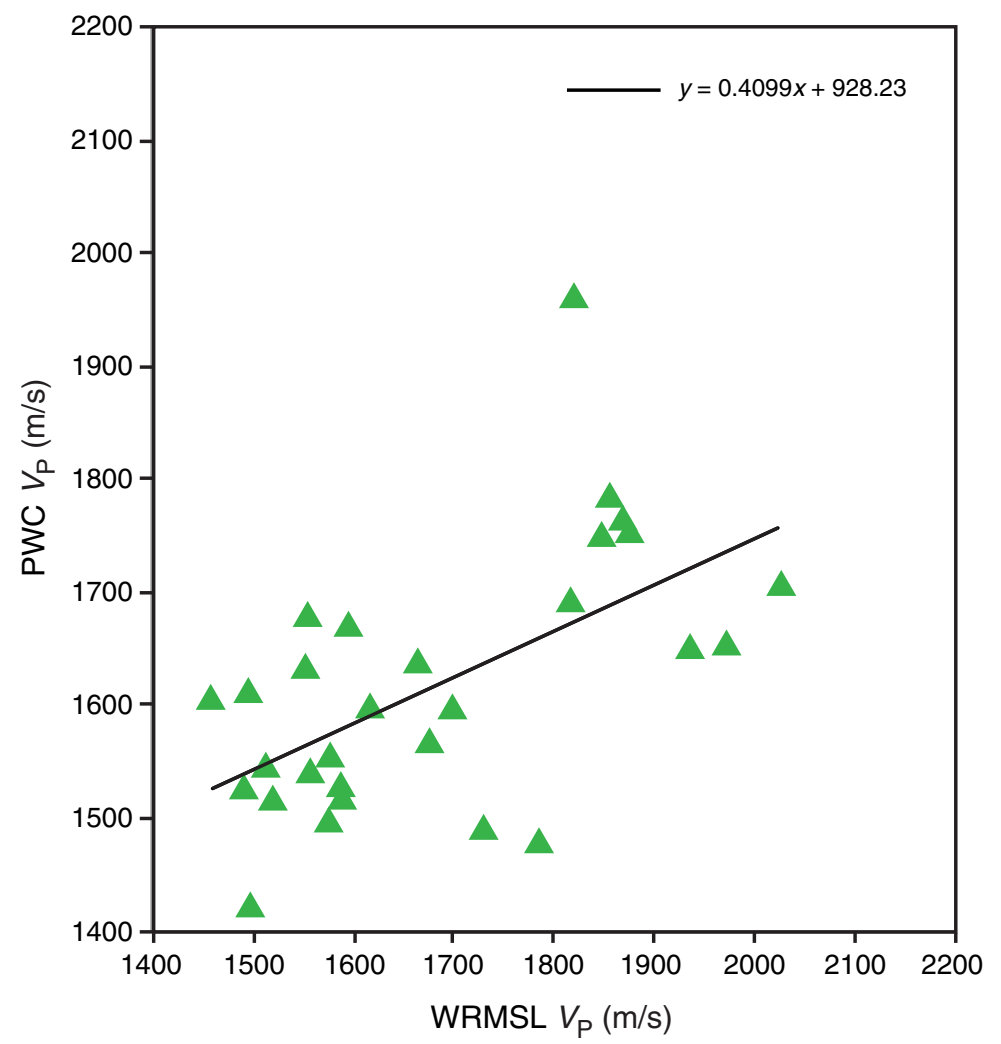


Figure F25. Whole-Round Multisensor Logger (WRMSL) gamma ray attenuation (GRA) bulk density compared to natural gamma radiation (NGR) data from Site U1421, shown after Gaussian smoothing both data sets with a $50 \mathrm{~cm}$ window $( \pm 3 \sigma)$ and interpolation to constant resolution at $10 \mathrm{~cm}$. NGR is also shown corrected for variability in recovered sediment volume by normalizing to WRMSL GRA bulk density. Data in the shallowest 32 m CCSF-A reflect the stratigraphic composite splice (see "Stratigraphic correlation"); data from the deeper APC and XCB portions of Hole U1421A are appended to form a single stratigraphic section.

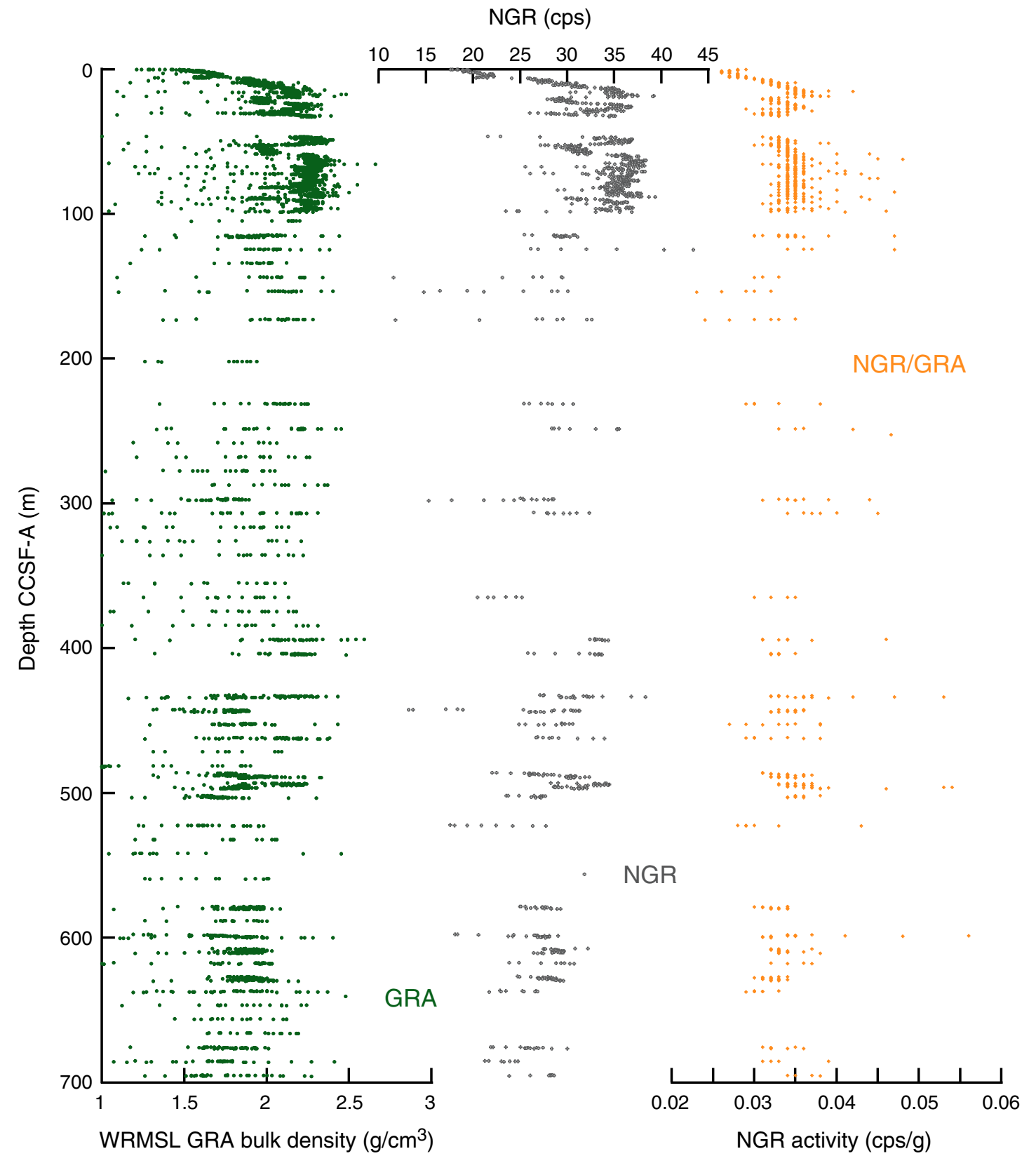


Figure F26. Bulk density, grain density, porosity, and void ratio measured using the moisture and density method, Hole U1421A. Sample lithologies: $\mathrm{red} / \mathrm{black}=$ clast-rich diamict, light-green/orange $=$ clast-poor diamict, green/black $=$ mud, green $/$ red $=$ diatomaceous, and blue $/$ black $=$ interbedded silt and mud. For more on major lithologies, see "Lithostratigraphy."
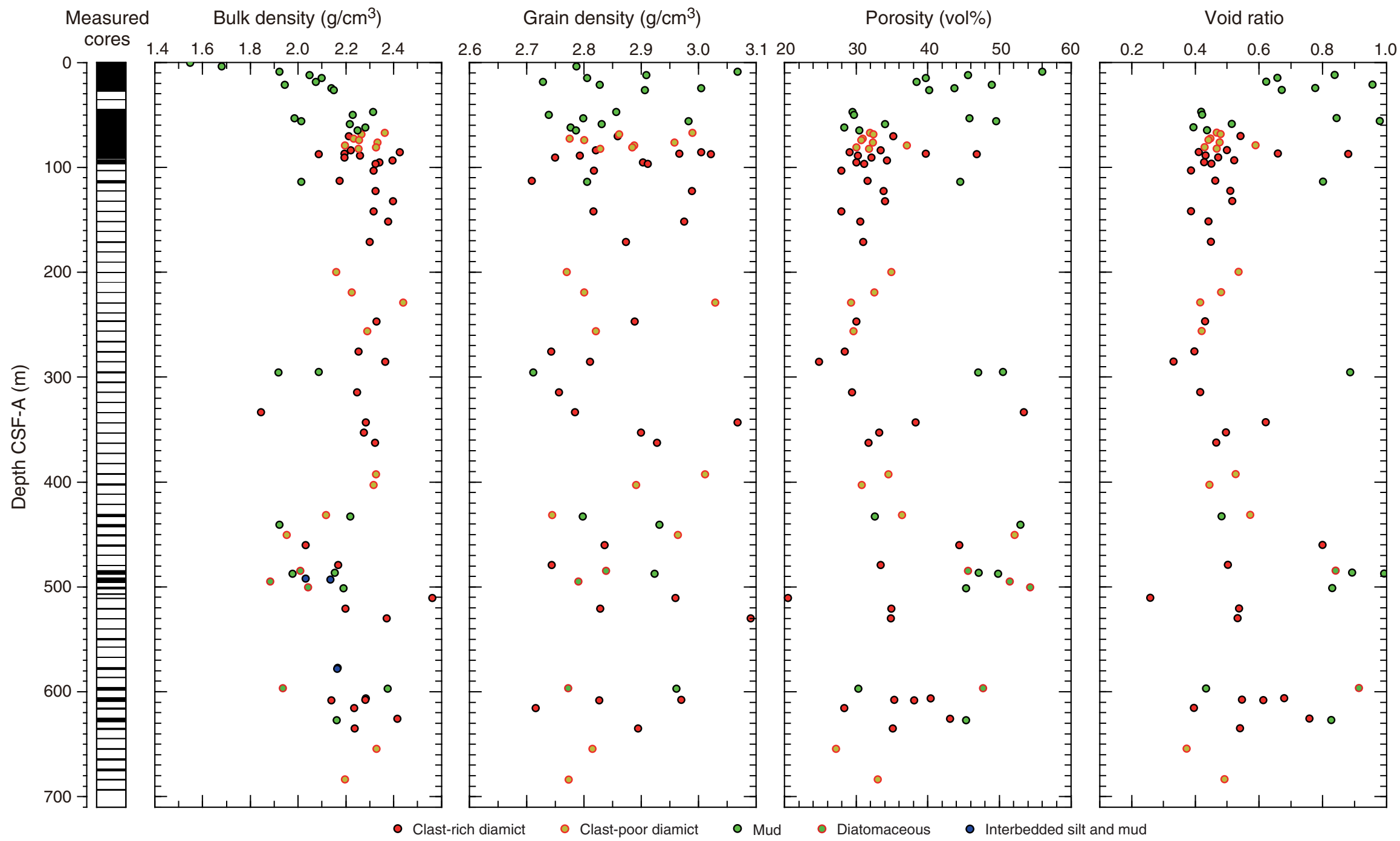
Figure F27. A. Temperature data from the advanced piston corer temperature tool, Cores 341-U1421A-4H and 6H. An exponential decrease in temperature is expected for the time interval shown, and was used to estimate ambient temperature data for the time interval $t_{\mathrm{i}}$ to $t_{\mathrm{f}}$ (solid circles) were used to estimate asymptotic temperature. B. Resulting geothermal gradient $\left(20^{\circ} \mathrm{C} / \mathrm{km}\right)$.

A

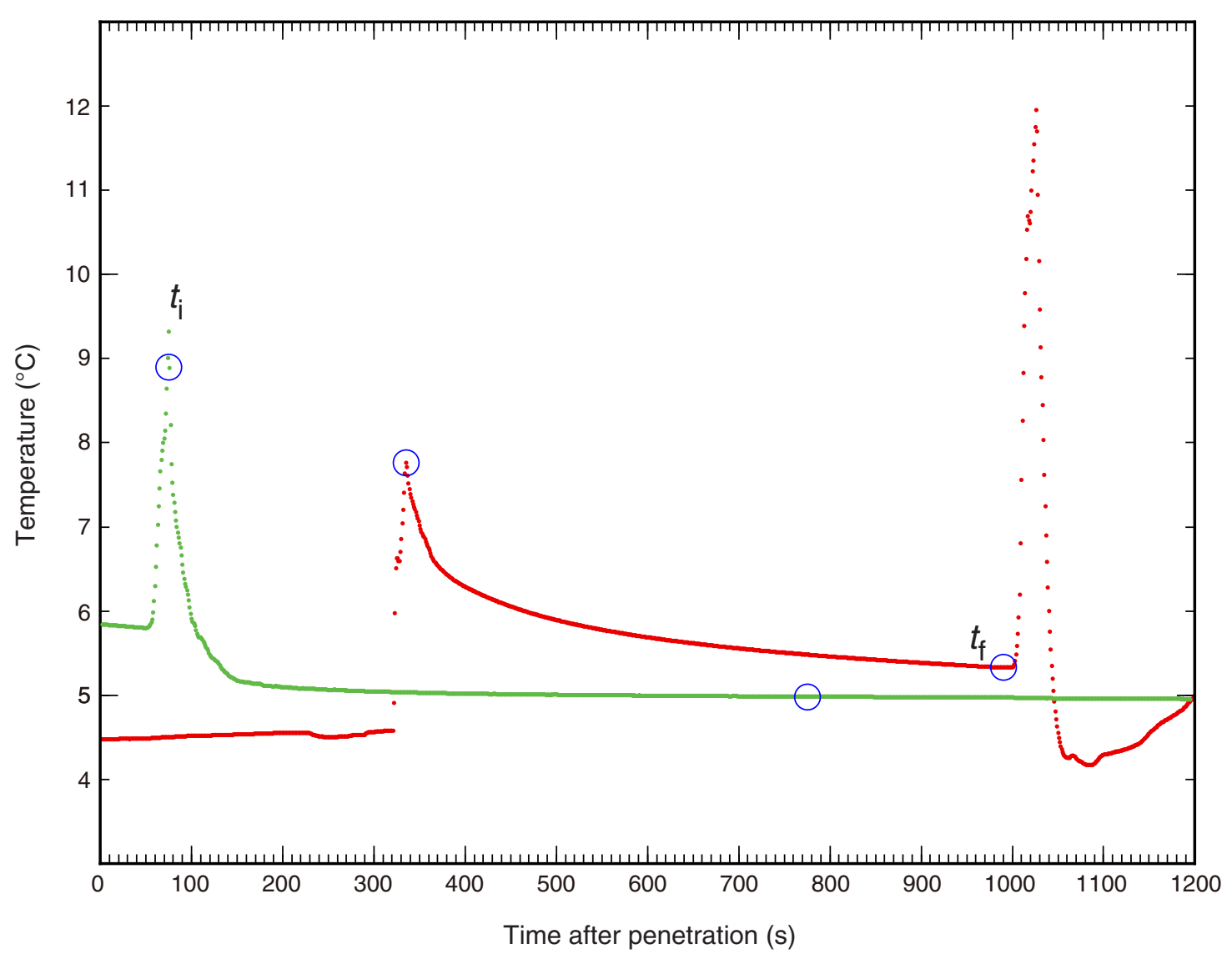

B

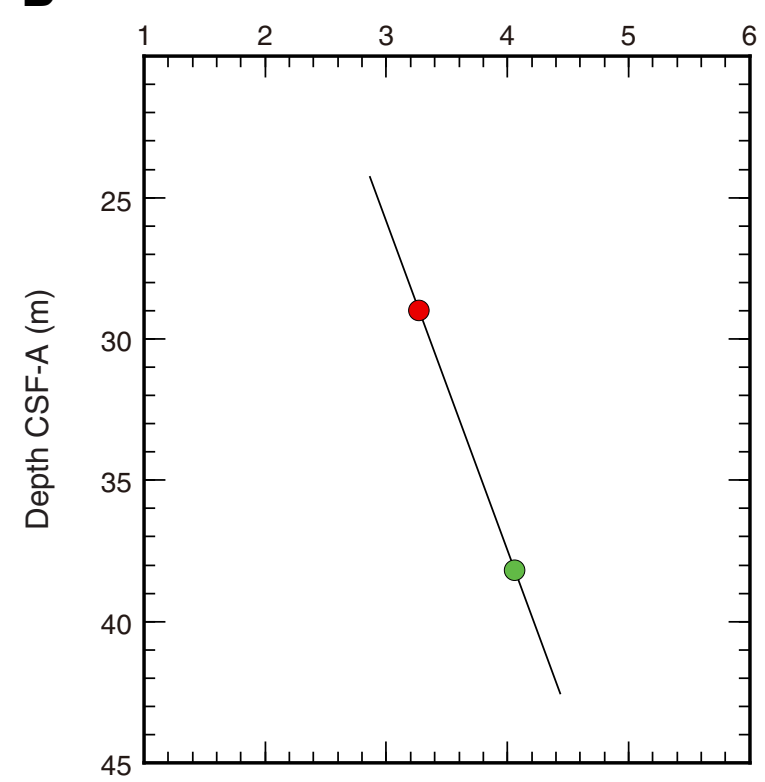


Figure F28. NRM intensity and inclination measured before and after 10 and $20 \mathrm{mT}$ peak AF demagnetization, Hole U1421A.

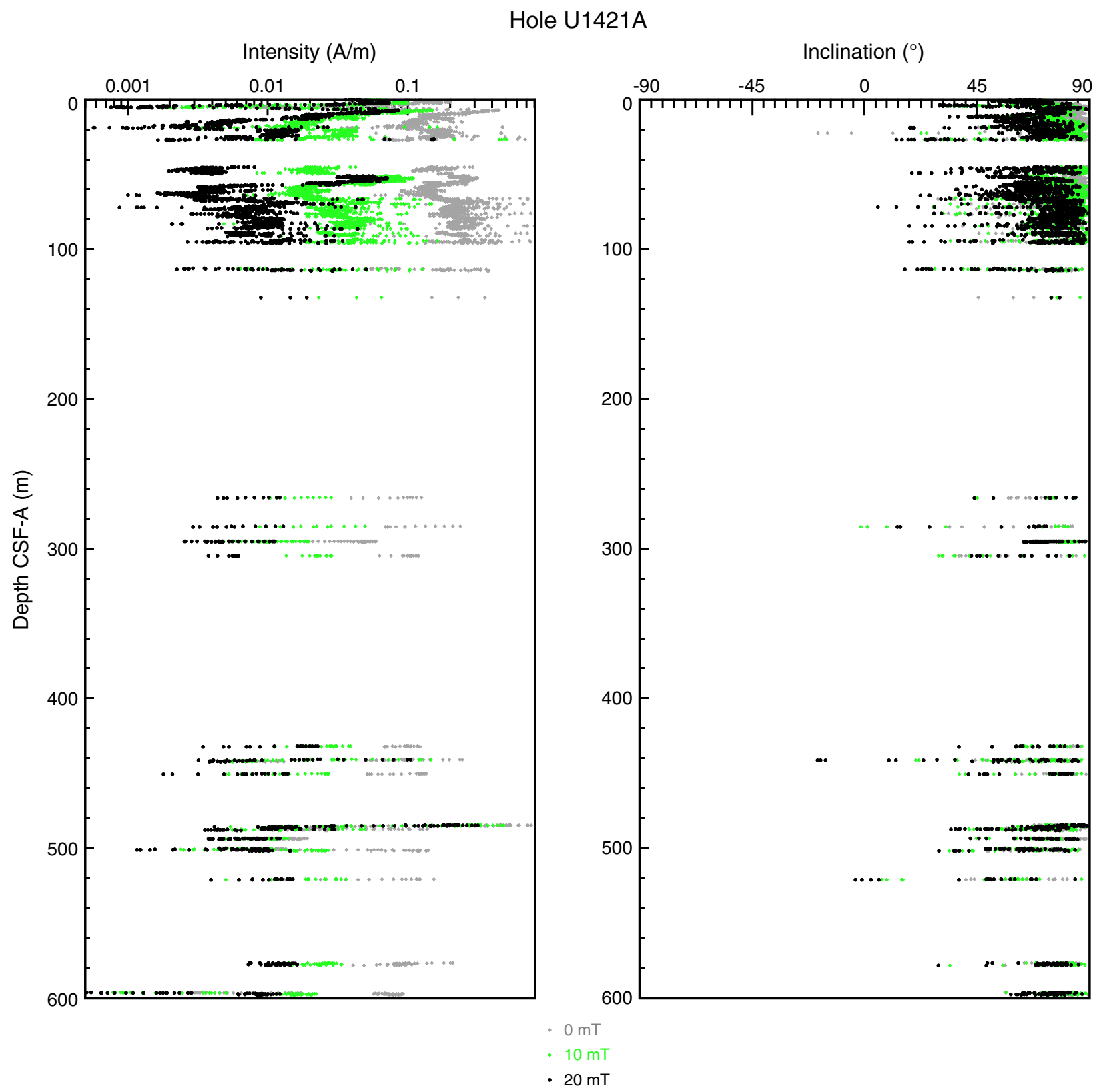


Figure F29. NRM intensity and inclination before and after 10 and $20 \mathrm{mT}$ peak AF demagnetization in recovered APC sections, Holes U1421AU1421C.
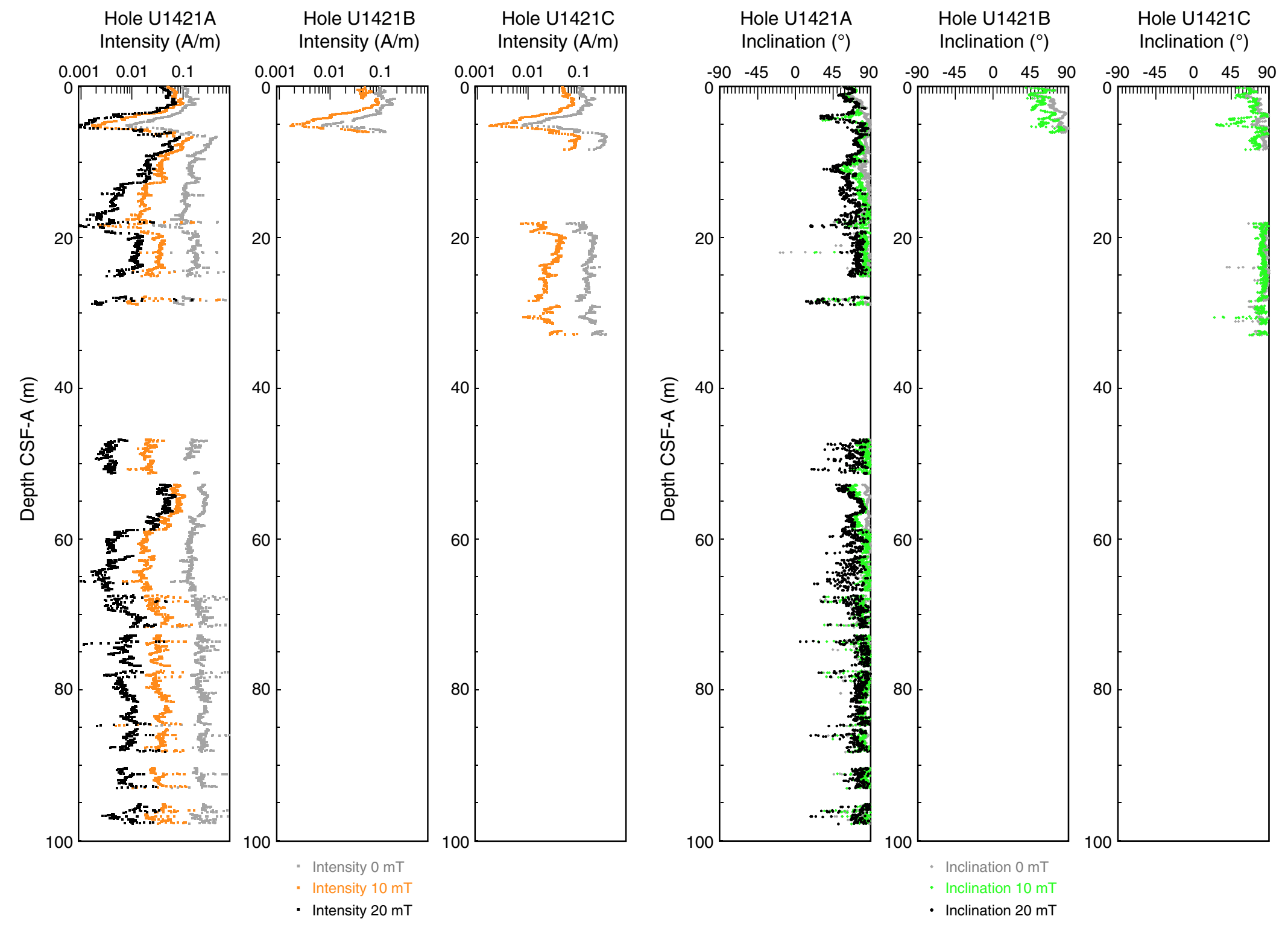
Figure F30. Logging operations summary diagram for Hole U1421A, showing wireline depths reached during different logging passes and borehole depths. See Table T6 in the "Methods" chapter (Jaeger et al., 2014) for definitions of depth scales. Stars = six depth stations that yielded good first arrival times in the vertical seismic profile (VSP).

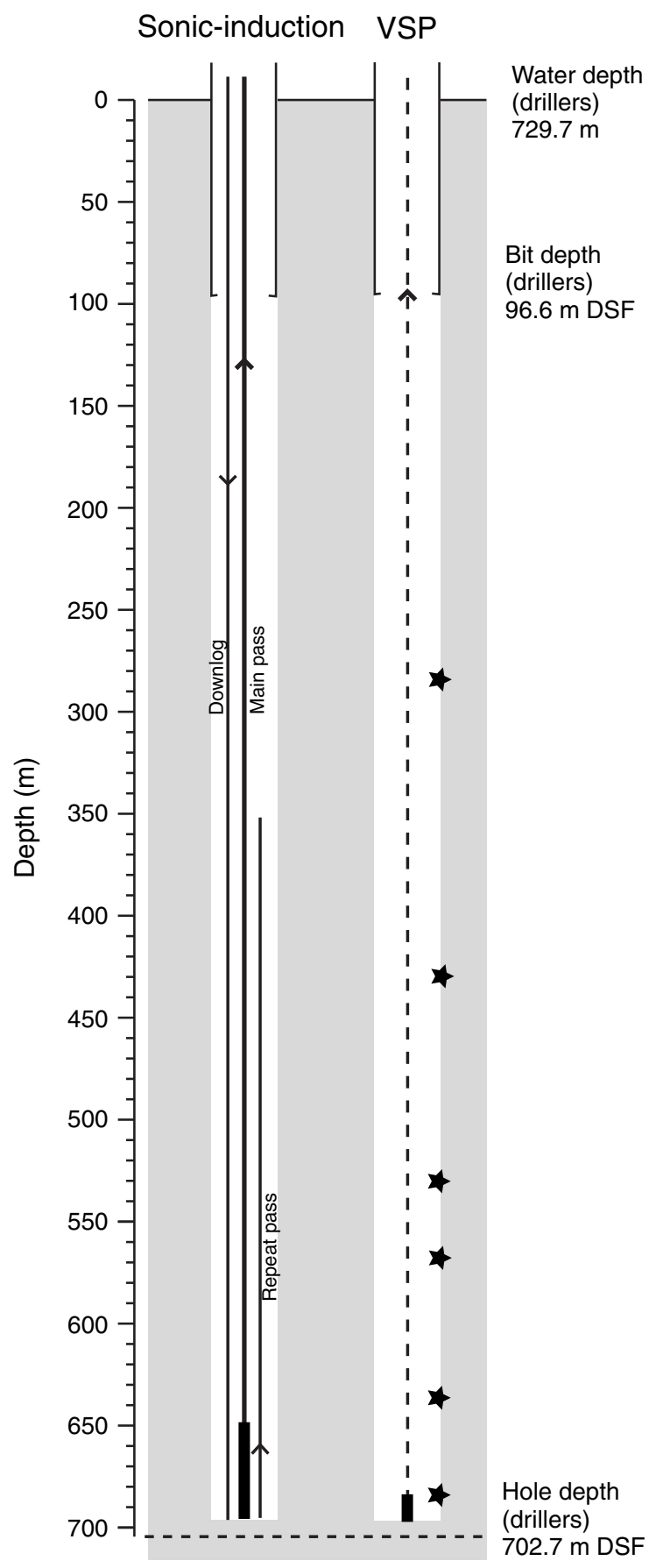


Figure F31. Summary of logs from the Sonic-induction tool string and logging units, Hole U1421A. From the Phasor Dual Induction-Spherically Focused Resistivity Tool (DIT): IDPH = deep induction log, IMPH = medium induction $\log$, SFLU $=$ shallow spherically focused resistivity $\log$.

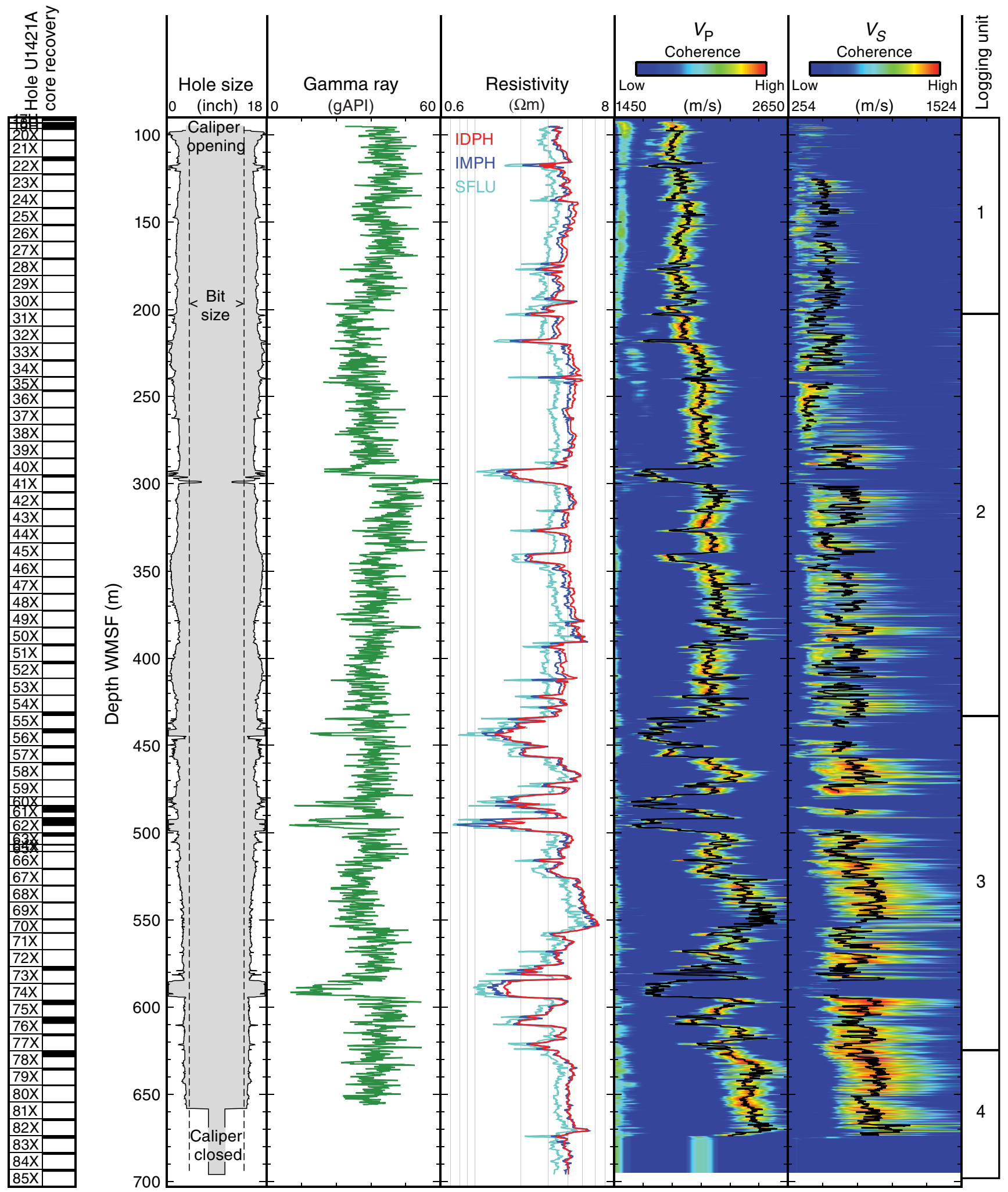


Figure F32. Comparison of the main logs recorded with the Sonic-induction tool string (gamma ray, deep induction resistivity, $P$-wave velocity), Hole U1421A. All data sets show excellent agreement between the two passes of this tool string, indicating the reliability of the various measurements.

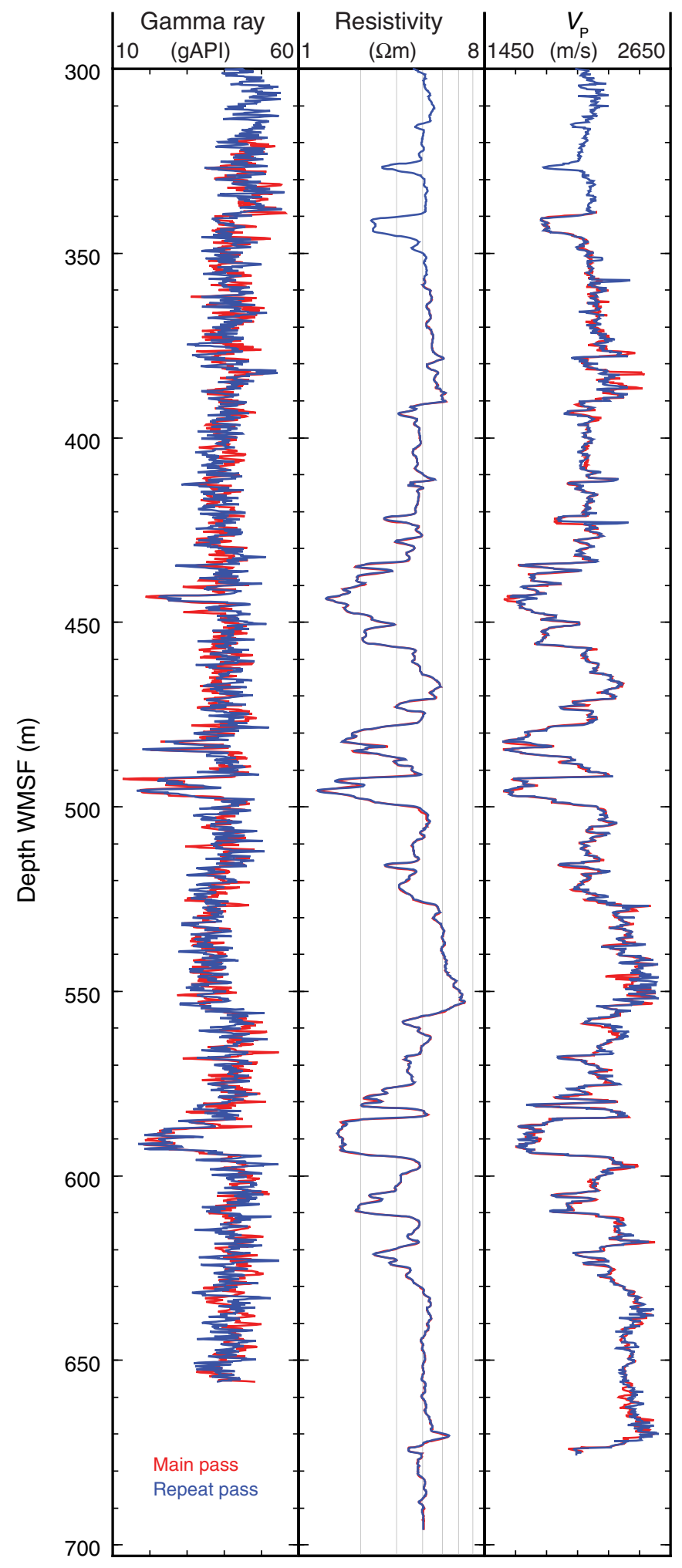


Figure F33. Comparison of gamma ray log recorded through the drill pipe and gamma ray track data from cores (uncorrected), Hole U1421A. Trends are similar, despite log signal attenuation by drill pipe. NGR = natural gamma radiation.

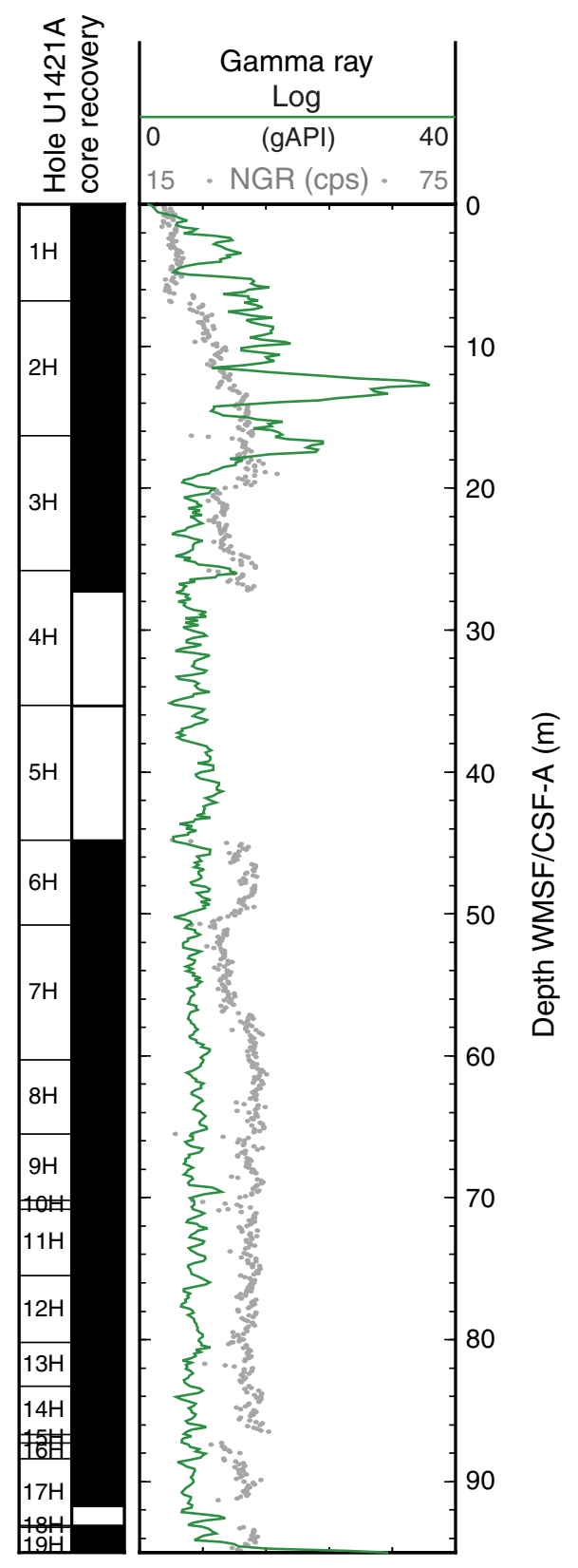


Figure F34. Vertical seismic profile waveforms and one-way arrival time picks, Hole U1421A. Red crosses = measured arrival times, green crosses $=$ arrival times corrected for depths of the air guns and hydrophone.

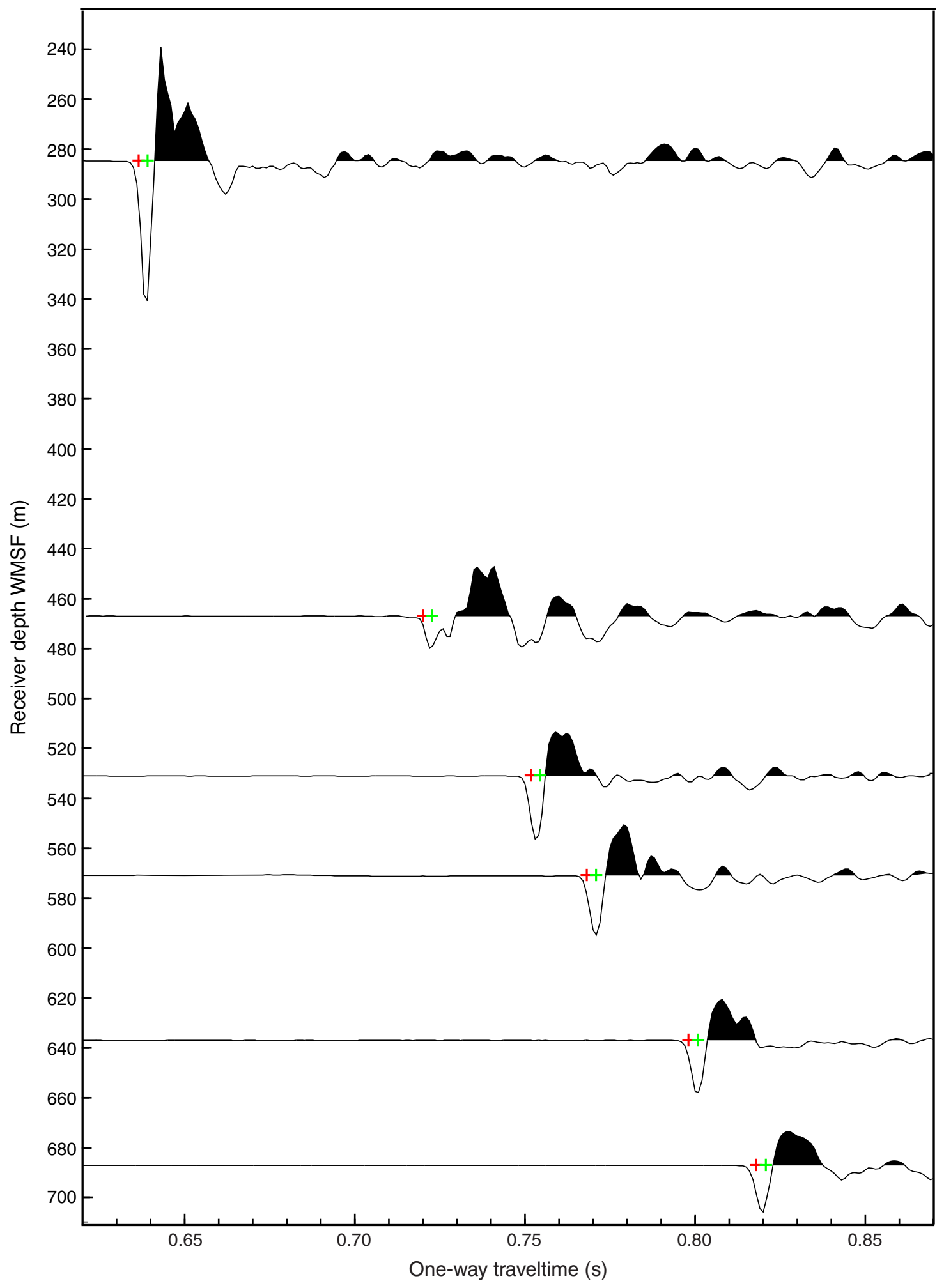


Figure F35. Comparison of lithostratigraphic units, core observations, and logging data, Site U1421. Biogenic intervals, diamict, mud with clasts, and mud with lamination are combined observations from three holes (U1421A-U1421C) and are compared to total gamma ray and resistivity measured during downhole logging in Hole U1421A.

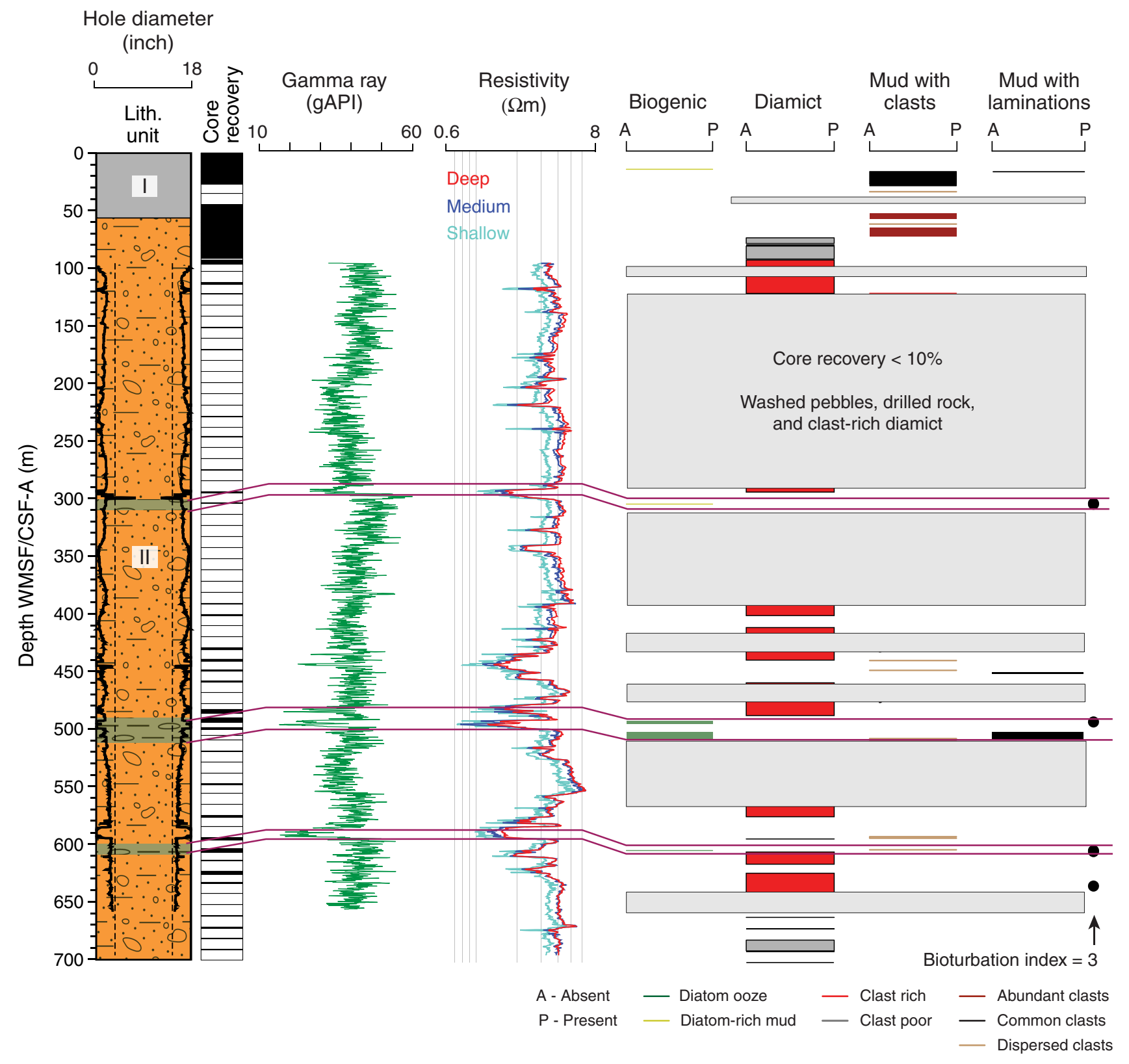


Figure F36. Comparison of downhole logging data, Hole U1421A, and core physical properties data, Site U1421. Core natural gamma radiation (NGR) is volume corrected. Core $P$-wave data: solid symbols = automatic velocity picks, open symbols $=$ manual velocity picks .

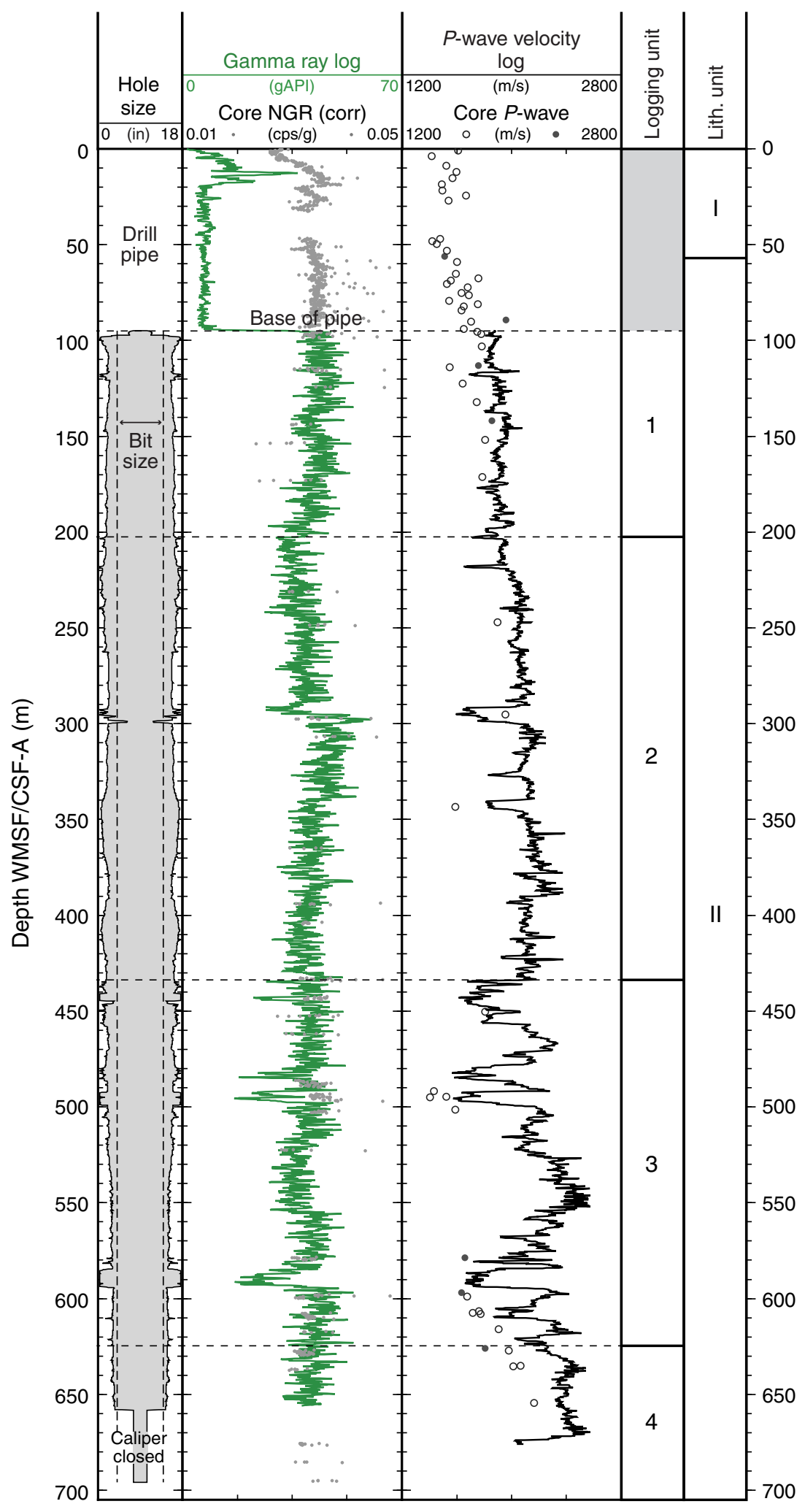


Figure F37. Integration of core, downhole logging, and seismic data, Site U1421. Two-way traveltime calculated from core $P$-wave logger (PWL) and $P$-wave caliper (PWC; solid symbols = automatic velocity picks, open symbols = manual velocity picks) measurements and from sonic log velocities (see text for details). Velocity extrapolated using downhole sonic log values from the deepest sonic log data ( 675 $\mathrm{m}$ WMSF) to the bottom of the hole.

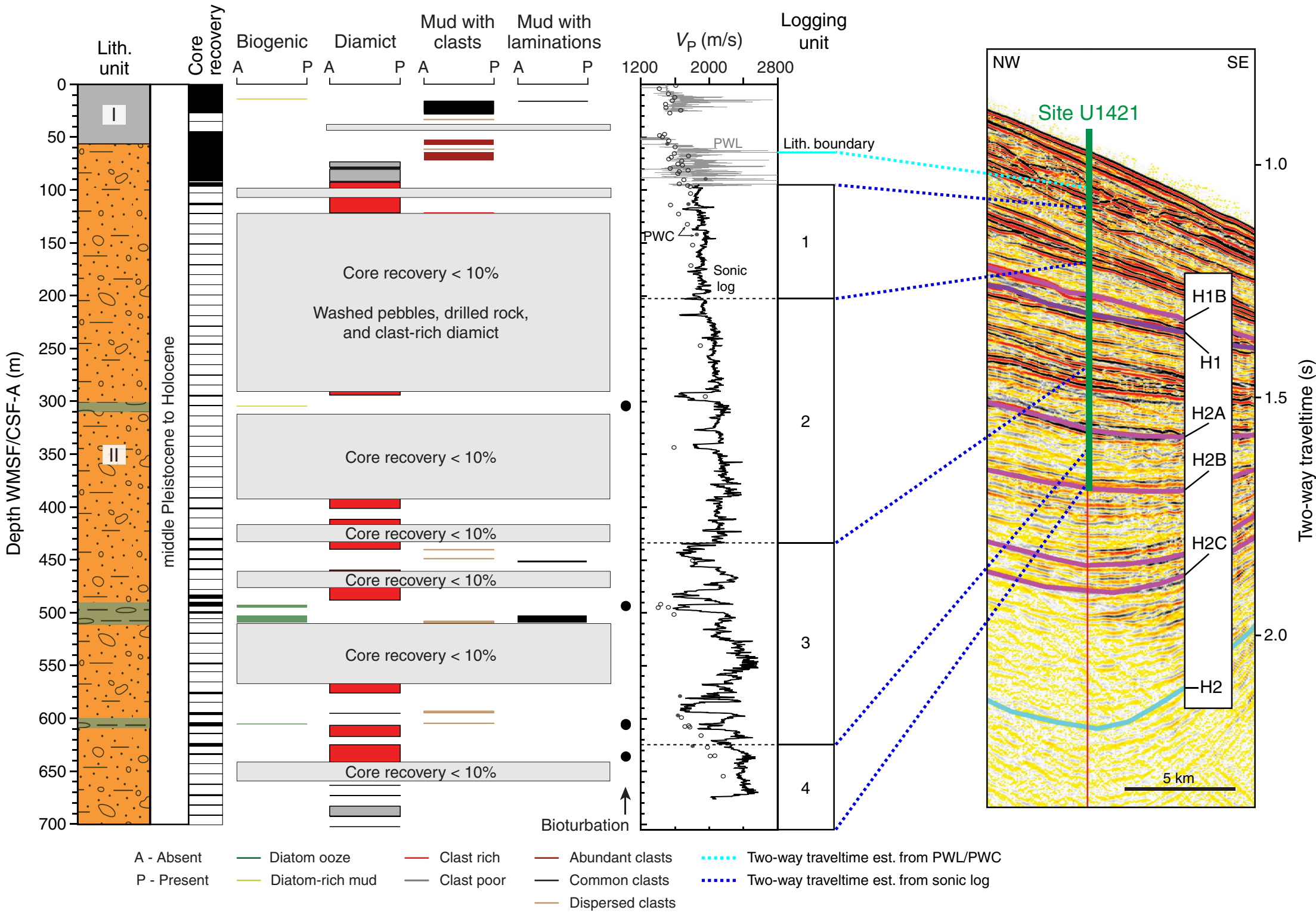


Figure F38. Seismic Profile GOA2503 acquired in 2004 aboard the R/V Maurice Ewing as part of a site survey cruise for IODP Expedition 341 (vertical resolution $=\sim 5 \mathrm{~m}$ at seafloor). Interpretations after Worthington et al. $(2008,2010)$.

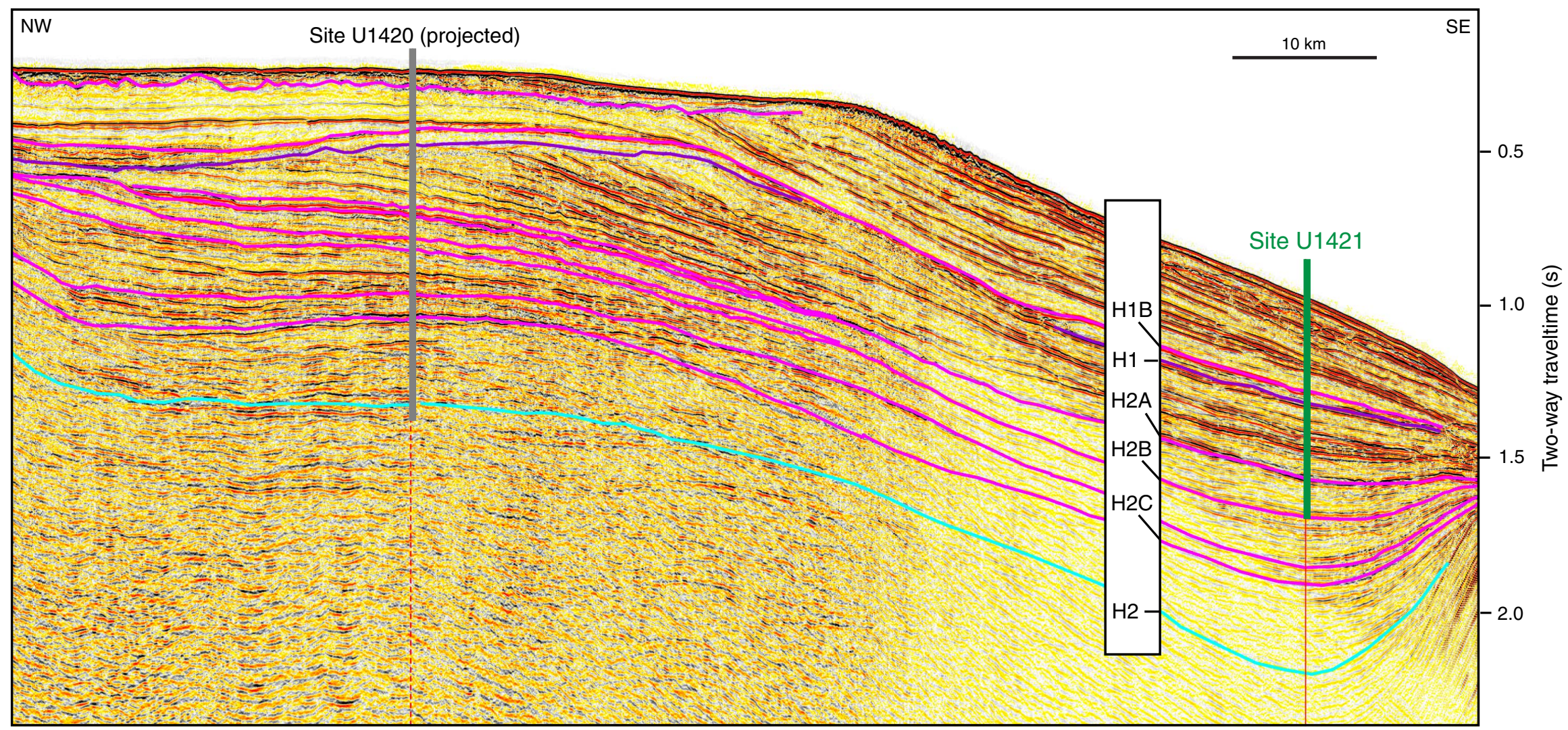


Table T1. Coring summary, Site U1421. (Continued on next two pages.)

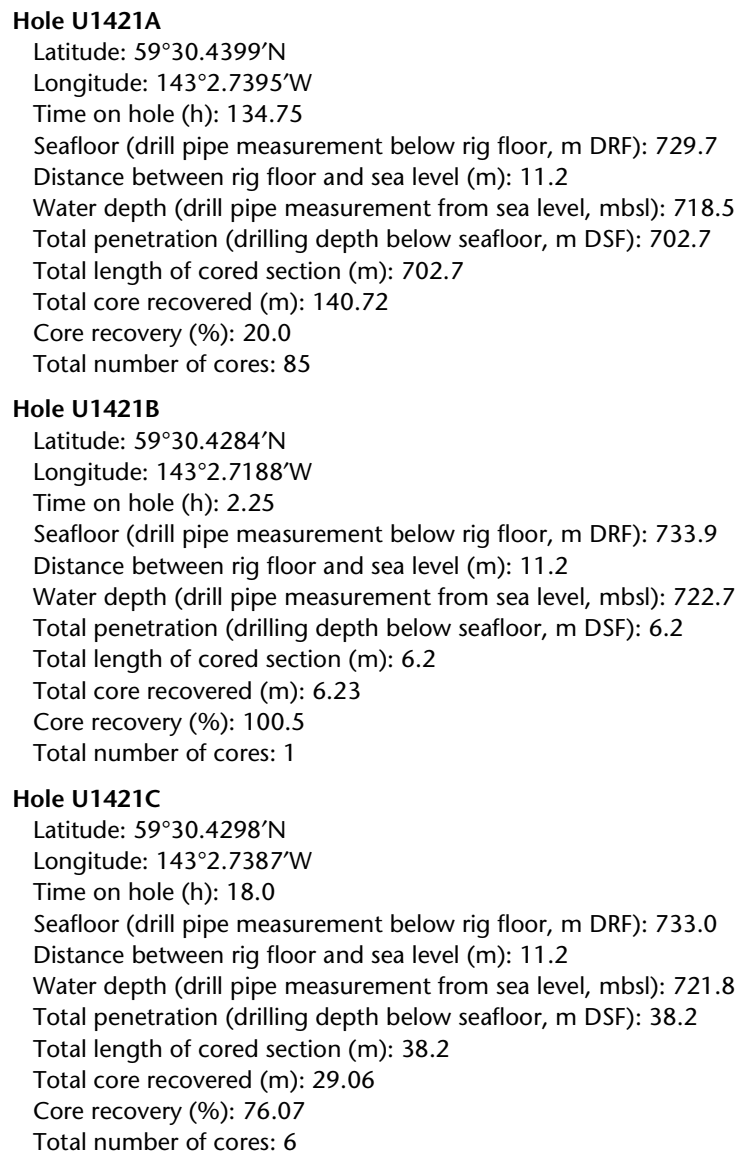

Hole U1421B

Latitude: $59^{\circ} 30.4284^{\prime} \mathrm{N}$

Longitude: $143^{\circ} 2.7188^{\prime} \mathrm{W}$

Time on hole (h): 2.25

Seafloor (drill pipe measurement below rig floor, $\mathrm{m}$ DRF): 733.9

Distance between rig floor and sea level $(\mathrm{m}): 11.2$

Water depth (drill pipe measurement from sea level, mbsl): 722.7

Total penetration (drilling depth below seafloor, $\mathrm{m} \mathrm{DSF}$ ): 6.2

Total length of cored section (m): 6.2

Total core recovered $(\mathrm{m}): 6.23$

Core recovery (\%): 100.5

Total number of cores: 1

\section{Hole U1421C}

Latitude: $59^{\circ} 30.4298^{\prime} \mathrm{N}$

Longitude: $143^{\circ} 2.7387^{\prime} \mathrm{W}$

Time on hole (h): 18.0

Seafloor (drill pipe measurement below rig floor, $\mathrm{m}$ DRF): 733.0

Distance between rig floor and sea level $(\mathrm{m}): 11.2$

Water depth (drill pipe measurement from sea level, mbsl): 721.8

Total penetration (drilling depth below seafloor, $\mathrm{m}$ DSF): 38.2

Total length of cored section $(\mathrm{m}): 38.2$

Total core recovered $(\mathrm{m}): 29.06$

Core recovery (\%): 76.07

Total number of cores: 6

\begin{tabular}{|c|c|c|c|c|c|c|c|c|c|c|c|}
\hline \multirow[b]{2}{*}{ Core } & \multirow[b]{2}{*}{$\begin{array}{l}\text { Date } \\
(2013)\end{array}$} & \multirow[b]{2}{*}{$\begin{array}{l}\text { UTC time } \\
\text { (h) }\end{array}$} & \multicolumn{2}{|c|}{ Depth DSF (m) } & \multirow[b]{2}{*}{$\begin{array}{l}\text { Interval } \\
\text { advanced } \\
(\mathrm{m})\end{array}$} & \multicolumn{2}{|c|}{ Depth CSF (m) } & \multirow{2}{*}{$\begin{array}{l}\text { Length } \\
\text { of core } \\
\text { recovered } \\
\quad(\mathrm{m})\end{array}$} & \multirow[b]{2}{*}{$\begin{array}{l}\text { Recovery } \\
(\%)\end{array}$} & \multirow[b]{2}{*}{$\begin{array}{l}\text { Sections } \\
(N)\end{array}$} & \multirow[b]{2}{*}{$\begin{array}{c}\text { APC } \\
\text { system }\end{array}$} \\
\hline & & & $\begin{array}{c}\text { Top } \\
\text { of cored } \\
\text { interval }\end{array}$ & $\begin{array}{l}\text { Bottom } \\
\text { of cored } \\
\text { interval }\end{array}$ & & $\begin{array}{c}\text { Top } \\
\text { of cored } \\
\text { interval }\end{array}$ & $\begin{array}{l}\text { Bottom } \\
\text { of cored } \\
\text { interval }\end{array}$ & & & & \\
\hline \multicolumn{12}{|c|}{ 341-U1421A- } \\
\hline $1 \mathrm{H}$ & $22 \mathrm{Jul}$ & 1610 & 0.00 & 6.80 & 6.8 & 0.00 & 6.82 & 6.82 & 100 & 6 & Full \\
\hline $2 \mathrm{H}$ & $22 \mathrm{Jul}$ & 1700 & 6.80 & 16.30 & 9.5 & 6.80 & 16.55 & 9.75 & 103 & 8 & Full \\
\hline $3 \mathrm{H}$ & $22 \mathrm{Jul}$ & 1735 & 16.30 & 25.80 & 9.5 & 16.30 & 25.96 & 9.66 & 102 & 8 & Full \\
\hline $4 \mathrm{H}$ & $22 \mathrm{Jul}$ & 1815 & 25.80 & 35.30 & 9.5 & 25.80 & 27.30 & 1.50 & 16 & 2 & Full \\
\hline $5 \mathrm{H}$ & $22 \mathrm{Jul}$ & 1930 & 35.30 & 44.80 & 9.5 & 35.30 & 35.40 & 0.10 & 1 & 1 & Full \\
\hline $6 \mathrm{H}$ & $22 \mathrm{Jul}$ & 2035 & 44.80 & 50.80 & 6.0 & 44.80 & 50.87 & 6.07 & 101 & 5 & Full \\
\hline $7 \mathrm{H}$ & $22 \mathrm{Jul}$ & 2140 & 50.80 & 60.30 & 9.5 & 50.80 & 60.51 & 9.71 & 102 & 8 & Full \\
\hline $8 \mathrm{H}$ & $22 \mathrm{Jul}$ & 2215 & 60.30 & 65.50 & 5.2 & 60.30 & 65.54 & 5.24 & 101 & 5 & Full \\
\hline $9 \mathrm{H}$ & $22 \mathrm{Jul}$ & 2330 & 65.50 & 70.20 & 4.7 & 65.50 & 70.30 & 4.80 & 102 & 4 & Half \\
\hline $10 \mathrm{H}$ & $23 \mathrm{Jul}$ & 0025 & 70.20 & 70.80 & 0.6 & 70.20 & 70.87 & 0.67 & 112 & 2 & Half \\
\hline $11 \mathrm{H}$ & $23 \mathrm{Jul}$ & 0100 & 70.80 & 75.50 & 4.7 & 70.80 & 75.74 & 4.94 & 105 & 5 & Half \\
\hline $12 \mathrm{H}$ & $23 \mathrm{Jul}$ & 0200 & 75.50 & 80.20 & 4.7 & 75.50 & 80.43 & 4.93 & 105 & 5 & Half \\
\hline $13 \mathrm{H}$ & $23 \mathrm{Jul}$ & 0235 & 80.20 & 83.30 & 3.1 & 80.20 & 83.36 & 3.16 & 102 & 3 & Half \\
\hline $14 \mathrm{H}$ & $23 \mathrm{Jul}$ & 0315 & 83.30 & 86.70 & 3.4 & 83.30 & 86.78 & 3.48 & 102 & 4 & Half \\
\hline $15 \mathrm{H}$ & 23 Jul & 0420 & 86.70 & 87.30 & 0.6 & 86.70 & 87.37 & 0.67 & 112 & 2 & Half \\
\hline $16 \mathrm{H}$ & $23 \mathrm{Jul}$ & 0510 & 87.30 & 88.40 & 1.1 & 87.30 & 88.41 & 1.11 & 101 & 2 & Half \\
\hline $17 \mathrm{H}$ & 23 Jul & 0545 & 88.40 & 93.10 & 4.7 & 88.40 & 91.76 & 3.36 & 71 & 3 & Half \\
\hline $18 \mathrm{H}$ & $23 \mathrm{Jul}$ & 0620 & 93.10 & 93.20 & 0.1 & 93.10 & 93.13 & 0.03 & 30 & 1 & Half \\
\hline $19 \mathrm{H}$ & 23 Jul & 0825 & 93.20 & 96.40 & 3.2 & 93.20 & 96.38 & 3.18 & 99 & 3 & Half \\
\hline $20 x$ & $23 \mathrm{Jul}$ & 0930 & 96.40 & 102.90 & 6.5 & 96.40 & 96.97 & 0.57 & 9 & 1 & \\
\hline $21 x$ & $23 \mathrm{Jul}$ & 1015 & 102.90 & 112.60 & 9.7 & 102.90 & 103.28 & 0.38 & 4 & 1 & \\
\hline $22 x$ & $23 \mathrm{Jul}$ & 1105 & 112.60 & 122.30 & 9.7 & 112.60 & 114.70 & 2.10 & 22 & 3 & \\
\hline $23 x$ & $23 \mathrm{Jul}$ & 1200 & 122.30 & 132.00 & 9.7 & 122.30 & 122.96 & 0.66 & 7 & 1 & \\
\hline $24 X$ & $23 \mathrm{Jul}$ & 1250 & 132.00 & 141.70 & 9.7 & 132.00 & 132.50 & 0.50 & 5 & 1 & \\
\hline $25 X$ & $23 \mathrm{Jul}$ & 1345 & 141.70 & 151.40 & 9.7 & 141.70 & 142.24 & 0.54 & 6 & 1 & \\
\hline $26 X$ & $23 \mathrm{Jul}$ & 1435 & 151.40 & 161.10 & 9.7 & 151.40 & 152.10 & 0.70 & 7 & 1 & \\
\hline $27 X$ & $23 \mathrm{Jul}$ & 1535 & 161.10 & 170.80 & 9.7 & 161.10 & 161.27 & 0.17 & 2 & 1 & \\
\hline
\end{tabular}


Table T1 (continued). (Continued on next page.)

\begin{tabular}{|c|c|c|c|c|c|c|c|c|c|c|c|}
\hline \multirow[b]{2}{*}{ Core } & \multirow[b]{2}{*}{$\begin{array}{c}\text { Date } \\
\text { (2013) }\end{array}$} & \multirow[b]{2}{*}{$\begin{array}{l}\text { UTC time } \\
\text { (h) }\end{array}$} & \multicolumn{2}{|c|}{ Depth DSF (m) } & \multirow[b]{2}{*}{$\begin{array}{l}\text { Interval } \\
\text { advanced } \\
(\mathrm{m})\end{array}$} & \multicolumn{2}{|c|}{ Depth CSF (m) } & \multirow{2}{*}{$\begin{array}{l}\text { Length } \\
\text { of core } \\
\text { recovered } \\
\quad(\mathrm{m})\end{array}$} & \multirow[b]{2}{*}{$\begin{array}{l}\text { Recovery } \\
\text { (\%) }\end{array}$} & \multirow[b]{2}{*}{$\begin{array}{l}\text { Sections } \\
(N)\end{array}$} & \\
\hline & & & $\begin{array}{c}\text { Top } \\
\text { of cored } \\
\text { interval }\end{array}$ & $\begin{array}{l}\text { Bottom } \\
\text { of cored } \\
\text { interval }\end{array}$ & & $\begin{array}{c}\text { Top } \\
\text { of cored } \\
\text { interval }\end{array}$ & $\begin{array}{l}\text { Bottom } \\
\text { of cored } \\
\text { interval }\end{array}$ & & & & $\begin{array}{c}\text { APC } \\
\text { system }\end{array}$ \\
\hline $28 \mathrm{X}$ & $23 \mathrm{Jul}$ & 1640 & 170.80 & 180.50 & 9.7 & 170.80 & 171.56 & 0.76 & 8 & 1 & \\
\hline $29 x$ & $23 \mathrm{Jul}$ & 1735 & 180.50 & 190.20 & 9.7 & 180.50 & 180.75 & 0.25 & 3 & 1 & \\
\hline $30 x$ & $23 \mathrm{Jul}$ & 1835 & 190.20 & 199.90 & 9.7 & 190.20 & 190.25 & 0.03 & 0 & 1 & \\
\hline $31 x$ & $23 \mathrm{Jul}$ & 1930 & 199.90 & 209.60 & 9.7 & 199.90 & 200.34 & 0.44 & 5 & 1 & \\
\hline $32 x$ & $23 \mathrm{Jul}$ & 2030 & 209.60 & 219.30 & 9.7 & 209.60 & 209.68 & 0.08 & 1 & 1 & \\
\hline $33 x$ & $23 \mathrm{Jul}$ & 2135 & 219.30 & 229.00 & 9.7 & 219.30 & 219.57 & 0.27 & 3 & 1 & \\
\hline $34 x$ & $23 \mathrm{Jul}$ & 2240 & 229.00 & 238.70 & 9.7 & 229.00 & 229.66 & 0.66 & 7 & 1 & \\
\hline $35 x$ & $24 \mathrm{Jul}$ & 0015 & 238.70 & 246.40 & 7.7 & 238.70 & 238.86 & 0.16 & 2 & 1 & \\
\hline $36 x$ & $24 \mathrm{Jul}$ & 0125 & 246.40 & 256.10 & 9.7 & 246.40 & 247.19 & 0.79 & 8 & 1 & \\
\hline $37 x$ & $24 \mathrm{Jul}$ & 0255 & 256.10 & 265.80 & 9.7 & 256.10 & 256.48 & 0.38 & 4 & 1 & \\
\hline $38 \mathrm{X}$ & $24 \mathrm{Jul}$ & 0440 & 265.80 & 275.50 & 9.7 & 265.80 & 266.34 & 0.54 & 6 & 1 & \\
\hline $39 x$ & $24 \mathrm{Jul}$ & 0620 & 275.50 & 285.20 & 9.7 & 275.50 & 276.07 & 0.57 & 6 & 1 & \\
\hline $40 x$ & $24 \mathrm{Jul}$ & 0720 & 285.20 & 294.90 & 9.7 & 285.20 & 285.70 & 0.50 & 5 & 1 & \\
\hline $41 x$ & $24 \mathrm{Jul}$ & 0825 & 294.90 & 304.60 & 9.7 & 294.90 & 296.21 & 1.31 & 14 & 2 & \\
\hline $42 x$ & $24 \mathrm{Jul}$ & 0935 & 304.60 & 314.30 & 9.7 & 304.60 & 305.33 & 0.73 & 8 & 1 & \\
\hline $43 x$ & $24 \mathrm{Jul}$ & 1055 & 314.30 & 324.00 & 9.7 & 314.30 & 314.83 & 0.53 & 5 & 1 & \\
\hline $44 X$ & $24 \mathrm{Jul}$ & 1155 & 324.00 & 333.70 & 9.7 & 324.00 & 324.49 & 0.49 & 5 & 1 & \\
\hline $45 x$ & $24 \mathrm{Jul}$ & 1300 & 333.70 & 343.40 & 9.7 & 333.70 & 334.20 & 0.50 & 5 & 1 & \\
\hline $46 x$ & $24 \mathrm{Jul}$ & 1405 & 343.40 & 353.10 & 9.7 & 343.40 & 343.67 & 0.27 & 3 & 1 & \\
\hline $47 x$ & $24 \mathrm{Jul}$ & 1525 & 353.10 & 362.80 & 9.7 & 353.10 & 353.59 & 0.49 & 5 & 1 & \\
\hline $48 \mathrm{X}$ & $24 \mathrm{Jul}$ & 1650 & 362.80 & 372.50 & 9.7 & 362.80 & 363.30 & 0.50 & 5 & 1 & \\
\hline $49 x$ & $24 \mathrm{Jul}$ & 1815 & 372.50 & 382.20 & 9.7 & 372.50 & 372.96 & 0.46 & 5 & 1 & \\
\hline $50 x$ & $24 \mathrm{Jul}$ & 2000 & 382.20 & 391.90 & 9.7 & 382.20 & 382.69 & 0.49 & 5 & 1 & \\
\hline $51 X$ & $24 \mathrm{Jul}$ & 2155 & 391.90 & 401.60 & 9.7 & 391.90 & 392.82 & 0.92 & 9 & 1 & \\
\hline $52 X$ & $24 \mathrm{Jul}$ & 2315 & 401.60 & 411.30 & 9.7 & 401.60 & 403.03 & 1.43 & 15 & 2 & \\
\hline $53 x$ & $25 \mathrm{Jul}$ & 0040 & 411.30 & 421.00 & 9.7 & 411.30 & 411.56 & 0.26 & 3 & 1 & \\
\hline $54 X$ & $25 \mathrm{Jul}$ & 0235 & 421.00 & 430.70 & 9.7 & 421.00 & 421.40 & 0.40 & 4 & 1 & \\
\hline $55 X$ & $25 \mathrm{Jul}$ & 0350 & 430.70 & 440.40 & 9.7 & 430.70 & 432.86 & 2.16 & 22 & 3 & \\
\hline $56 x$ & $25 \mathrm{Jul}$ & 0510 & 440.40 & 450.10 & 9.7 & 440.40 & 442.61 & 2.21 & 23 & 3 & \\
\hline $57 X$ & $25 \mathrm{Jul}$ & 0640 & 450.10 & 459.80 & 9.7 & 450.10 & 451.49 & 1.39 & 14 & 2 & \\
\hline $58 \mathrm{X}$ & $25 \mathrm{Jul}$ & 0800 & 459.80 & 469.50 & 9.7 & 459.80 & 461.00 & 1.20 & 12 & 2 & \\
\hline $59 x$ & $25 \mathrm{Jul}$ & 0910 & 469.50 & 479.20 & 9.7 & 469.50 & 469.83 & 0.33 & 3 & 1 & \\
\hline $60 x$ & $25 \mathrm{Jul}$ & 1040 & 479.20 & 484.30 & 5.1 & 479.20 & 479.57 & 0.37 & 7 & 1 & \\
\hline $61 x$ & $25 \mathrm{Jul}$ & 1200 & 484.30 & 491.30 & 7.0 & 484.30 & 488.17 & 3.87 & 55 & 4 & \\
\hline $62 X$ & $25 \mathrm{Jul}$ & 1415 & 491.30 & 500.00 & 8.7 & 491.30 & 495.78 & 4.48 & 51 & 4 & \\
\hline $63 x$ & $25 \mathrm{Jul}$ & 1600 & 500.00 & 506.70 & 6.7 & 500.00 & 502.00 & 2.00 & 30 & 3 & \\
\hline $64 X$ & $25 \mathrm{Jul}$ & 1725 & 506.70 & 506.80 & 0.1 & 506.70 & 506.70 & 0.00 & 0 & 0 & \\
\hline $65 x$ & $25 \mathrm{Jul}$ & 1920 & 506.80 & 510.70 & 3.9 & 506.80 & 507.11 & 0.31 & 8 & 1 & \\
\hline $66 x$ & $25 \mathrm{Jul}$ & 2115 & 510.70 & 520.40 & 9.7 & 510.70 & 511.05 & 0.35 & 4 & 1 & \\
\hline $67 x$ & $25 \mathrm{Jul}$ & 2235 & 520.40 & 530.10 & 9.7 & 520.40 & 521.13 & 0.73 & 8 & 1 & \\
\hline $68 x$ & $26 \mathrm{Jul}$ & 0015 & 530.10 & 539.80 & 9.7 & 530.10 & 530.49 & 0.39 & 4 & 1 & \\
\hline $69 x$ & $26 \mathrm{Jul}$ & 0200 & 539.80 & 549.20 & 9.4 & 539.80 & 540.27 & 0.47 & 5 & 1 & \\
\hline $70 x$ & $26 \mathrm{Jul}$ & 0415 & 549.20 & 557.20 & 8.0 & 549.20 & 550.33 & 0.84 & 10 & 1 & \\
\hline $71 x$ & $26 \mathrm{Jul}$ & 0550 & 557.20 & 566.90 & 9.7 & 557.20 & 557.57 & 0.37 & 4 & 1 & \\
\hline $72 x$ & $26 \mathrm{Jul}$ & 0730 & 566.90 & 576.60 & 9.7 & 566.90 & 567.24 & 0.34 & 4 & 1 & \\
\hline $73 x$ & $26 \mathrm{Jul}$ & 0845 & 576.60 & 586.30 & 9.7 & 576.60 & 578.74 & 2.14 & 22 & 3 & \\
\hline $74 X$ & $26 \mathrm{Jul}$ & 0955 & 586.30 & 596.00 & 9.7 & 586.30 & 586.76 & 0.46 & 5 & 1 & \\
\hline $75 x$ & $26 \mathrm{Jul}$ & 1130 & 596.00 & 605.70 & 9.7 & 596.00 & 598.47 & 2.47 & 25 & 3 & \\
\hline $76 x$ & $26 \mathrm{Jul}$ & 1310 & 605.70 & 615.40 & 9.7 & 605.70 & 609.25 & 3.55 & 37 & 4 & \\
\hline $77 x$ & $26 \mathrm{Jul}$ & 1440 & 615.40 & 625.10 & 9.7 & 615.40 & 616.43 & 1.03 & 11 & 2 & \\
\hline $78 X$ & $26 \mathrm{Jul}$ & 1600 & 625.10 & 634.80 & 9.7 & 625.10 & 628.39 & 3.29 & 34 & 3 & \\
\hline $79 x$ & $26 \mathrm{Jul}$ & 1730 & 634.80 & 644.50 & 9.7 & 634.80 & 636.06 & 1.21 & 12 & 2 & \\
\hline $80 \mathrm{X}$ & $26 \mathrm{Jul}$ & 1850 & 644.50 & 654.20 & 9.7 & 644.50 & 644.99 & 0.49 & 5 & 1 & \\
\hline $81 X$ & $26 \mathrm{Jul}$ & 2020 & 654.20 & 663.90 & 9.7 & 654.20 & 654.78 & 0.58 & 6 & 1 & \\
\hline $82 X$ & $26 \mathrm{Jul}$ & 2155 & 663.90 & 673.60 & 9.7 & 663.90 & 664.92 & 1.11 & 11 & 2 & \\
\hline $83 x$ & $26 \mathrm{Jul}$ & 2315 & 673.60 & 683.30 & 9.7 & 673.60 & 675.26 & 1.66 & 17 & 2 & \\
\hline $84 X$ & $27 \mathrm{Jul}$ & 0100 & 683.30 & 693.00 & 9.7 & 683.30 & 684.26 & 0.96 & 10 & 2 & \\
\hline $85 x$ & $27 \mathrm{Jul}$ & 0310 & 693.00 & 702.70 & 9.7 & 693.00 & 693.95 & 0.95 & 10 & 1 & \\
\hline 341-U14 & & & & & & & & & & & \\
\hline $1 \mathrm{H}$ & $28 \mathrm{Jul}$ & 0335 & 0.00 & 6.20 & 6.2 & 0.00 & 6.23 & 6.23 & 100 & 1 & Full \\
\hline 341-U14 & & & & & & & & & & & \\
\hline $1 \mathrm{H}$ & $28 \mathrm{Jul}$ & 0415 & 0.00 & 8.50 & 8.5 & 0.00 & 8.57 & 8.57 & 101 & 7 & Full \\
\hline $2 \mathrm{H}$ & $28 \mathrm{Jul}$ & 0510 & 8.50 & 18.00 & 9.5 & 8.50 & 8.62 & 0.12 & 1 & 1 & Full \\
\hline $3 \mathrm{H}$ & $28 \mathrm{Jul}$ & 0700 & 18.00 & 27.50 & 9.5 & 18.00 & 27.92 & 9.92 & 104 & 8 & Full \\
\hline $4 \mathrm{H}$ & $28 \mathrm{Jul}$ & 0750 & 27.50 & 29.00 & 1.5 & 27.50 & 28.99 & 1.49 & 99 & 2 & Full \\
\hline $5 \mathrm{H}$ & $28 \mathrm{Jul}$ & 0835 & 29.00 & 33.70 & 4.7 & 29.00 & 33.44 & 4.44 & 94 & 4 & Half \\
\hline
\end{tabular}


Table T1 (continued).

\begin{tabular}{|c|c|c|c|c|c|c|c|c|c|c|c|}
\hline \multirow[b]{2}{*}{ Core } & \multirow[b]{2}{*}{$\begin{array}{l}\text { Date } \\
(2013)\end{array}$} & \multirow[b]{2}{*}{$\begin{array}{l}\text { UTC time } \\
\text { (h) }\end{array}$} & \multicolumn{2}{|c|}{ Depth DSF (m) } & \multirow[b]{2}{*}{$\begin{array}{l}\text { Interval } \\
\text { advanced } \\
(\mathrm{m})\end{array}$} & \multicolumn{2}{|c|}{ Depth CSF (m) } & \multirow{2}{*}{$\begin{array}{l}\text { Length } \\
\text { of core } \\
\text { recovered } \\
\text { (m) }\end{array}$} & \multirow[b]{2}{*}{$\begin{array}{l}\text { Recovery } \\
\text { (\%) }\end{array}$} & \multirow[b]{2}{*}{$\begin{array}{l}\text { Sections } \\
(N)\end{array}$} & \multirow[b]{2}{*}{$\begin{array}{c}\text { APC } \\
\text { system }\end{array}$} \\
\hline & & & $\begin{array}{c}\text { Top } \\
\text { of cored } \\
\text { interval }\end{array}$ & $\begin{array}{l}\text { Bottom } \\
\text { of cored } \\
\text { interval }\end{array}$ & & $\begin{array}{c}\text { Top } \\
\text { of cored } \\
\text { interval }\end{array}$ & $\begin{array}{l}\text { Bottom } \\
\text { of cored } \\
\text { interval }\end{array}$ & & & & \\
\hline $6 \mathrm{H}$ & $28 \mathrm{Jul}$ & 1535 & 33.70 & 38.20 & 4.5 & 33.70 & 38.22 & 4.52 & 100 & 5 & Half \\
\hline
\end{tabular}

DSF = drilling depth below seafloor, $\mathrm{CSF}=$ core depth below seafloor. Core: $\mathrm{H}=$ advanced piston corer $(\mathrm{APC})$ core, $\mathrm{X}=\mathrm{extended}$ core barrel core 
Table T2. Summary of observed lithofacies, Site U1421. (Continued on next page.)

\begin{tabular}{|c|c|c|c|c|c|c|}
\hline Main facies & Subfacies & Facies & Description & Marine microfossils & Lithostratigraphic unit & $\begin{array}{l}\text { Tentative depositional } \\
\text { environment/diagenesis }\end{array}$ \\
\hline \multirow[t]{2}{*}{ Mud } & $\begin{array}{l}\text { Massive mud with } \\
\text { lonestones }\end{array}$ & $\mathrm{F} 1 \mathrm{a}$ & $\begin{array}{l}\text { (Very) dark gray to (very) dark greenish gray; } \\
\text { Facies thickness from } 1.49 \text { to } 9.92 \mathrm{~m} \text {; } \\
\text { With dispersed to abundant clasts; } \\
\text { Occasionally diatom/biosiliceous-rich/bearing, some shell fragments; } \\
\text { Bioturbation mostly absent but occasionally heavy (typically in intervals with } \\
\text { high amounts of diatoms); } \\
\text { Angular to rounded lonestones include siltstone, sandstone, argillite, mudstone } \\
\text { breccia, metasandstone, gneiss, quartzite, basalt, rhyolite, mica schist, and } \\
\text { slate; } \\
\text { Occasional occurrence of pods of silt, sand, and granules; } \\
\text { Trace amounts of volcanic ash in Core } 341 \text {-U1421 A-41X; } \\
\text { Occasional occurrence of mud laminae (Section } 1 \mathrm{H}-5 \text { ); } \\
\text { Mud with abundant clasts can be strongly consolidated (e.g., Cores 7H and } 8 \mathrm{H} \text { ); } \\
\text { May show signs of intense soft-sediment deformation (e.g., Core } 61 \mathrm{X} \text { ); } \\
\text { Interbedded with Facies F1c, F4f, F5a, F5b, and F5c }\end{array}$ & $\begin{array}{l}\text { Diatoms, sponge } \\
\text { spicules }\end{array}$ & I, II & $\begin{array}{l}\text { Suspension fall-out, ice rafting, } \\
\text { or sediment gravity flows }\end{array}$ \\
\hline & $\begin{array}{l}\text { Massive mud } \\
\text { without lonestones }\end{array}$ & $\mathrm{F} 1 \mathrm{~b}$ & $\begin{array}{l}\text { Dark greenish gray to dark gray; } \\
\text { Facies thickness from } 5 \mathrm{~cm} \text { to } 5.95 \mathrm{~m} \text {; } \\
\text { Often diatom bearing; } \\
\text { Occasional shell fragments, foraminifers, and black mottles; } \\
\text { Bioturbation mostly absent but occasionally slight; } \\
\text { May contain lamination (e.g., Core } 341 \text {-U1421A-56X); } \\
\text { Interbedded with Facies F1a, F4f, F5a, F5b, and F7 }\end{array}$ & $\begin{array}{l}\text { Diatoms and rare } \\
\text { foraminifers }\end{array}$ & I, II & $\begin{array}{l}\text { Suspension fall-out or sediment } \\
\text { gravity flows }\end{array}$ \\
\hline \multirow[t]{3}{*}{ Diamict } & $\begin{array}{l}\text { Interbedded mud } \\
\text { and diamict }\end{array}$ & F4d & $\begin{array}{l}\text { Dark gray; } \\
\text { Facies thickness from } 24 \mathrm{~cm} \text { to } 1.31 \mathrm{~m} \text {; } \\
\text { Sandy clast-poor diamict interbedded with up to } 4 \mathrm{~cm} \text { thick mud beds and } \\
\text { laminae; } \\
\text { Diamict contains granules and pebbles of siltstone, granitoids, greenstone, and } \\
\text { sandstone; } \\
\text { Often irregular transitions between diamict and mud intervals; } \\
\text { Bioturbation is absent, and shell fragments are rare; } \\
\text { Interbedded with Facies F4f and F5a }\end{array}$ & Not documented & II & $\begin{array}{l}\text { Suspension settling and ice } \\
\text { rafting (icebergs and/or sea } \\
\text { ice) }\end{array}$ \\
\hline & Clast-poor diamict & $\mathrm{F} 4 \mathrm{e}$ & $\begin{array}{l}\text { Very dark gray; } \\
\text { Facies thickness from } 13 \mathrm{~cm} \text { to } 4.65 \mathrm{~m} \text {; } \\
\text { Mostly silty or muddy matrix, occasionally sandy matrix; } \\
\text { Subrounded to subangular granule and pebble clasts, including sandstone, } \\
\text { basalt, siltstone, argillite, metasandstone, schist, chert, granite, rhyolite, } \\
\text { granitoid, vein quartz, gneiss, marble(?), and greywacke; } \\
\text { Occasional occurrence of shell fragments; } \\
\text { Bioturbation absent; } \\
\text { Interbedded with Facies F4f and F5b }\end{array}$ & Not documented & II & $\begin{array}{l}\text { Suspension setting and ice } \\
\text { rafting (mainly by icebergs) }\end{array}$ \\
\hline & Clast-rich diamict & $\mathrm{F} 4 \mathrm{f}$ & $\begin{array}{l}\text { (Very) dark gray; } \\
\text { Facies thickness from } 3 \mathrm{~cm} \text { to } 3.44 \mathrm{~m} \text {; } \\
\text { Mostly muddy and silty matrix, often with sand; } \\
\text { Subrounded to subangular granule and pebble clasts, including siltstone, } \\
\text { sandstone, basalt, rhyolite, vein quartz, metasiltstone, greenstone, granitoid, } \\
\text { gneiss, metasandstone, argillite, mudstone, granite, diorite, conglomerate(?), } \\
\text { metasedimentary breccia, metaigneous rock, and chert; } \\
\text { Very rare shell fragments; } \\
\text { Bioturbation absent; } \\
\text { Very rare trace amounts of ash; } \\
\text { Interbedded with Faces F1a, F1c, F4d, F4e, F5b, and F7 }\end{array}$ & Not documented & ॥ & $\begin{array}{l}\text { Suspension setting and ice } \\
\text { rafting (mainly by icebergs) }\end{array}$ \\
\hline
\end{tabular}


Table T2 (continued).

\begin{tabular}{|c|c|c|c|c|c|c|}
\hline Main facies & Subfacies & Facies & Description & Marine microfossils & Lithostratigraphic unit & $\begin{array}{l}\text { Tentative depositional } \\
\text { environment/diagenesis }\end{array}$ \\
\hline Diatom ooze & & $\mathrm{F} 5 \mathrm{a}$ & $\begin{array}{l}\text { Dark greenish gray; } \\
\text { Facies thickness and } 12 \mathrm{~cm} \text { to } 1.42 \mathrm{~m} \text {; } \\
\text { Laminated (millimeter-scale) or thin bedded without bioturbation or massive } \\
\text { with slight to heavy bioturbation; } \\
\text { Absent lonestones; } \\
\text { Occasional shell fragments; } \\
\text { Interbedded with Facies F1a, F1c, and F4d }\end{array}$ & Diatoms & $\mathrm{I}, \mathrm{II}$ & $\begin{array}{l}\text { High-productivity environment } \\
\text { and/or low terrigenous input } \\
\text { and/or better preservation }\end{array}$ \\
\hline $\begin{array}{l}\text { Biosiliceous ooze; } \\
\text { biosiliceous-rich/ } \\
\text { bearing mud and/ } \\
\text { or sand; mud with } \\
\text { diatoms/biosilica }\end{array}$ & & $\mathrm{F} 5 \mathrm{~b}$ & $\begin{array}{l}\text { Dark greenish gray to (very) dark gray; } \\
\text { Facies thickness from } 19 \mathrm{~cm} \text { to } 5.95 \mathrm{~m} \text {; } \\
\text { Mud without clasts and mud with dispersed to abundant clasts; } \\
\text { Mostly diatom bearing; } \\
\text { Occasionally parallel lamination (Cores } 341-\mathrm{U} 1421 \mathrm{~A}-1 \mathrm{H} \text { and } 56 \mathrm{X} \text { ); } \\
\text { Occasional shell fragments; } \\
\text { Occasional black mottles; } \\
\text { Bioturbation mostly absent but rarely slight or heavy; } \\
\text { Rarely with foraminifers; } \\
\text { Rare traces of volcanic ash; } \\
\text { Interbedded with Facies F1a, F1c, F4e, F4f, and F7 }\end{array}$ & $\begin{array}{l}\text { Diatoms, sponge } \\
\text { spicules }\end{array}$ & $\mathrm{I}, \mathrm{II}$ & $\begin{array}{l}\text { Temporarily increased } \\
\text { productivity and/or reduced } \\
\text { suspension settling and/or } \\
\text { better preservation }\end{array}$ \\
\hline $\begin{array}{l}\text { Calcareous/ } \\
\text { carbonate- } \\
\text { bearing/rich mud, } \\
\text { silt, sand, diamict, } \\
\text { and/or diatom } \\
\text { ooze }\end{array}$ & & $\mathrm{F} 5 \mathrm{c}$ & $\begin{array}{l}\text { Grayish green; } \\
\text { Facies thickness from } 15 \text { to } 18 \mathrm{~cm} \text {; } \\
\text { One interval of diatom-rich mud with foraminifers; } \\
\text { Slight bioturbation; } \\
\text { Black mottles present; } \\
\text { Interbedded with Facies F1a }\end{array}$ & $\begin{array}{l}\text { Foraminifers, bivalve, } \\
\text { gastropod }\end{array}$ & I & $\begin{array}{l}\text { Temporarily increased } \\
\text { productivity and/or reduced } \\
\text { suspension settling and/or } \\
\text { better preservation }\end{array}$ \\
\hline $\begin{array}{l}\text { Volcaniclastic mud, } \\
\text { sand, diamict, } \\
\text { and/or ooze }\end{array}$ & & F7 & $\begin{array}{l}\text { Dark greenish gray to dark gray; } \\
\text { Facies thickness from } 46-67 \mathrm{~cm} \text {; } \\
\text { In diatom-bearing mud and clast-rich diamict; } \\
\text { Bioturbation either absent (diamict) or heavy (mud); } \\
\text { Interbedded with Facies F1c, F4f, and F5b }\end{array}$ & Not documented & II & $\begin{array}{l}\text { Volcanic detritus either } \\
\text { bioturbated or reworked/ } \\
\text { redeposited by sediment } \\
\text { gravity flows }\end{array}$ \\
\hline
\end{tabular}


Table T3. Distribution of lithostratigraphic units and associated facies, Site U1421.

\begin{tabular}{|c|c|c|c|}
\hline $\begin{array}{l}\text { Lithostratigraphic } \\
\text { units and } \\
\text { associated facies }\end{array}$ & Hole U1421A & Hole U1421B & Hole U1421C \\
\hline $\begin{array}{l}\text { Unit I } \\
\text { F1a, F1b, F5a, F5b, } \\
\text { F5c }\end{array}$ & $\begin{array}{l}\text { 0-57 m CSF-A; } \\
\text { Interval 1H-1, } 0 \mathrm{~cm} \text {, to 7H-5, } \\
20 \mathrm{~cm}\end{array}$ & $\begin{array}{l}\text { 0-6.23 m CSF-A; } \\
\text { Interval 1H-1, 0 cm, 1H-CC, } \\
18 \mathrm{~cm}\end{array}$ & $\begin{array}{l}\text { 0-38.22 m CSF-A; } \\
\text { Interval } 1 \mathrm{H}-1,0 \mathrm{~cm} \text {, to } 6 \mathrm{H}- \\
\quad \mathrm{CC}, 36 \mathrm{~cm}\end{array}$ \\
\hline $\begin{array}{l}\text { Unit II } \\
\text { F1a, F1b, F4d, F4e, } \\
\text { F4f, F5a, F5b, F7 }\end{array}$ & $\begin{array}{l}\text { 57.0-702.7 m CSF-A; } \\
\text { Interval 7H-5, } 20 \mathrm{~cm} \text {, to } \\
85 \mathrm{X}-1,95 \mathrm{~cm}\end{array}$ & & \\
\hline
\end{tabular}

Table T4. XRD mineral composition, Site U1421.

\begin{tabular}{|c|c|c|c|c|c|c|c|c|c|}
\hline $\begin{array}{l}\text { Core, section, } \\
\text { interval }(\mathrm{cm})\end{array}$ & $\begin{array}{l}\text { Top depth } \\
\text { CSF-A (m) }\end{array}$ & $\begin{array}{l}\text { Mica } \\
\text { (counts) }\end{array}$ & $\begin{array}{l}\text { Hornblende } \\
\text { (counts) }\end{array}$ & $\begin{array}{c}\text { Chlorite + } \\
\text { kaolinite } \\
\text { (counts) }\end{array}$ & $\begin{array}{l}\text { Total clays } \\
\text { (counts) }\end{array}$ & $\begin{array}{c}\text { Quartz } \\
\text { (counts) }\end{array}$ & $\begin{array}{l}\text { Plagioclase } \\
\text { (counts) }\end{array}$ & $\begin{array}{c}\text { Calcite } \\
\text { (counts) }\end{array}$ & $\begin{array}{c}\text { Pyrite } \\
\text { (counts) }\end{array}$ \\
\hline \multicolumn{10}{|l|}{ 341-U1421A- } \\
\hline $1 \mathrm{H}-1 \mathrm{~W}, 44-45$ & 0.44 & 4,643 & 5,399 & 6,294 & 2,672 & 5,503 & 6,362 & 3,645 & 2,555 \\
\hline $2 \mathrm{H}-1 \mathrm{~W}, 40-41$ & 7.20 & 6,190 & 4,712 & 7,772 & 2,672 & 7,669 & 7,944 & 4,712 & NA \\
\hline $3 \mathrm{H}-1 \mathrm{~W}, 40-41$ & 16.70 & 4,574 & 5,399 & 5,984 & 2,387 & 7,257 & 13,619 & 2,696 & 2,194 \\
\hline $4 \mathrm{H}-1 \mathrm{~W}, 40-41$ & 26.20 & 5,296 & NA & 7,738 & 2,531 & 6,225 & 15,270 & 4,402 & 2,270 \\
\hline $6 \mathrm{H}-1 \mathrm{~W}, 40-41$ & 45.20 & 6,397 & 6,431 & 10,042 & 2,490 & 6,603 & 11,487 & 3,185 & 2,242 \\
\hline $7 \mathrm{H}-1 \mathrm{~W}, 40-41$ & 51.20 & 6,844 & NA & 11,659 & 2,586 & 8,460 & 7,291 & 3,054 & 2,253 \\
\hline $8 \mathrm{H}-1 \mathrm{~W}, 40-41$ & 60.70 & 5,640 & 6,019 & 10,765 & 2,473 & 7,979 & 10,902 & 2,724 & 2,466 \\
\hline $9 \mathrm{H}-1 \mathrm{~W}, 40-41$ & 65.90 & 4,093 & 5,881 & 9,217 & 2,449 & 8,942 & 13,000 & 2,693 & 2,583 \\
\hline $10 \mathrm{H}-1 \mathrm{~W}, 40-41$ & 70.60 & 5,984 & 5,537 & 6,190 & 2,634 & 6,466 & 23,489 & 3,377 & 2,273 \\
\hline $11 \mathrm{H}-1 \mathrm{~W}, 40-41$ & 71.20 & 5,640 & 6,466 & 8,770 & 2,607 & 9,251 & 8,323 & 2,975 & 2,435 \\
\hline $12 \mathrm{H}-1 \mathrm{~W}, 40-41$ & 75.90 & 5,640 & 8,151 & 6,500 & 2,614 & 7,566 & 16,130 & 3,852 & 2,294 \\
\hline $13 \mathrm{H}-1 \mathrm{~W}, 40-41$ & 80.60 & 6,259 & 4,540 & 10,145 & 2,500 & 7,635 & 13,619 & 3,542 & 2,246 \\
\hline $14 \mathrm{H}-1 \mathrm{~W}, 133-134$ & 84.63 & 5,537 & 6,397 & 6,294 & 2,500 & 7,669 & 10,421 & 3,099 & 2,218 \\
\hline $16 \mathrm{H}-1 \mathrm{~W}, 49-50$ & 87.79 & 6,500 & 6,087 & 7,394 & 2,542 & 8,598 & 10,799 & 3,257 & 2,290 \\
\hline $17 \mathrm{H}-2 \mathrm{~W}, 110-111$ & 91.00 & 6,672 & 4,918 & 10,111 & 2,562 & 9,148 & 9,114 & 3,714 & 2,191 \\
\hline $19 \mathrm{H}-2 \mathrm{~W}, 40-41$ & 95.10 & 7,807 & 6,741 & 11,005 & 2,500 & 8,392 & 8,770 & 3,040 & 2,311 \\
\hline 31X-CCW, 9-10 & 199.99 & 4,024 & 6,053 & 10,386 & 2,528 & 8,116 & 9,664 & 3,164 & 2,235 \\
\hline $33 X-C C W, 9-10$ & 219.39 & 4,196 & 5,881 & 7,050 & 2,617 & 8,563 & 14,410 & 2,727 & 2,280 \\
\hline $34 \mathrm{X}-1 \mathrm{~W}, 9-10$ & 229.09 & 6,500 & 5,193 & 7,532 & 2,373 & 7,119 & 8,976 & 3,164 & 2,074 \\
\hline $36 X-1 W, 9-10$ & 246.49 & 7,841 & 4,643 & 10,283 & 2,445 & 9,905 & 9,354 & 3,474 & 2,971 \\
\hline $37 X-1 W, 9-10$ & 256.19 & 6,294 & 4,437 & 10,799 & 2,658 & 8,392 & 7,807 & 3,026 & 2,710 \\
\hline $38 X-1 W, 12-13$ & 265.92 & 4,918 & 5,950 & 7,429 & 2,545 & 8,701 & 18,056 & 3,425 & 2,191 \\
\hline $41 X-1 W, 30-31$ & 295.20 & 5,434 & 5,365 & 6,810 & 2,744 & 7,635 & 8,495 & 3,157 & 2,480 \\
\hline 49X-CCW, 4-5 & 372.54 & 4,161 & 6,569 & 15,339 & 2,507 & 8,529 & 12,381 & 3,284 & 2,239 \\
\hline $51 X-1 W, 4-5$ & 391.94 & 6,672 & 6,638 & 9,767 & 2,542 & 8,254 & 9,183 & 3,147 & 2,146 \\
\hline $52 \mathrm{X}-\mathrm{CCW}, 4-5$ & 402.75 & 5,296 & 6,397 & 10,593 & 2,689 & 8,839 & 14,823 & 3,302 & 2,218 \\
\hline $54 \mathrm{X}-\mathrm{CCW}, 4-5$ & 421.04 & 4,712 & 5,124 & 8,598 & 2,514 & 6,878 & 10,558 & 4,093 & 2,235 \\
\hline $55 X-1 W, 78-80$ & 431.48 & 4,093 & 4,196 & 9,458 & 2,524 & 6,913 & 14,066 & 2,951 & 2,215 \\
\hline $56 X-1 W, 64-66$ & 441.04 & 5,640 & 8,082 & 6,741 & 2,648 & 7,085 & 9,389 & 3,817 & 2,621 \\
\hline
\end{tabular}

$\mathrm{NA}=$ not applicable

Table T5. Diatoms, Site U1421. This table is available in an oversized format. 
J.M. Jaeger et al.

Site U1421

Table T6. Radiolarians, Site U1421. (Continued on next page.)

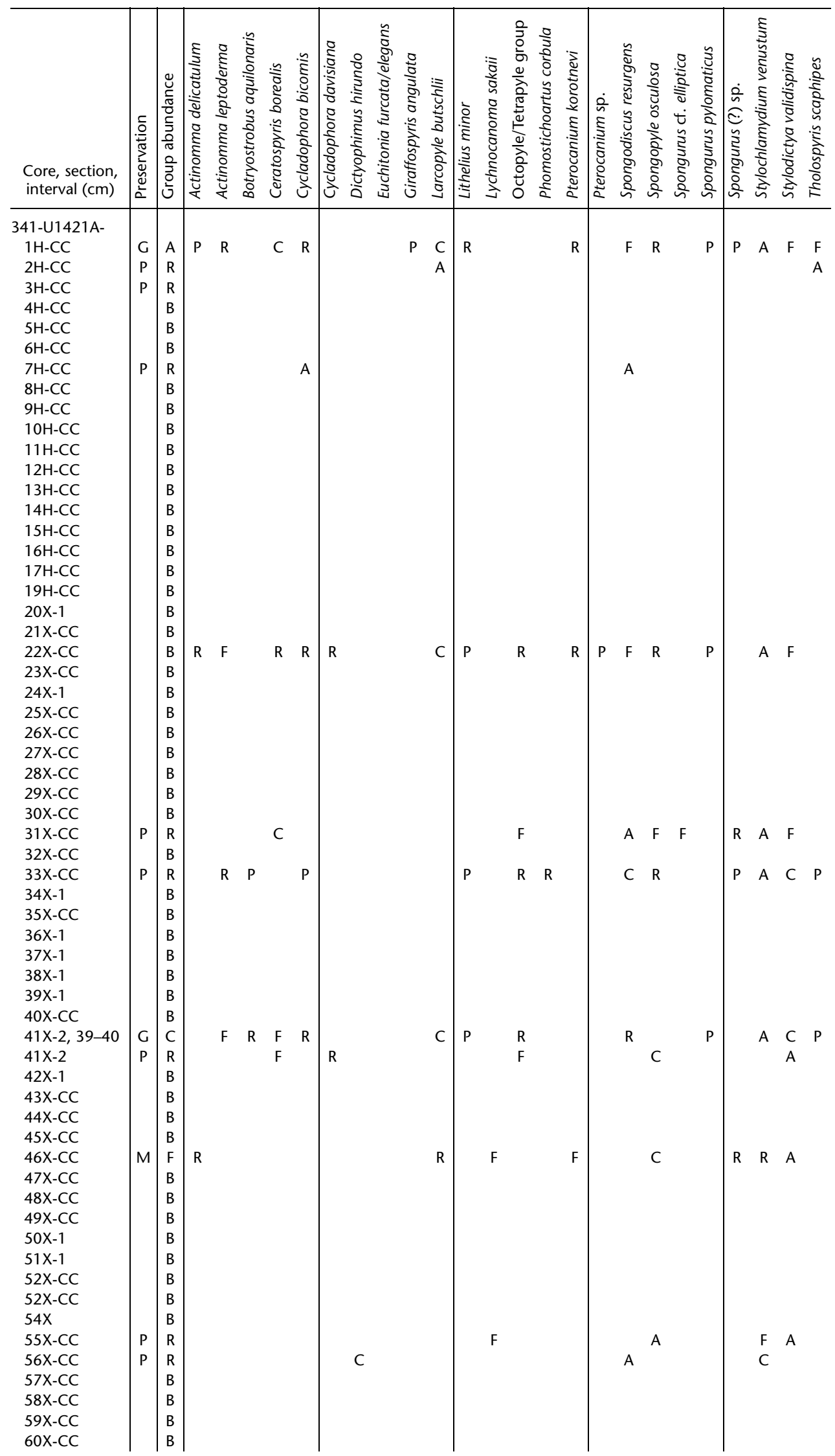

Proc. IODP | Volume 341

69 
Table T6 (continued).

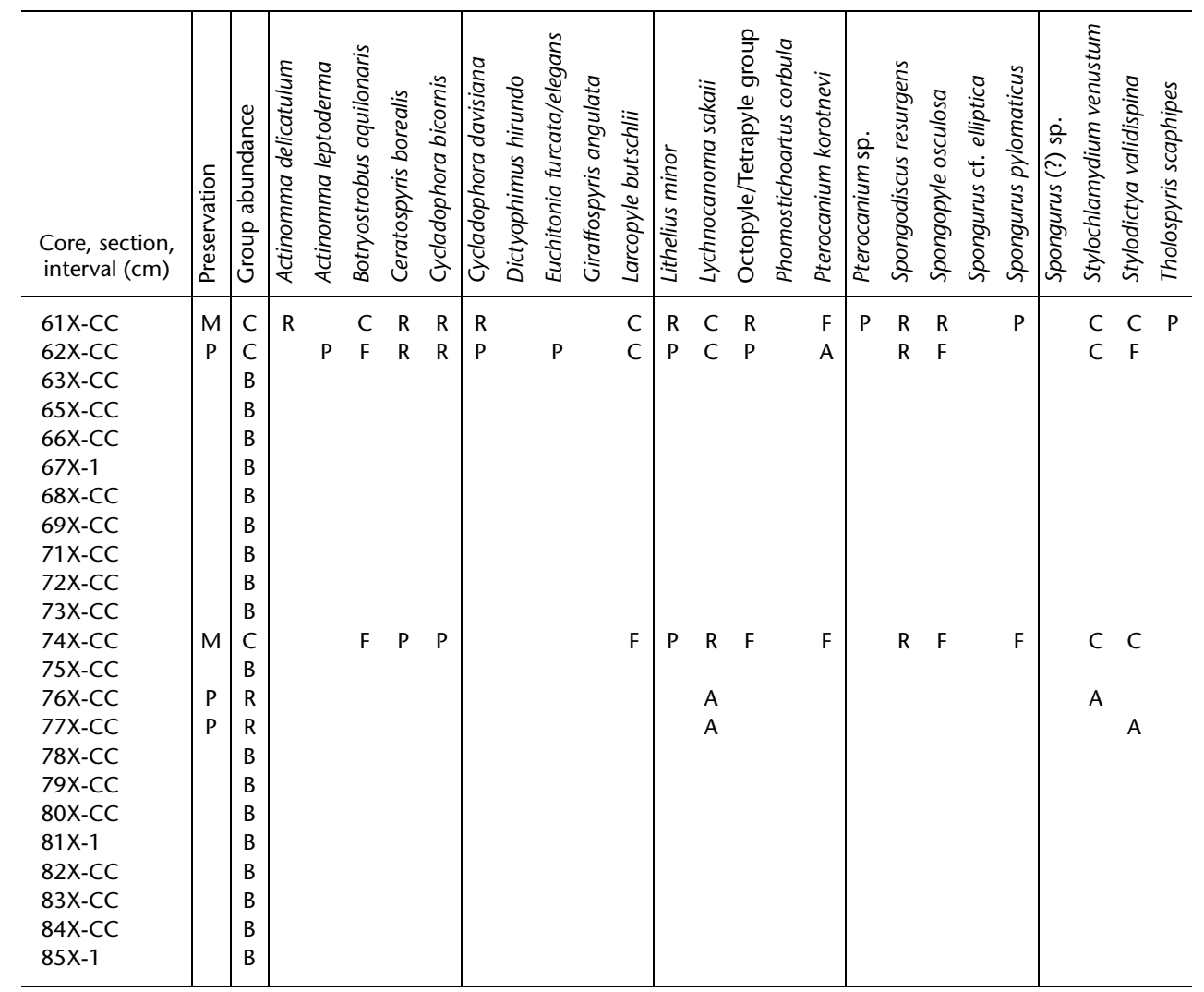

Preservation: $\mathrm{G}=$ good, $\mathrm{M}=$ moderate, $\mathrm{P}=$ poor. Abundance: $\mathrm{A}=$ abundant, $\mathrm{C}=$ common, $\mathrm{F}=\mathrm{few}, \mathrm{R}=\operatorname{rare}, \mathrm{P}=$ present, $\mathrm{B}=$ barren. This table is also available in .CSV. 
Table T7. Planktonic foraminifers, Site U1421.

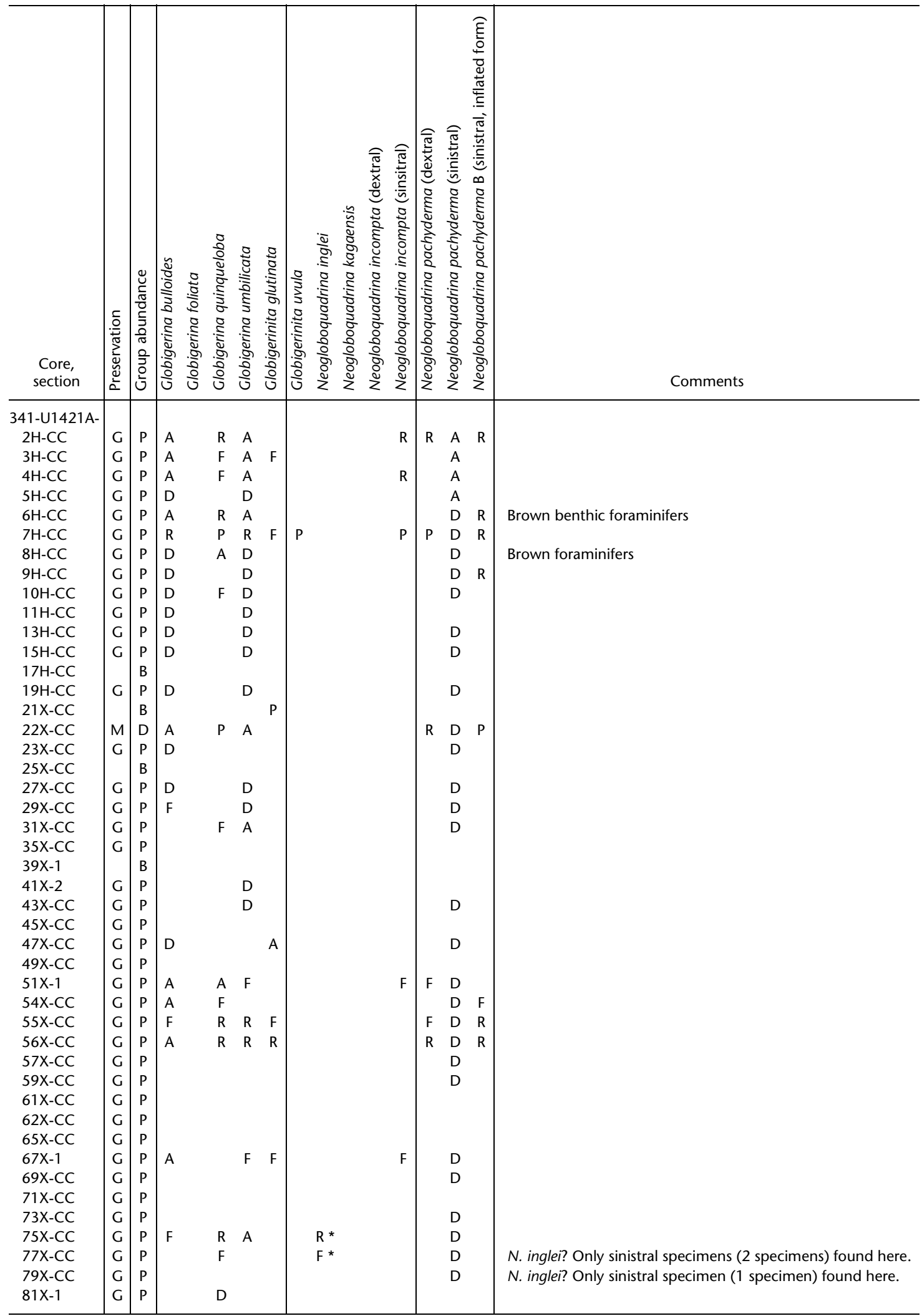

* = no datum events for sinistral $N$. inglei, and specimens found here require further inspection. Preservation: $G=g o o d, M=$ moderate. Abundance: $D=$ dominant, $A=$ abundant, $F=$ few, $R=$ rare, $P=$ present, $B=$ barren. This table is also available in .CSV. 


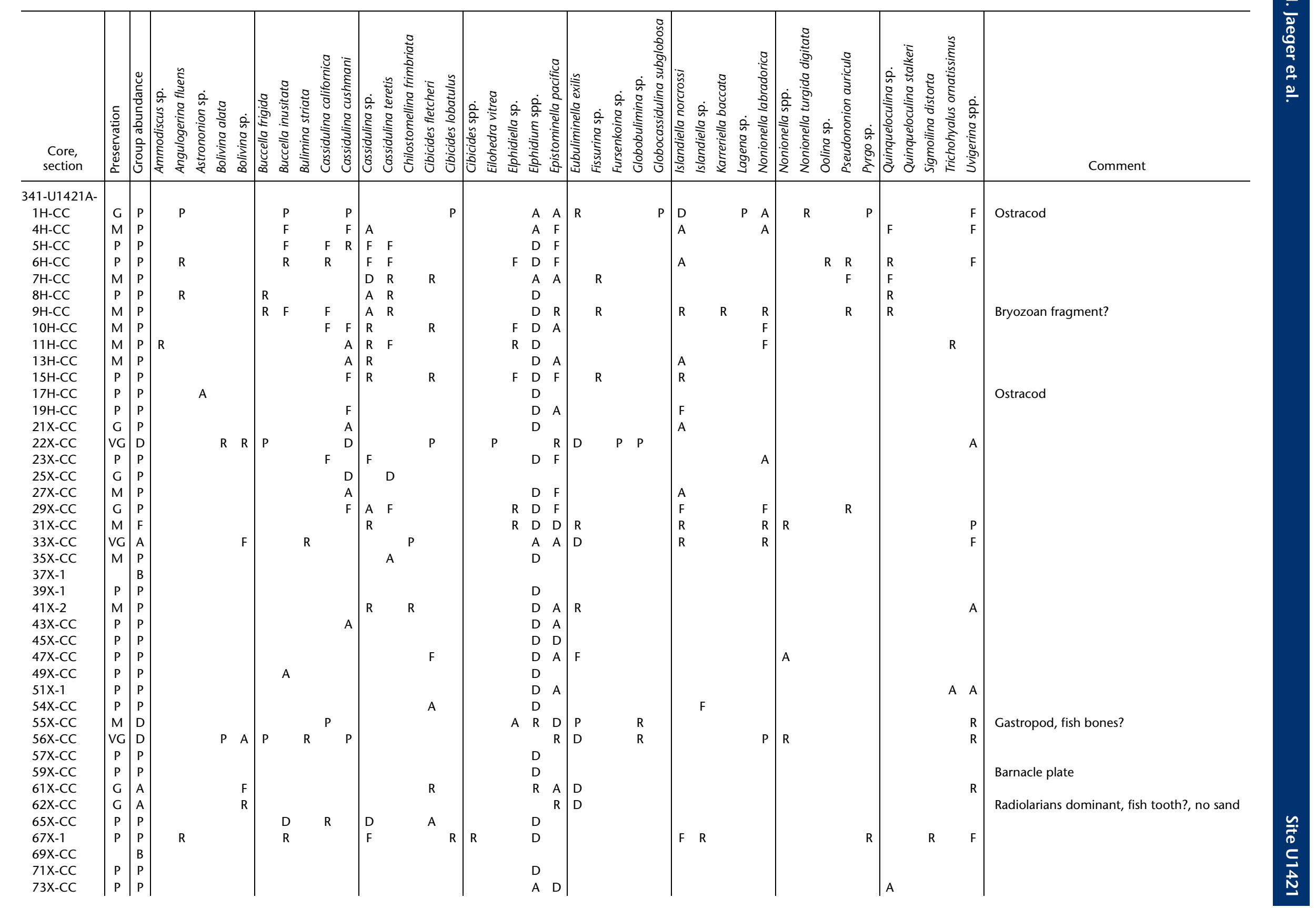




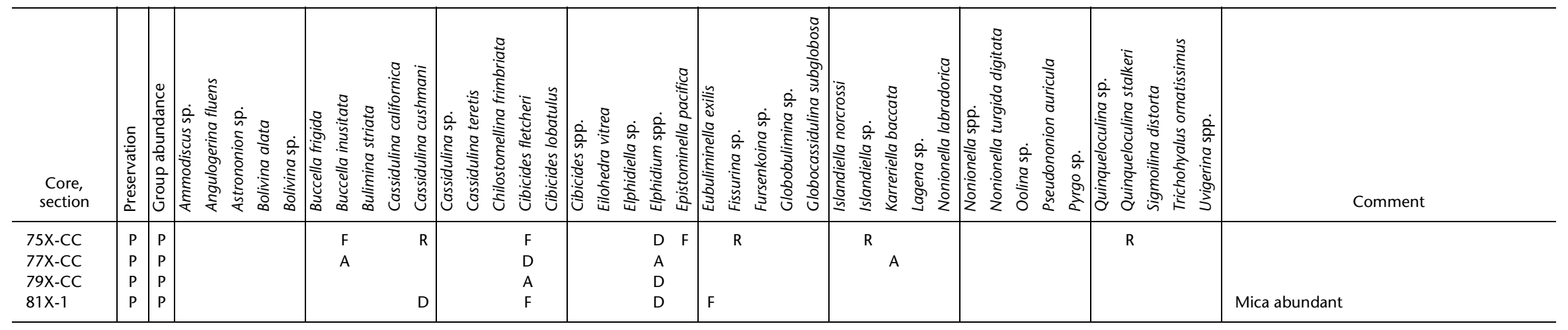

Preservation: $\mathrm{VG}=$ very good, $\mathrm{G}=$ good, $\mathrm{M}=$ moderate, $\mathrm{P}=$ poor. Abundance: $\mathrm{D}=$ dominant, $\mathrm{A}=$ abundant, $\mathrm{F}=$ few, $\mathrm{R}=\mathrm{rare}, \mathrm{P}=$ present, $\mathrm{B}=$ barren. This table is also available in .CSV. 
Table T9. Affine table, Site U1421.

\begin{tabular}{|c|c|}
\hline Core & Offset (m) \\
\hline \multicolumn{2}{|l|}{ 341-U1421A- } \\
\hline $1 \mathrm{H}$ & 0.04 \\
\hline $2 \mathrm{H}$ & -0.42 \\
\hline $3 \mathrm{H}$ & -0.42 \\
\hline $4 \mathrm{H}$ & 1.77 \\
\hline $5 \mathrm{H}$ & $1 \%$ recovery \\
\hline $6 \mathrm{H}$ & 1.77 \\
\hline 7H & 1.77 \\
\hline $8 \mathrm{H}$ & 1.77 \\
\hline $9 \mathrm{H}$ & 1.77 \\
\hline $10 \mathrm{H}$ & 1.77 \\
\hline $11 \mathrm{H}$ & 1.77 \\
\hline $12 \mathrm{H}$ & 1.77 \\
\hline $13 \mathrm{H}$ & 1.77 \\
\hline $14 \mathrm{H}$ & 1.77 \\
\hline $15 \mathrm{H}$ & 1.77 \\
\hline $16 \mathrm{H}$ & 1.77 \\
\hline $17 \mathrm{H}$ & 1.77 \\
\hline $18 \mathrm{H}$ & Only $3 \mathrm{~cm}$ \\
\hline $19 \mathrm{H}$ & 1.77 \\
\hline $20 x$ & 1.77 \\
\hline $21 x$ & 1.77 \\
\hline $22 x$ & 1.77 \\
\hline $23 x$ & 1.77 \\
\hline $24 X$ & 1.77 \\
\hline $25 x$ & 1.77 \\
\hline $26 \mathrm{X}$ & 1.77 \\
\hline $27 X$ & 1.77 \\
\hline $28 x$ & 1.77 \\
\hline $29 x$ & 1.77 \\
\hline $30 x$ & 1.77 \\
\hline $31 x$ & 1.77 \\
\hline $32 x$ & 1.77 \\
\hline $33 x$ & 1.77 \\
\hline $34 X$ & 1.77 \\
\hline $35 x$ & 1.77 \\
\hline $36 x$ & 1.77 \\
\hline $37 x$ & 1.77 \\
\hline $38 x$ & 1.77 \\
\hline $39 x$ & 1.77 \\
\hline $40 x$ & 1.77 \\
\hline $41 x$ & 1.77 \\
\hline $42 x$ & 1.77 \\
\hline $43 x$ & 1.77 \\
\hline $44 X$ & 1.77 \\
\hline $45 x$ & 1.77 \\
\hline $46 \mathrm{X}$ & 1.77 \\
\hline $47 X$ & 1.77 \\
\hline $48 x$ & 1.77 \\
\hline $49 x$ & 1.77 \\
\hline $50 x$ & 1.77 \\
\hline $51 X$ & 1.77 \\
\hline
\end{tabular}

\begin{tabular}{|c|c|}
\hline Core & Offset (m) \\
\hline $52 X$ & 1.77 \\
\hline $53 x$ & 1.77 \\
\hline $54 \mathrm{X}$ & 1.77 \\
\hline $55 x$ & 1.77 \\
\hline $56 \mathrm{X}$ & 1.77 \\
\hline $57 X$ & 1.77 \\
\hline $58 \mathrm{X}$ & 1.77 \\
\hline $59 x$ & 1.77 \\
\hline $60 x$ & 1.77 \\
\hline $61 x$ & 1.77 \\
\hline $62 X$ & 1.77 \\
\hline $63 x$ & 1.77 \\
\hline $64 X$ & 1.77 \\
\hline $65 x$ & 1.77 \\
\hline $66 \mathrm{X}$ & 1.77 \\
\hline $67 X$ & 1.77 \\
\hline $68 x$ & 1.77 \\
\hline $69 x$ & 1.77 \\
\hline $70 x$ & 1.77 \\
\hline $71 x$ & 1.77 \\
\hline $72 x$ & 1.77 \\
\hline $73 x$ & 1.77 \\
\hline $74 X$ & 1.77 \\
\hline $75 x$ & 1.77 \\
\hline $76 x$ & 1.77 \\
\hline $77 X$ & 1.77 \\
\hline $78 \mathrm{x}$ & 1.77 \\
\hline $79 x$ & 1.77 \\
\hline $80 x$ & 1.77 \\
\hline $81 X$ & 1.77 \\
\hline $82 X$ & 1.77 \\
\hline $83 x$ & 1.77 \\
\hline $84 X$ & 1.77 \\
\hline $85 x$ & 1.77 \\
\hline $\begin{array}{l}341-U 1421 \mathrm{~B}- \\
1 \mathrm{H}\end{array}$ & 0.11 \\
\hline $\begin{array}{l}341-U 1421 \mathrm{C}- \\
1 \mathrm{H}\end{array}$ & 0.00 \\
\hline $2 \mathrm{H}$ & Only $12 \mathrm{~cm}$ \\
\hline $3 \mathrm{H}$ & -0.15 \\
\hline $4 \mathrm{H}$ & -0.08 \\
\hline $5 \mathrm{H}$ & -0.23 \\
\hline $6 \mathrm{H}$ & -0.23 \\
\hline
\end{tabular}

Core: $\mathrm{H}=$ advanced piston corer, $\mathrm{X}=$ extended core barrel. Cores with very low recovery were not used for correlation purposes. 
Table T10. Splice tie points, Site U1421.

\begin{tabular}{lrrrlrrrr}
\hline $\begin{array}{c}\text { Hole, core, } \\
\text { section }\end{array}$ & $\begin{array}{c}\text { Tie point } \\
(\mathrm{cm})\end{array}$ & $\begin{array}{c}\text { Depth } \\
\text { CSF-A } \\
(\mathrm{m})\end{array}$ & $\begin{array}{c}\text { Depth } \\
\text { CCSF-A } \\
(\mathrm{m})\end{array}$ & \multicolumn{1}{c}{ Tie/Append } & $\begin{array}{c}\text { Hole, core, } \\
\text { section }\end{array}$ & $\begin{array}{c}\text { Tie point } \\
(\mathrm{cm})\end{array}$ & $\begin{array}{r}\text { Depth } \\
\text { CSF-A } \\
(\mathrm{m})\end{array}$ & $\begin{array}{c}\text { Depth } \\
\text { CCSF-A } \\
(\mathrm{m})\end{array}$ \\
\hline 341- & & & & & $341-$ & & & \\
U1421C-1H-5 & 109.83 & 7.10 & 7.10 & Tie to & U1421A-2H-1 & 72.13 & 7.52 & 7.10 \\
U1421A-2H-7 & 66.00 & 16.36 & $\mathbf{1 5 . 9 4}$ & Append & U1421A-3H-1 & 2.00 & 16.32 & $\mathbf{1 5 . 9 0}$ \\
U1421A-3H-3 & 53.52 & 19.84 & $\mathbf{1 9 . 4 1}$ & Tie to & U1421C-3H-2 & 5.97 & 19.56 & $\mathbf{1 9 . 4 1}$ \\
U1421C-3H-7 & 54.00 & 27.54 & $\mathbf{2 7 . 3 9}$ & Append & U1421C-4H-1 & 2.00 & 27.52 & $\mathbf{2 7 . 4 4}$ \\
U1421C-4H-1 & 47.93 & 27.98 & 27.90 & Tie to & U1421A-4H-1 & 32.96 & 26.13 & 27.90 \\
U1421A-4H-1 & 136.85 & 27.17 & 28.94 & Tie to & U1421C-5H-1 & 17.10 & 29.17 & 28.94 \\
\hline
\end{tabular}

Tie points in bold reflect tentative correlations. See text for details.

Table T11. Alternating field demagnetization steps used, Site U1421.

\begin{tabular}{cll}
\hline Hole & Cores undertaken & AF demagnetization steps $(\mathrm{mT})$ \\
\hline U1421A & 1H through 7H & $0,5,10,15,20$ \\
U1421A & 8 H through 78X & $0,10,20$ \\
U1421A & Section 62X-1 & $0,10,20,25,30$ \\
U1421A & 2H through 19H & $0,10,20$ \\
U1421B & All cores & 0,10 \\
U1421C & All cores & 0,10 \\
\hline
\end{tabular}

Table T12. Vertical seismic profile direct arrival times, Hole U1421A.

\begin{tabular}{ccccc}
\hline $\begin{array}{c}\text { Receiver depth } \\
(\mathrm{m} \text { WRF) }\end{array}$ & $\begin{array}{c}\text { Receiver depth } \\
(\mathrm{m} \text { WSF) }\end{array}$ & $\begin{array}{c}\text { Measured one-way } \\
\text { traveltime }(\mathrm{s})\end{array}$ & $\begin{array}{c}\text { Corrected one-way } \\
\text { traveltime }(\mathrm{s})\end{array}$ & $\begin{array}{c}\text { Corrected two-way } \\
\text { traveltime }(\mathrm{s})\end{array}$ \\
\hline 1018.7 & 284.7 & 0.63645 & 0.63900 & 1.27800 \\
1201.0 & 467.0 & 0.71996 & 0.72265 & 1.44530 \\
1265.0 & 531.0 & 0.75163 & 0.75436 & 1.50872 \\
1304.9 & 570.9 & 0.76808 & 0.77084 & 1.54168 \\
1371.0 & 637.0 & 0.79800 & 0.80079 & 1.60158 \\
1421.0 & 687.0 & 0.81787 & 0.82069 & 1.64138 \\
\hline
\end{tabular}

Measured traveltimes are times between the arrival of the pulse at a hydrophone located $2 \mathrm{~m}$ below the air guns and at the receiver in the borehole. Corrected traveltimes are times between sea level and the borehole receiver. 